Review

\title{
Development of Perovskite-Type Materials for Thermoelectric Application
}

\author{
Tingjun $\mathrm{Wu}^{1,2}$ and Peng Gao ${ }^{1,2, *(1)}$ \\ 1 CAS Key Laboratory of Design and Assembly of Functional Nanostructures, \\ and Fujian Key Laboratory of Nanomaterials, Fujian Institute of Research on the Structure of Matter, \\ Chinese Academy of Sciences, Fuzhou 350002, China; twu@fjirsm.ac.cn \\ 2 Laboratory of Advanced Functional Materials, Xiamen Institute of Rare Earth Materials, Haixi Institute, \\ Chinese Academy of Sciences, Xiamen 361021, China \\ * Correspondence: peng.gao@fjirsm.ac.cn; Tel.: +86-159-6081-6340
}

Received: 25 April 2018; Accepted: 9 June 2018; Published: 12 June 2018

\begin{abstract}
Oxide perovskite materials have a long history of being investigated for thermoelectric applications. Compared to the state-of-the-art tin and lead chalcogenides, these perovskite compounds have advantages of low toxicity, eco-friendliness, and high elemental abundance. However, because of low electrical conductivity and high thermal conductivity, the total thermoelectric performance of oxide perovskites is relatively poor. Variety of methods were used to enhance the TE properties of oxide perovskite materials, such as doping, inducing oxygen vacancy, embedding crystal imperfection, and so on. Recently, hybrid perovskite materials started to draw attention for thermoelectric application. Due to the low thermal conductivity and high Seebeck coefficient feature of hybrid perovskites materials, they can be promising thermoelectric materials and hold the potential for the application of wearable energy generators and cooling devices. This mini-review will build a bridge between oxide perovskites and burgeoning hybrid halide perovskites in the research of thermoelectric properties with an aim to further enhance the relevant performance of perovskite-type materials.
\end{abstract}

Keywords: perovskite; thermoelectric; generator; cooler

\section{Introduction}

\subsection{Thermoelectrics (TE)}

Thermoelectric effect includes Seebeck effect and Peltier effect. The Seebeck effect denotes the process that converts temperature gradient directly to electricity, which can be illustrated by the working principle of a thermoelectric generator (Figure 1A). In contrast, the Peltier effect can convert electrical energy to a temperature gradient, which leads to thermoelectric cooling device. Thermoelectric performance of a material is evaluated by the dimensionless thermoelectric figure of merit (ZT),

$$
\mathrm{ZT}=\frac{\mathrm{S}^{2} \sigma}{\mathrm{K}} \mathrm{T}
$$

where $\mathrm{S}\left(\mathrm{V} \cdot \mathrm{K}^{-1}\right)$ is Seebeck coefficient, $\sigma\left(\mathrm{S} \cdot \mathrm{m}^{-1}\right)$ is electrical conductivity, $\mathrm{k}\left(\mathrm{W} \cdot \mathrm{m}^{-1} \cdot \mathrm{K}^{-1}\right)$ is thermal conductivity, and $\mathrm{T}(\mathrm{K})$ is absolute temperature. $\mathrm{S}^{2} \sigma$ is defined as the thermoelectric power factor. The thermoelectric energy conversion efficiency and the maximum cooling temperature for Peltier devices are dependent on the value of ZT [1]. 

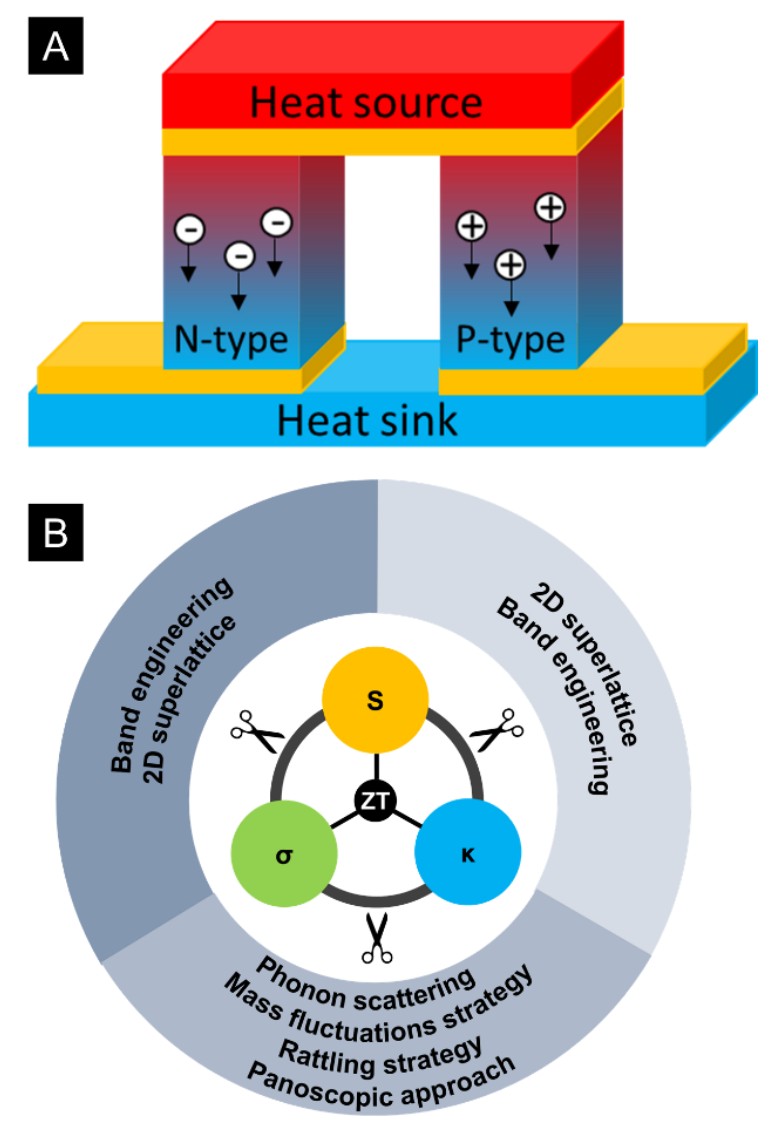

Figure 1. (A) Schematic of Seebeck effect; (B) schematic of interdependent relationship of Seebeck coefficient, electrical conductivity, and thermal conductivity, and the strategies to decouple their interdependency.

The maximum efficiency ( $\eta$ ) of a thermoelectric device is defined as the quotient of the energy provided to the load $(\mathrm{W})$ and the heat energy consumed at the hot junction $(\mathrm{Q})$. It is a function of ZT as well as the temperature of the hot and cold side $\left(\mathrm{T}_{\mathrm{H}}, \mathrm{T}_{\mathrm{C}}\right)$, as shown in the equation

$$
\eta=\frac{W}{Q}=\frac{T_{H}-T_{C}}{T_{H}} \frac{\sqrt{1+Z T}-1}{\sqrt{1+Z T}+\frac{T_{H}}{T_{C}}}
$$

Therefore, to enhance the thermoelectric properties of materials, namely increase the ZT value, the materials should have high Seebeck coefficient, high electrical conductivity, and low thermal conductivity [1-4].

However, simply enhancing the ZT value of TE materials is non-trivial, since the parameters are interrelated. One direct way to enhance the electrical conductivity of semiconductors is to increase the carrier concentration, as shown in the equation:

$$
\sigma=\mathrm{e}\left(\mathrm{n}_{\mathrm{e}} \mu_{\mathrm{e}}+\mathrm{n}_{\mathrm{h}} \mu_{\mathrm{h}}\right)
$$

where $e$ is the elementary charge; $n_{e}$ and $n_{h}$ are the carrier concentrations of electrons and holes, respectively; $\mu_{\mathrm{e}}$ and $\mu_{\mathrm{h}}$ are the carrier mobility of electrons and holes, respectively. 
However, the Seebeck coefficient for metal or degenerate semiconductor is defined by the equation:

$$
\mathrm{S}=\frac{8 \pi^{2} \mathrm{k}_{\mathrm{B}}^{2}}{3 \mathrm{eh}^{2}} \mathrm{~m}^{*} \mathrm{~T}\left(\frac{\pi}{3 \mathrm{n}}\right)^{\frac{2}{3}}
$$

where $k_{\mathrm{B}}$ is Boltzmann constant, $\mathrm{h}$ is Planck's constant, $\mathrm{m}^{*}$ is the effective mass of the charge carrier, $\mathrm{T}$ is absolute temperature, and $\mathrm{n}$ is the carrier concentration. According to Equation (4), $\mathrm{S}$ would decrease when increasing the carrier concentration.

The thermal conductivity is linked to electron and phonon contributions. The electronic thermal conductivity (electron contributions, $\mathrm{k}_{\mathrm{e}}$ ) can be expressed according to Wiedemann-Franz law:

$$
\mathrm{K}_{\mathrm{e}}=\mathrm{L} \cdot \sigma \cdot \mathrm{T}
$$

where $\mathrm{L}$ is the Lorentz number, and $\mathrm{T}$ is absolute temperature. Thus, it is directly related to electrical conductivity. As a consequence, the TE materials have an optimum carrier concentration to improve ZT value. The interdependent relationship was of $\sigma, S$, and $k$ were shown in Figure $1 \mathrm{~B}$, the ZT value was determined by $\sigma, S$, and $k$, which was interconnected shown as the inner circle. To further enhance the ZT value, it is inevitable to decouple the interrelationship between the parameters. In inorganic TE materials, multiple ways have been applied to enhance the ZT value. For example, a phonon scattering mechanism was introduced by processing of superlattices and by accessing thermodynamically stable phase separation to suppress the lattice thermal conductivity without the expense of electrical conductivity [5-7]. Additionally, mass fluctuation strategy, rattling strategy, and the panoscopic approach were also used to decouple the relationship between $\sigma$ and $\mathrm{k}$ [7-12]. Energy filtering effect is also normally used to decouple the electrical conductivity and Seebeck coefficient, in which an energy barrier was introduced in the TE materials by nanocomposites or grain boundaries. This energy barrier would filter out low energy carriers and let high energy carriers pass. As a result, the Seebeck coefficient can be improved without suppressing the electrical conductivity [13-16]. Additionally, the band engineering, which is used to decouple the Seebeck coefficient and electrical conductivity, also includes degeneration of multiple valleys, electronic resonance states, synergistic nanostructuring, and highly mismatched isoelectronic doping. Furthermore, 2D superlattice can also be used to decouple $\mathrm{S}$ and $\sigma[8-10,17,18]$. These strategies were shown in the outer circle of Figure 1B.

TE devices can serve as generator and cooler and be used to recycle waste heat and manage temperature, respectively. Moreover, TE devices have advantages of no vibration, no noise, and highly reliable because they are solid-state devices without moving parts. In our previous studies, thick thermoelectric tellurium (Te) [19] and lead telluride (PbTe) [20] films were synthesized by electrodeposition with high film growth rate. The combination of electrochemical deposition of compound semiconductors with standard integrated circuit technique enables the fabrication of thermoelectric microdevices, which has a more compact size and a capability to handle a wider range of thermal and power management [21-23].

Materials, which are candidates for fabricating TE devices, can be classified as shown in Figure 2. Materials such as organic [5,6,24-32], hybrid perovskites [33-35] and the group $\mathrm{V}$ chalcogenides $[3,7,10-12,36]$ are suitable for TE application at the near-room-temperature range. In addition, TE materials—such as the group IV chalcogenides [10,11,20,36], group III-V compounds $[10,17,36]$, group IV-based materials $[7,10,12,36]$, half-Heusler alloys $[3,7,9,11]$, skutterudites [3,11,37], Zintl compounds [3,9,12,37], and clathrates [9,11]—are applicable at the middle temperature (about 400-900 K) range. Furthermore, materials-like rare earth chalcogenides [36], oxide perovskites [38-40], borides [36], and metal oxides [36] — can be used at a high temperature $(>1000 \mathrm{~K})$ range. However, normally there is no clear operation temperature boundary for each type of TE materials, for instance, rare earth chalcogenides, group III-V compounds, oxide perovskites materials, borides and metal oxides can be applied in a vast range of temperature depending on specific compounds $[10,17,36,38-40]$. The inorganic materials are the most well-studied TE 
materials [3,7,10-12,36,41]. We have studied the thermoelectric properties of PbTe films [20] and silver telluride nanofibers [41]. Additionally, Te nanostructures including nanowire [42], nanotree [42], and nanorice [43] were synthesized, which can be used to be embedded into other TE materials as nanocomposite [44-46] or converted to metal tellurides through cation exchange reaction [47,48]. Metal oxide materials, other than oxide perovskite materials, were investigated for TE application. For example, $\mathrm{NaCo}_{2} \mathrm{O}_{4}$ was reported to have an in-plane $\mathrm{S}$ of $100 \mu \mathrm{V} \cdot \mathrm{K}^{-1}$ and $\sigma$ of $5000 \mathrm{~S} \cdot \mathrm{cm}^{-1}$ at $300 \mathrm{~K}$ [49], $\mathrm{Bi}_{2.2} \mathrm{Sr}_{1.8} \mathrm{Co}_{2} \mathrm{O}_{9}$ achieved a $\mathrm{ZT}$ value of 0.19 at $973 \mathrm{~K}$ with $\mathrm{S}$ of $\sim 150 \mu \mathrm{V} \cdot \mathrm{K}^{-1}, \sigma$ of $\sim 82 \mathrm{~S} \cdot \mathrm{cm}^{-1}$ and $\mathrm{K}$ of $\sim 0.9 \mathrm{~W} \cdot \mathrm{m}^{-1} \cdot \mathrm{K}^{-1}$ [50], $\mathrm{Ca}_{3} \mathrm{Co}_{4} \mathrm{O}_{9}$ showed a $\mathrm{S}$ of $\sim 125 \mu \mathrm{V} \cdot \mathrm{K}^{-1}$ and $\sigma$ of $\sim 28 \mathrm{~S} \cdot \mathrm{cm}^{-1}$ at $300 \mathrm{~K}$ [51], $\mathrm{Zn}_{0.96} \mathrm{Al}_{0.02} \mathrm{Ga}_{0.02} \mathrm{O}$ reached a $\mathrm{ZT}$ value 0.65 at $1247 \mathrm{~K}$ with $\mathrm{S}$ of $230 \mu \mathrm{V} \cdot \mathrm{K}^{-1}, \sigma$ of $\sim 400 \mathrm{~S} \cdot \mathrm{cm}^{-1}$ and $\mathrm{K}$ of $5 \mathrm{~W} \cdot \mathrm{m}^{-1} \cdot \mathrm{K}^{-1}$ because of a bulk nanocomposite structure [52]. In the past decade, many efforts have been put into the investigation of organic thermoelectric materials [25-29]. Moreover, the hybrid perovskites started to draw attention for TE application [35]. In this review, we are going to focus on oxide and hybrid perovskite materials.

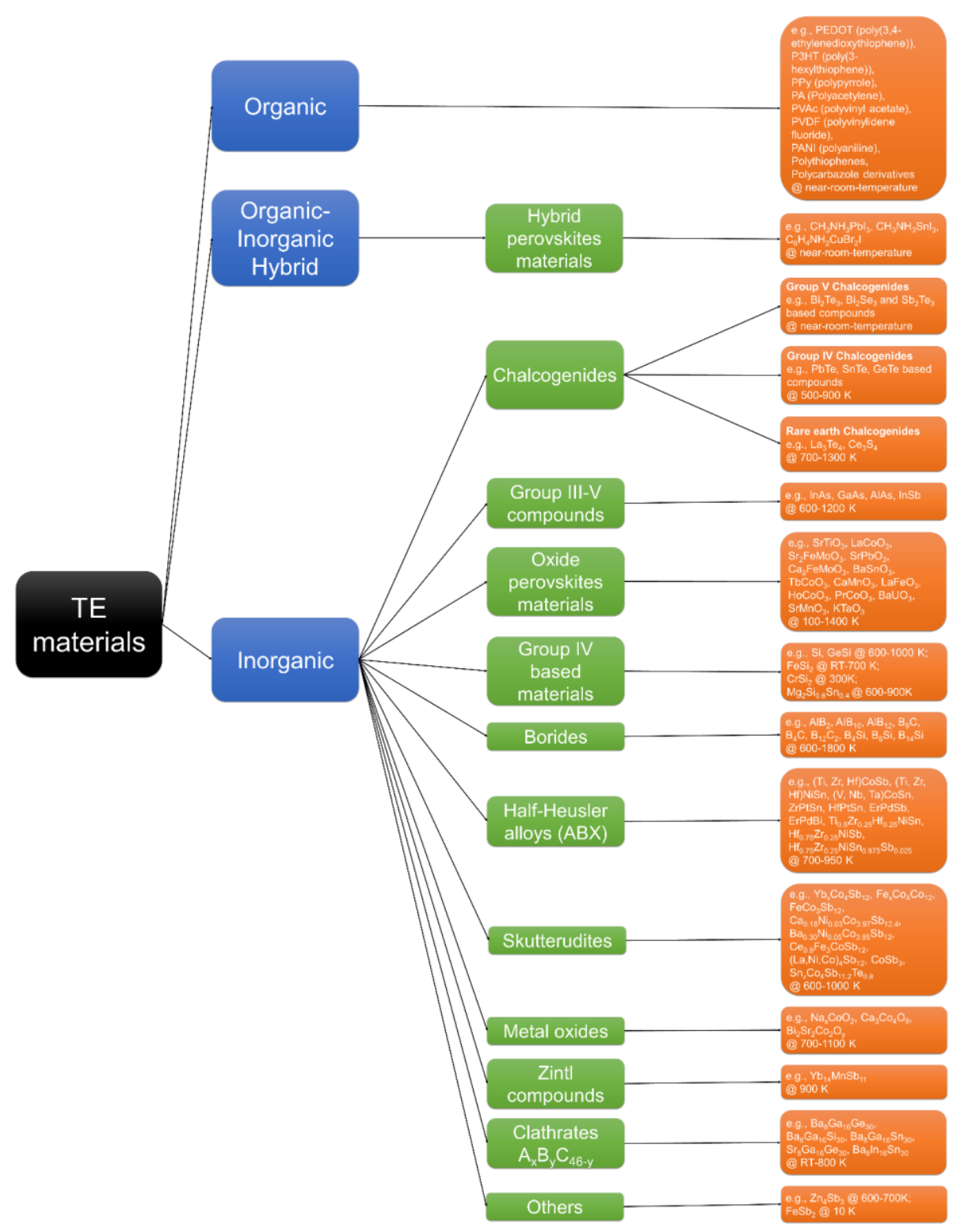

Figure 2. Thermoelectric materials studied through experimentation or calculation. 


\subsection{Perouskite Materials}

Perovskite materials are any materials have the same type of crystal structure as calcium titanium oxide $\left(\mathrm{CaTiO}_{3}\right)$. The general chemical formula for perovskites compounds is $\mathrm{ABX}_{3}$. $\mathrm{A}$ and $\mathrm{B}$ are two cations of very different sizes, and $\mathrm{X}$ is an anion that bonds to both [53]. Perovskite materials have a variety of applications, such as photovoltaics [53,54], light emitting diodes, thin film transistors, and so on [55]. Oxide perovskite materials have a long history of being applied for TE materials, while hybrid perovskite materials have just begun to be studied for TE applications in recent years.

The most common stable crystal phases of perovskite materials are orthorhombic, tetragonal, and cubic phases as shown in Figure 3 [56]. The stable phase of perovskites materials is determined by both ion size and temperature. For example, the orthorhombic phase of $\mathrm{MAPbI}_{3}$ is the low-temperature state and can keep its structure stable up to $165 \mathrm{~K}$. With increased temperature, $\mathrm{MAPbI}_{3}$ undergoes a phase-transition to the tetragonal phase owing to the disordering of $\mathrm{MA}^{+}$. When temperature further reaches $327 \mathrm{~K}$, highly disordered $\mathrm{MA}^{+}$cations give rise to the high-symmetry state of $\mathrm{MAPbI}_{3}$ which has the cubic phase. The packing densities of the three phases follow the trend: $c-\mathrm{MAPbI}_{3}>\mathrm{o}-\mathrm{MAPbI}$ $>\mathrm{t}-\mathrm{MAPbI}_{3}$, where the packing density of $\mathrm{MAPbI}_{3}$ increases as the crystal symmetry and temperature increases [56].

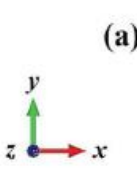

(a)
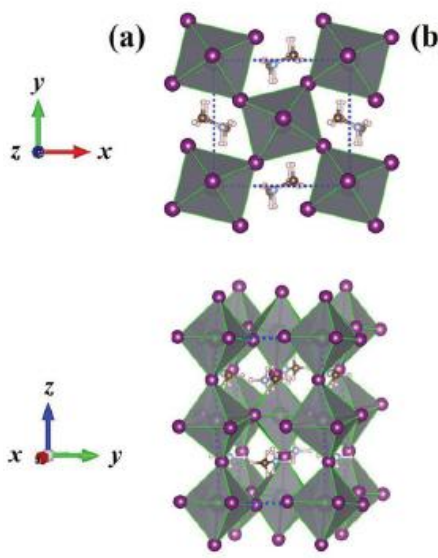

Orthorhombic (b)
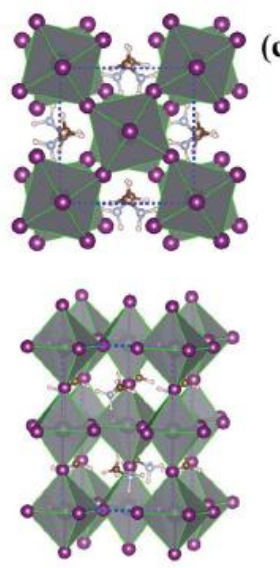

Tetragonal (c)
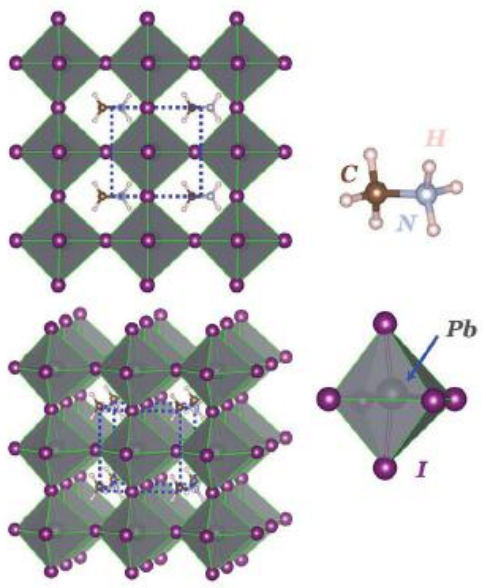

Cubic

Figure 3. Atomistic configurations of (a) orthorhombic; (b) tetragonal; and (c) cubic phases of perovskite materials. Reproduced with permission [56]. Copyright 2016, Advanced Functional Materials.

In this review, we will focus on the application of perovskite materials in thermoelectrics, which has not been systematically reviewed. The perovskite materials used for TE application can be classified into oxide and hybrid perovskites materials. The elements used in perovskite materials are summarized in Figure 4. The elements in the red box were used for A-site, the ones in the pink box were used for A-site doping, and the ones in the brown box were used for both A-site and A-site doping materials. The elements in the blue box were used for B-site, the ones in green box were used for B-site doping, and the ones in the cyan box were used for both B-site and B-site doping. Compared to the traditional materials used for TE application, such as metal chalcogenide materials like $\mathrm{Bi}_{2} \mathrm{Te}_{3}$ and $\mathrm{PbTe}$, perovskite materials are less capitally expensive and can be processed by low energy cost methods, especially for hybrid perovskite materials, and can be used for flexible TE devices. The reported TE data about perovskite materials were shown in Table 1. 
Table 1. Literature data about TE properties of perovskite material.

\begin{tabular}{|c|c|c|c|c|c|c|c|}
\hline Ref. & Materials & $\begin{array}{c}\text { Seebeck } \\
\left(\mu \mathrm{V} \cdot \mathrm{K}^{-1}\right)\end{array}$ & $\begin{array}{l}\text { Electrical Conductivity } \\
\left(\mathrm{S} \cdot \mathrm{cm}^{-1}\right)\end{array}$ & $\begin{array}{l}\text { Thermal Conductivity } \\
\left(\mathrm{W} \cdot \mathrm{m}^{-1} \cdot \mathrm{K}^{-1}\right)\end{array}$ & $\begin{array}{c}\text { Power Factor } \\
\left(\mu \mathrm{W} \cdot \mathrm{K}^{-2} \cdot \mathrm{m}^{-1}\right)\end{array}$ & $\mathrm{ZT}$ & Measure Temp. (K) \\
\hline [38] & La-Doped $\mathrm{SrTiO}_{3}$ & -260 & & & & & 298 \\
\hline [57] & $\mathrm{Sr}_{0.85} \mathrm{La}_{0.15} \mathrm{TiO}_{3}$ & 175 & 400 & 3 & & 0.28 & 873 \\
\hline [58] & $\mathrm{SrTiO}_{3}$ & 210 & 250 & & 200 & & 300 \\
\hline [59] & reduced graphene oxide $-\mathrm{SrTiO}_{3}$ & -380 & 30 & & & 0.09 & 760 \\
\hline [40] & $\mathrm{Sr}_{0.875} \mathrm{Pr}_{0.125} \mathrm{TiO}_{3}$ & -80 & 3700 & & & 0.4 & 323 \\
\hline [60] & $\mathrm{La}$-doped $\mathrm{SrTiO}_{3}$ & 980 & & & 0.39 & & 298 \\
\hline [61] & $\mathrm{Sr}_{0.9} \mathrm{La}_{0.1} \mathrm{TiO}_{3}$ & -250 & & & & & 1000 \\
\hline$[62]$ & $\stackrel{\mathrm{Sr}_{0.9} \mathrm{Dy}_{0.1} \mathrm{TiO}_{3}}{\mathrm{R}}$ & -160 & 500 & 2.7 & & 0.22 & 573 \\
\hline [63] & $\mathrm{Sr}_{0.95} \mathrm{La}_{0.05} \mathrm{TiO}_{3}$ & 250 & 150 & 4.2 & 800 & 0.15 & 780 \\
\hline [64] & $\mathrm{Sr}_{0.9} \mathrm{La}_{0.1} \mathrm{TiO}_{3}$ & -225 & 300 & 3.2 & & 0.21 & 750 \\
\hline [65] & La-doped $\mathrm{SrTiO}_{3}$ & -300 & 80 & 3.1 & & 0.27 & 1073 \\
\hline \multirow[t]{2}{*}{ [66] } & $\mathrm{Sr}_{0.96} \mathrm{Ce}_{0.04} \mathrm{TiO}_{3}$ & -65 & & & & & 300 \\
\hline & $\mathrm{Sr}_{0.98} \mathrm{La}_{0.02} \mathrm{TiO}_{3}$ & -138 & & & & & 300 \\
\hline [67] & $\mathrm{Sr}_{2} \mathrm{CoTiO}_{6}$ & 60 & 10 & & & & 1200 \\
\hline [68] & $\operatorname{Sr}\left(\mathrm{Ti}_{0.8} \mathrm{Nb}_{0,2}\right) \mathrm{O}_{3}$ & -200 & & 3.5 & 1300 & 0.37 & 1000 \\
\hline [69] & $\mathrm{BaNb}_{0.01} \mathrm{Ti}_{0.99} \mathrm{O}_{3}$ & -640 & & & & & 290 \\
\hline [70] & $\mathrm{BaTiO}_{3}$ & -550 & & & & & 300 \\
\hline [71] & $\mathrm{Sr}_{0.9} \mathrm{Y}_{0.1} \mathrm{TiO}_{3}$ & -130 & & & 120 & & 420 \\
\hline [72] & $\mathrm{Ba}_{0.3} \mathrm{Sr}_{0.6} \mathrm{La}_{0.1} \mathrm{TiO}_{3}$ & -110 & & 4.4 & & 0.13 & 420 \\
\hline [73] & $\mathrm{Sr}_{0.45} \mathrm{Ca}_{0.45} \mathrm{La}_{0.1} \mathrm{TiO}_{3}$ & -195 & 250 & 3.7 & & 0.22 & 850 \\
\hline [74] & $\mathrm{Sr}_{0.98} \mathrm{La}_{0.02} \mathrm{TiO}_{3}$ & -260 & 500 & 11 & & 0.09 & 298 \\
\hline [75] & $\mathrm{SrTiO}_{3} / \mathrm{SrTi}_{0.8} \mathrm{Nb}_{0.2} \mathrm{O}_{3} / \mathrm{SrTiO}_{3}$ & -850 & 1400 & 12 & & 2.4 & 300 \\
\hline [76] & $\operatorname{Sr}\left(\mathrm{Ti}_{0.8} \mathrm{Nb}_{0.2}\right) \mathrm{O}_{3}$ & & & 3 & & 0.35 & 1000 \\
\hline [77] & $\mathrm{Sr}_{0.2} \mathrm{Eu}_{0.8} \mathrm{Ti}_{0.8} \mathrm{Nb}_{0.2} \mathrm{O}_{3}$ & 170 & 0.5 & & & & 1000 \\
\hline [78] & $\mathrm{SrTi}_{0.9} \mathrm{Ta}_{0.1} \mathrm{O}_{3}$ & -175 & 300 & 4.4 & & 0.17 & 752 \\
\hline \multirow[t]{2}{*}{ [79] } & $\mathrm{BaTiO}_{3}$ & -620 & 0.17 & & & & 300 \\
\hline & $\mathrm{PbTiO}_{3}$ & 110 & & & & & 300 \\
\hline \multirow[t]{2}{*}{ [80] } & $\mathrm{BaTiO}_{3}$ & 110 & & & & & 300 \\
\hline & $\mathrm{SrTiO}_{3}$ & 100 & & & & & 300 \\
\hline [81] & $\mathrm{SrTiO}_{3}$ & -500 & & & & & 300 \\
\hline [82] & $\mathrm{Nb}$-doped $\mathrm{SrTiO}_{3}$ & -540 & & & & & 1200 \\
\hline [83] & $\mathrm{Sr}_{0.95} \mathrm{La}_{0.05} \mathrm{Ti}_{0.98} \mathrm{Mn}_{0.02} \mathrm{O}_{3}$ & -150 & 833 & 3.9 & 20 & 0.15 & 300 \\
\hline [84] & $\mathrm{La}_{0.25} \mathrm{Sr}_{0.75} \mathrm{TiO}_{3}$ & 450 & & & & & 300 \\
\hline [85] & n-type $\mathrm{SrTiO}_{3}$ & 300 & & & & 0.7 & 1400 \\
\hline \multirow{2}{*}[86]{} & $\mathrm{Sr}_{2} \mathrm{TiFeO}_{6}$ & 280 & 1.2 & & 10 & & 1130 \\
\hline & $\mathrm{Sr}_{2} \mathrm{TiCoO}_{6}$ & 60 & 20 & & 5.4 & & 750 \\
\hline [39] & $\mathrm{Ba}_{0.25} \mathrm{Sr}_{1.75} \mathrm{FeTiO}_{6}$ & 800 & & & 15 & & 1123 \\
\hline
\end{tabular}


Table 1. Cont.

\begin{tabular}{|c|c|c|c|c|c|c|c|}
\hline Ref. & Materials & $\begin{array}{c}\text { Seebeck } \\
\left(\mu \mathrm{V} \cdot \mathrm{K}^{-1}\right)\end{array}$ & $\begin{array}{c}\text { Electrical Conductivity } \\
\left(\mathrm{S} \cdot \mathrm{cm}^{-1}\right)\end{array}$ & $\begin{array}{l}\text { Thermal Conductivity } \\
\left(\mathrm{W} \cdot \mathrm{m}^{-1} \cdot \mathrm{K}^{-1}\right)\end{array}$ & $\begin{array}{c}\text { Power Factor } \\
\left(\mu \mathrm{W} \cdot \mathrm{K}^{-2} \cdot \mathrm{m}^{-1}\right)\end{array}$ & ZT & Measure Temp. (K) \\
\hline [87] & $\mathrm{Sr}_{2} \mathrm{TiMoO}_{6}$ & -10.8 & 960 & & 11 & & 1223 \\
\hline$[88]$ & $\mathrm{SrTiO}_{3}$ & -150 & & & & & 1000 \\
\hline \multirow[t]{2}{*}{ [89] } & $\mathrm{SrTi}_{0.5} \mathrm{Co}_{0.5} \mathrm{O}_{3}$ & 200 & & & & 1.36 & 800 \\
\hline & $\left(\mathrm{Tb}_{0.1} \mathrm{Ca}_{0.9}\right) \mathrm{MnO}_{3}$ & -140 & -0.18 & & & 0.13 & 950 \\
\hline \multirow{2}{*}[90]{} & $\left(\mathrm{Ho}_{0.1} \mathrm{Ca}_{0.9}\right) \mathrm{MnO}_{3}$ & -110 & -0.18 & & & 0.08 & 950 \\
\hline & $\left(\mathrm{Y}_{0.1} \mathrm{Ca}_{0.9}\right) \mathrm{MnO}_{3}$ & -130 & -0.2 & & & 0.15 & 950 \\
\hline [91] & $\left(\mathrm{Ca}_{0.9} \mathrm{Bi}_{0.1}\right) \mathrm{MnO}_{3}$ & 80 & 10 & 4 & & 0.095 & 1173 \\
\hline [92] & $\mathrm{Sr}_{0.9} \mathrm{Ce}_{0.1} \mathrm{MnO}_{3}$ & 180 & 100 & & & & 1273 \\
\hline [93] & $\mathrm{CaMnO}_{3}$ & -520 & & & & & 667 \\
\hline [94] & $\mathrm{Ca}_{0.85} \mathrm{Pr}_{0.15} \mathrm{MnO}_{2.98}$ & -130 & 111 & 1.5 & & 0.17 & 1100 \\
\hline [95] & $\mathrm{Ca}_{0.9} \mathrm{Yb}_{0.1} \mathrm{MnO}_{3}$ & -150 & 133 & 1.6 & & 0.16 & 970 \\
\hline [96] & $\mathrm{Ca}_{0.8} \mathrm{Dy}_{0.2} \mathrm{MnO}_{3}$ & -135 & 270 & & 510 & & 1073 \\
\hline [97] & $\operatorname{Pr}_{0.3} \mathrm{Sr}_{0.7} \mathrm{MnO}_{3}$ & -75 & 250 & 1.6 & & 0.085 & 1073 \\
\hline [98] & $\mathrm{Sm}_{0.25} \mathrm{Ca}_{0.75} \mathrm{MnO}_{3}$ & -380 & & & & & 65 \\
\hline [99] & $\mathrm{CaMn}_{0.88} \mathrm{Mo}_{0.12} \mathrm{O}_{3}$ & -240 & 0.011 & & & & 100 \\
\hline [100] & $\mathrm{YNi}_{0.3} \mathrm{Mn}_{0.7} \mathrm{O}_{3}$ & 90 & & & & & 357 \\
\hline [101] & $\mathrm{SrMnO}_{3}$ & -110 & 50 & & & & 300 \\
\hline [102] & $\begin{array}{c}\mathrm{CaMn}_{0.85} \mathrm{Mo}_{0.15} \mathrm{O}_{3} \\
\left(\mathrm{Sm}_{0.2} \mathrm{Ca}_{0.8} \mathrm{MnO}_{3}, \mathrm{Pr}_{0.15} \mathrm{Sr}_{0.85} \mathrm{MnO}_{3}\right)\end{array}$ & -270 & $10^{-4}$ & 0.6 & & & 80 \\
\hline [103] & $\mathrm{Ca}_{0.96} \mathrm{Bi}_{0.04} \mathrm{MnO}_{3}$ & -170 & 66.7 & 3.6 & 300 & 0.086 & 1000 \\
\hline \multirow{2}{*}{ [104] } & $\mathrm{CaMn}_{0.96} \mathrm{Mo}_{0.04} \mathrm{O}_{3}$ & -90 & & 3.4 & & 0.012 & 270 \\
\hline & $\mathrm{CaMn}_{0.94} \mathrm{Ru}_{0.06} \mathrm{O}_{3}$ & -140 & & 5.4 & & 0.0085 & 330 \\
\hline \multirow{2}{*}{ [105] } & $\mathrm{CaMn}_{0.98} \mathrm{Ta}_{0.02} \mathrm{O}_{3}$ & -190 & 29 & & & 0.05 & 1000 \\
\hline & $\mathrm{CaMn}_{0.98} \mathrm{Nb}_{0.02} \mathrm{O}_{3}$ & -205 & & & & & 1000 \\
\hline [106] & $\mathrm{Ca}_{0.4} \mathrm{Sr}_{0.6} \mathrm{Mn}_{0.96} \mathrm{Mo}_{0.04} \mathrm{O}_{3}$ & -110 & 50 & & & & 220 \\
\hline [107] & $\mathrm{CaMn}_{0.98} \mathrm{Nb}_{0.02} \mathrm{O}_{3}$ & -255 & 31 & & & 0.32 & 1050 \\
\hline [108] & $\mathrm{SrMn}_{0.7} \mathrm{Ru}_{0.3} \mathrm{O}_{3}$ & -40 & 50 & 1.8 & & 0.01 & 370 \\
\hline [109] & $\mathrm{Ca}_{0.9} \mathrm{Nd}_{0.1} \mathrm{MnO}_{3}$ & -150 & 160 & & 398 & & 1123 \\
\hline [110] & $\operatorname{Sr}\left(\mathrm{Mn}_{0.975} \mathrm{Mo}_{0.025}\right) \mathrm{O}_{3}$ & -120 & 0.13 & 5 & & 0.003 & 400 \\
\hline [111] & $\mathrm{Ca}_{0.8} \mathrm{Nd}_{0.2} \mathrm{MnO}_{3}$ & -62 & 280 & 1.3 & & 0.17 & 873 \\
\hline [112] & $\mathrm{Sr}_{0.9} \mathrm{Ti}_{0.1} \mathrm{MnO}_{3}$ & -340 & 2.25 & & 25 & & 800 \\
\hline [113] & $\left(\operatorname{Pr}_{0.9} \mathrm{Ca}_{0.1}\right) \mathrm{CoO}_{3}$ & 106 & 220 & 1.9 & & 0.047 & 358 \\
\hline$[114]$ & $\begin{array}{c}\mathrm{Pr}_{0.9} \mathrm{Ca}_{0.1} \mathrm{CoO}_{3} \\
{\left[\mathrm{RCoO}_{3}(\mathrm{R}=\mathrm{Pr}, \mathrm{Nd}, \mathrm{Sm}, \mathrm{Gd}, \mathrm{Dy}, \mathrm{Ho})\right]}\end{array}$ & 125 & 220 & 1.6 & & 0.046 & 450 \\
\hline [115] & $\begin{array}{l}\mathrm{TbCoO}_{3} \\
\mathrm{DyCoO}_{3}\end{array}$ & 80 & 200 & 1.6 & & 0.05 & 873 \\
\hline [116] & $\mathrm{Nd}_{0.95} \mathrm{Sr}_{0.05} \mathrm{CoO}_{3}$ & 130 & & & & & 400 \\
\hline
\end{tabular}


Table 1. Cont.

\begin{tabular}{|c|c|c|c|c|c|c|c|}
\hline Ref. & Materials & $\begin{array}{c}\text { Seebeck } \\
\left(\mu \mathrm{V} \cdot \mathrm{K}^{-1}\right)\end{array}$ & $\begin{array}{l}\text { Electrical Conductivity } \\
\left(\mathrm{S} \cdot \mathrm{cm}^{-1}\right)\end{array}$ & $\begin{array}{l}\text { Thermal Conductivity } \\
\left(\mathrm{W} \cdot \mathrm{m}^{-1} \cdot \mathrm{K}^{-1}\right)\end{array}$ & $\begin{array}{c}\text { Power Factor } \\
\left(\mu \mathrm{W} \cdot \mathrm{K}^{-2} \cdot \mathrm{m}^{-1}\right)\end{array}$ & ZT & Measure Temp. (K) \\
\hline \multirow[b]{2}{*}{ [117] } & $\mathrm{Nd}_{0.99} \mathrm{Sr}_{0.01} \mathrm{CoO}_{3}$ & 300 & & & & & 290 \\
\hline & $\mathrm{Pr}_{0.99} \mathrm{Sr}_{0.01} \mathrm{CoO}_{3}$ & 450 & & & & & 270 \\
\hline [118] & $\mathrm{LaCoO}_{3}$ & 1200 & & & & & 100 \\
\hline [119] & $\mathrm{La}_{0.975} \mathrm{Sr}_{0.025} \mathrm{CoO}_{3}$ & 280 & & & & & 300 \\
\hline [120] & $\mathrm{La}_{0.95} \mathrm{Sr}_{0.05} \mathrm{CoO}_{3}$ & 720 & 100 & & & & 280 \\
\hline [121] & $\mathrm{Ho}_{0.9} \mathrm{Ca}_{0.1} \mathrm{CoO}_{3}$ & 220 & 20 & 0.75 & & 0.051 & 573 \\
\hline [122] & $\mathrm{La}_{0.875} \mathrm{Sr}_{0.125} \mathrm{CoO}_{3}$ & 100 & & 6 & & 0.035 & 230 \\
\hline [123] & $\mathrm{La}_{0.95} \mathrm{Sr}_{0.05} \mathrm{CoO}_{3}$ & 720 & 20 & 0.037 & & 0.18 & 300 \\
\hline [124] & $\mathrm{La}_{0.95} \mathrm{Sr}_{0.05} \mathrm{CoO}_{3}$ & 170 & & 1.2 & & 0.033 & 300 \\
\hline [125] & $\mathrm{La}_{0.9} \mathrm{Sr}_{0.1} \mathrm{CoO}_{3}$ & 120 & & 1.5 & & 0.046 & 300 \\
\hline [126] & $\mathrm{La}_{0.9} \mathrm{~Pb}_{0.1} \mathrm{CoO}_{3}$ & 110 & 333 & 0.8 & & 0.23 & 575 \\
\hline \multirow[t]{2}{*}{ [127] } & $\mathrm{Nd}_{0.995} \mathrm{Ca}_{0.005} \mathrm{CoO}_{3}$ & 500 & 1.1 & & & & 300 \\
\hline & $\mathrm{LaCo}_{0.99} \mathrm{Mn}_{0.01} \mathrm{O}_{3}$ & -200 & & & & & 300 \\
\hline [128] & $\mathrm{La}_{0.97} \mathrm{Ba}_{0.03} \mathrm{CoO}_{3}$ & 80 & 40 & & 80 & 0.08 & 420 \\
\hline \multirow[t]{3}{*}{ [129] } & $\mathrm{YCo}_{0.98} \mathrm{Ni}_{0.02} \mathrm{O}_{3}$ & 900 & & & & & 300 \\
\hline & $\mathrm{LaCoO}_{3}$ & 600 & 0.067 & & & & 300 \\
\hline & $\mathrm{La}_{0.98} \mathrm{Sr}_{0.02} \mathrm{CoO}_{3}$ & 350 & 0.3 & & & & 300 \\
\hline \multirow[t]{3}{*}{ [130] } & $\mathrm{La}_{0.99} \mathrm{Ce}_{0.01} \mathrm{CoO}_{3}$ & -300 & 0.03 & & & & 300 \\
\hline & $\mathrm{LaCo}_{0.995} \mathrm{Ga}_{0.005} \mathrm{O}_{3}$ & 480 & & & & & 300 \\
\hline & $\mathrm{LaCo}_{0.995} \mathrm{Ti}_{0.005} \mathrm{O}_{3}$ & -200 & & & & & 300 \\
\hline [131] & $\mathrm{LaCo}_{0.92} \mathrm{Ni}_{0.08} \mathrm{O}_{2.9}$ & 220 & 33.3 & 0.35 & & 0.2 & 300 \\
\hline [132] & $\mathrm{La}_{0.94} \mathrm{Sr}_{0.06} \mathrm{CoO}_{3}$ & 180 & & 2 & & 0.048 & 300 \\
\hline [133] & $\mathrm{La}_{0.9} \mathrm{Sr}_{0.1} \mathrm{CoO}_{3}$ & & & & & 0.046 & 300 \\
\hline [134] & $\mathrm{La}_{0.9} \mathrm{Sr}_{0.1} \mathrm{FeO}_{3}$ & 380 & & & & & 1173 \\
\hline [135] & $\mathrm{Pr}_{0.9} \mathrm{Sr}_{0.1} \mathrm{FeO}_{3}$ & 140 & & 0.8 & & 0.024 & 850 \\
\hline \multirow[t]{2}{*}{ [136] } & $\mathrm{La}_{0.95} \mathrm{Sr}_{0.05} \mathrm{FeO}_{3}$ & 230 & & 1.8 & & 0.076 & 1273 \\
\hline & $\mathrm{Ca}_{2} \mathrm{FeMoO}_{6}$ & -108 & 300 & 3.2 & & 0.14 & 1250 \\
\hline \multirow[t]{2}{*}{ [137] } & $\mathrm{Ca}_{1.9} \mathrm{Sr}_{0.1} \mathrm{FeMoO}_{6}$ & -110 & 250 & 3.0 & & 0.14 & 1250 \\
\hline & $\mathrm{Ca}_{1.8} \mathrm{Sr}_{0.2} \mathrm{FeMoO}_{6}$ & -100 & 260 & 2.8 & & 0.14 & 1250 \\
\hline [138] & $\mathrm{Sr}_{1.6} \mathrm{~K}_{0.4} \mathrm{FeMoO}_{6}$ & -48 & & 3.1 & 450 & 0.24 & 1250 \\
\hline [139] & $\mathrm{Ba}_{2} \mathrm{FeMoO}_{6}$ & -1350 & & & & 0.995 & 300 \\
\hline [140] & $\mathrm{LaNi} 0.8 \mathrm{Cu} 0.2 \mathrm{O}_{3}$ & -26 & 600 & & 40 & & 600 \\
\hline [141] & $\mathrm{BaSn}_{0.99} \mathrm{Co}_{0.01} \mathrm{O}_{3}$ & 1000 & & & & & 700 \\
\hline [142] & $\mathrm{Sr}_{0.98} \mathrm{La}_{0.02} \mathrm{SnO}_{3}$ & -80 & 0.03 & & & & 300 \\
\hline [143] & $\mathrm{Ba}_{0.998} \mathrm{La}_{0.002} \mathrm{SnO}_{3}$ & -170 & 150 & 4 & & 0.1 & 1073 \\
\hline [144] & $\mathrm{Sr}_{0.99} \mathrm{La}_{0.01} \mathrm{SnO}_{3}$ & -80 & 1.5 & 3.6 & 120 & 0.05 & 1073 \\
\hline [145] & $\mathrm{BaSnO}_{3}$ & -130 & 300 & 3.4 & 1400 & 0.65 & 1200 \\
\hline [146] & $\mathrm{Ba}_{0.4} \mathrm{Sr}_{0.6} \mathrm{PbO}_{3}$ & 125 & 250 & 2 & & 0.13 & 673 \\
\hline [147] & $\mathrm{Ba}_{0.2} \mathrm{Sr}_{0.8} \mathrm{PbO}_{3}$ & -190 & 79 & 1.8 & & 0.13 & 680 \\
\hline
\end{tabular}


Table 1. Cont.

\begin{tabular}{|c|c|c|c|c|c|c|c|}
\hline Ref. & Materials & $\begin{array}{c}\text { Seebeck } \\
\left(\mu \mathrm{V} \cdot \mathrm{K}^{-1}\right)\end{array}$ & $\begin{array}{l}\text { Electrical Conductivity } \\
\left(\mathrm{S} \cdot \mathrm{cm}^{-1}\right)\end{array}$ & $\begin{array}{l}\text { Thermal Conductivity } \\
\left(\mathrm{W} \cdot \mathrm{m}^{-1} \cdot \mathrm{K}^{-1}\right)\end{array}$ & $\begin{array}{c}\text { Power Factor } \\
\left(\mu \mathrm{W} \cdot \mathrm{K}^{-2} \cdot \mathrm{m}^{-1}\right)\end{array}$ & ZT & Measure Temp. (K) \\
\hline [148] & $\mathrm{Sr}_{0.7} \mathrm{Ba}_{0.3} \mathrm{~Pb}_{0.99} \mathrm{Bi}_{0.01} \mathrm{O}_{3}$ & -70 & & & 390 & & 900 \\
\hline [149] & $\mathrm{Ba}_{0.77} \mathrm{~K}_{0.23} \mathrm{BiO}_{3}$ & 3.2 & 10 & & & & 290 \\
\hline [150] & $\mathrm{BaBi}_{0.9} \mathrm{Sb}_{0.1} \mathrm{O}_{3}$ & 260 & & & 10 & & 850 \\
\hline [151] & $\mathrm{BaMoO}_{3}$ & -30 & & & & 0.015 & 1000 \\
\hline [152] & $\mathrm{Sr}_{1.4} \mathrm{Ba}_{0.6} \mathrm{Fe}_{0.8} \mathrm{Mo}_{0.8} \mathrm{Mn}_{0.2} \mathrm{~V}_{0.2} \mathrm{O}_{6}$ & -58 & 316 & & 83.2 & & 973 \\
\hline [153] & $\mathrm{SrRuO}_{3}$ & 36 & & 5.3 & & 0.03 & 1200 \\
\hline \multirow{2}{*}{ [154] } & $\mathrm{Sr}_{2} \mathrm{RuYO}_{6}$ & -250 & & & & & 1200 \\
\hline & $\mathrm{Sr}_{2} \mathrm{RuErO}_{6}$ & -250 & & & & & 1200 \\
\hline [155] & $\left(\mathrm{Sr}_{0.95} \mathrm{La}_{0.05}\right)_{2} \mathrm{RuErO}_{6}$ & -160 & & & & 0.001 & 800 \\
\hline \multirow[t]{2}{*}{ [156] } & $\mathrm{AgNbO}_{3}$ & $\begin{array}{c}700 \\
-500\end{array}$ & & & & & 800 \\
\hline & $\mathrm{AgTaO}_{3}$ & 710 & & & & & 800 \\
\hline [157] & $\mathrm{K}_{0.991} \mathrm{Ba}_{0.009} \mathrm{TaO}_{3}$ & 200 & 333 & & & 0.03 & 300 \\
\hline [88] & $\mathrm{KTaO}_{3}$ & -280 & & & & & 1000 \\
\hline [158] & $\mathrm{BaUO}_{3}$ & -170 & 0.1 & 0.8 & & 0.0002 & 880 \\
\hline [159] & $\mathrm{BaCe}_{0.95} \mathrm{Y}_{0.05} \mathrm{O}_{3}$ & -220 & & & & & 873 \\
\hline [35] & $\mathrm{C}_{6} \mathrm{H}_{4} \mathrm{NH}_{2} \mathrm{CuBr}_{2} \mathrm{I}$ & -82 & 2950 & 3.25 & & 0.21 & 363 \\
\hline \multirow[t]{6}{*}{ [33] } & $\mathrm{CH}_{3} \mathrm{NH}_{3} \mathrm{PbI}_{3}$-n-type & -238 & 160 & 0.1 & 8.4 & 0.61 & 300 \\
\hline & p-type & 181 & 94 & 0.06 & 3.1 & 0.25 & 300 \\
\hline & n-type & -362 & 89 & 0.145 & 10.5 & 1.61 & 600 \\
\hline & p-type & 295 & 41 & 0.06 & 3.6 & 0.71 & 600 \\
\hline & n-type & -428 & 68 & 0.151 & 11.3 & 2.56 & 800 \\
\hline & p-type & 358 & 25 & 0.04 & 3.3 & 1.08 & 800 \\
\hline \multirow[t]{3}{*}{ [160] } & $\mathrm{CH}_{3} \mathrm{NH}_{3} \mathrm{SnI}_{3}$ & 720 & 0.001 & 0.08 & & 0.01 & 295 \\
\hline & $\mathrm{CH}_{3} \mathrm{NH}_{3} \mathrm{PbI}_{3}$ & 700 & $10^{-7}$ & 0.5 & & $10^{-7}$ & 295 \\
\hline & (MA)PbI $\mathrm{PbI}_{3}$ & 200 & & & & 0.44 & 298 \\
\hline \multirow{3}{*}{ [34] } & (MA)SnI ${ }_{3}$ & 200 & & & & 0.44 & 298 \\
\hline & (FA) $\mathrm{PbI}_{3}$ & 100 & & & & 0.43 & 298 \\
\hline & (FA) $\mathrm{SnI}_{3}$ & 150 & & & & 0.35 & 298 \\
\hline \multirow[t]{2}{*}{ [161] } & $\mathrm{CH}_{3} \mathrm{NH}_{3} \mathrm{PbI}_{3}$-n-type & 80 & 1.2 & & & 0.9 & 330 \\
\hline & $\mathrm{CH}_{3} \mathrm{NH}_{3} \mathrm{PbI}_{3}$-p-type & 50 & 1 & & & 1.25 & 330 \\
\hline \multirow{2}{*}{ [162] } & $\mathrm{CsSnI}_{3}$ & & & 0.18 & & 0.63 & 1000 \\
\hline & $\mathrm{CsPbI}_{3}$ & & & 0.1 & & 0.64 & 1000 \\
\hline
\end{tabular}




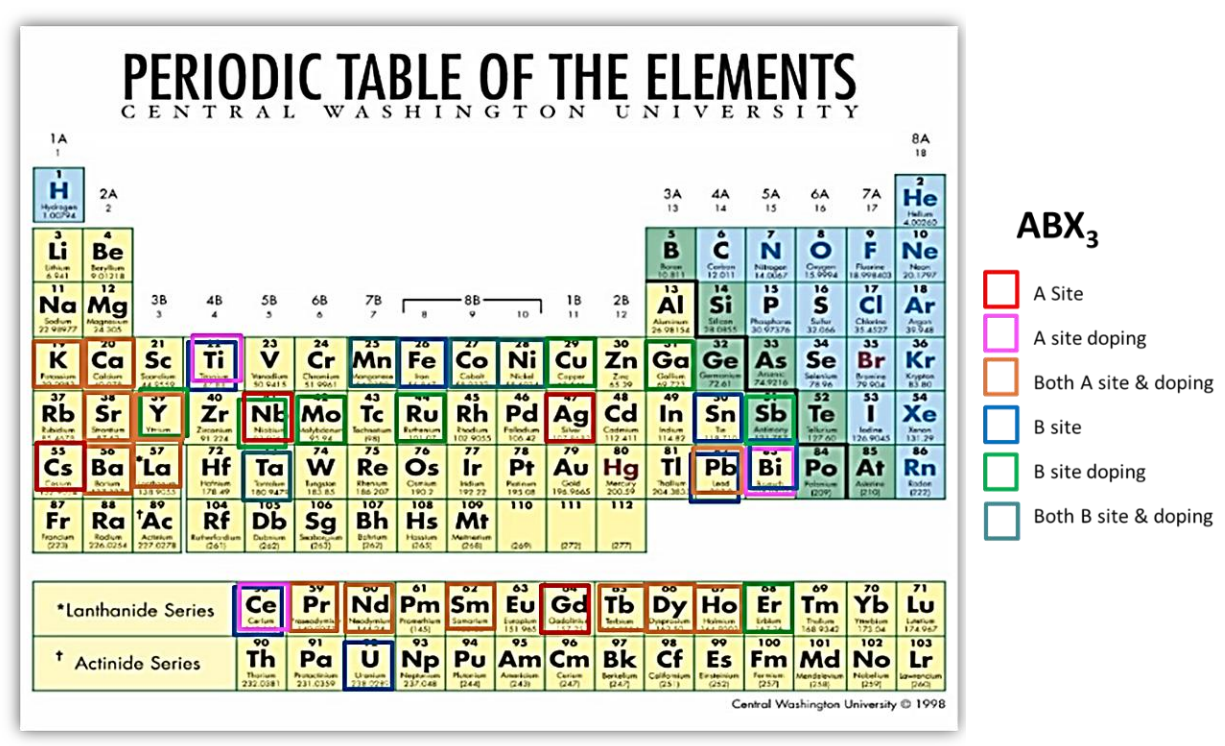

Figure 4. Elements that were used for perovskites in the A and B sites, which have been applied for thermoelectrics.

\section{Oxide Perovskites}

Oxide perovskite materials have been used for the application of thermoelectrics. Usually, oxide perovskite materials have relatively high Seebeck coefficient, low electrical conductivity, and high thermal conductivity at a specific temperature. For example, polycrystalline $\mathrm{SrTiO}_{3}$ has an $\mathrm{S}$ of $-410 \mu \mathrm{V} \cdot \mathrm{K}^{-1}$, a $\sigma$ of $0.18 \mathrm{~S} \cdot \mathrm{cm}^{-1}$ and a $\mathrm{K}$ of $7.5 \mathrm{~W} \cdot \mathrm{m}^{-1} \cdot \mathrm{K}^{-1}$ at $375 \mathrm{~K}$ [59]. In general, two different approaches have been utilized to enhance ZT of thermoelectric materials. One approach is tuning the carrier concentration (n) to a suitable range since three interdependent thermoelectric parameters (i.e., $S, \sigma$, and $\mathrm{k}$ ) are functional to the carrier concentration [10]. The other approach is engineering of the material properties and structure of thermoelectric materials to decouple the parameters [16,163-165]. A variety of elements have been used for oxide perovskite materials, shown in Figure 4 . In this review, the oxide perovskite materials were classified based on B-site elements, and their TE properties were discussed.

\subsection{Titanium (Ti) as B-Site $\left(\mathrm{ATiO}_{3}\right)$}

The reported ZT as a function of temperature, when Ti was used as B-site, was presented in Figure 5. All the materials are n-type thermoelectric materials.

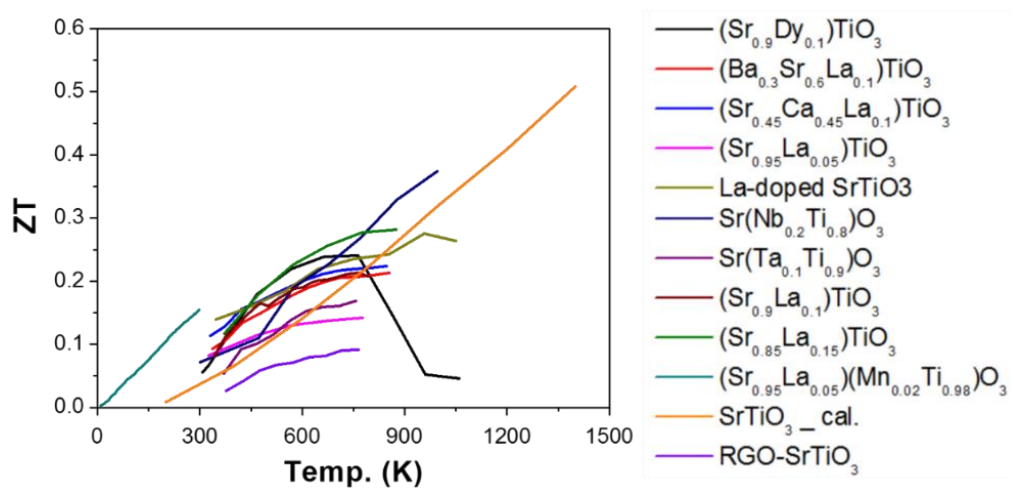

Figure 5. $\mathrm{ZT}$ value of $\mathrm{ATiO}_{3}$ based oxide perovskite materials, all the materials are n-type semiconductors. The symbol "cal." means the results come from the calculation. 


\subsubsection{Enhancing Electrical Conductivity}

To enhance the electrical conductivity of $\mathrm{ATiO}_{3}$, chemical doping is applied. Although the electrical conductivity, Seebeck coefficient, and thermal conductivity are interdependent, it is necessary to tune the carrier concentration to its optimum range. The electrical conductivity was modified by oxygen vacancy $[38,57-59]$, and chemical substitution in A-site [40,60-67] and B-site $[65,68]$.

Oxygen vacancy has been induced to enhance the electrical conductivity. The perovskite-type $\mathrm{ATiO}_{3}$ is a wide gap band-insulator, where the valence band comes from the oxygen $2 p$ state and the conduction band from the Ti 3d-t2g state with threefold orbital degeneracy [58], Figure 6 shows the band structure and the density of states of $\mathrm{SrTiO}_{3}$ (STO) [80]. The oxygen vacancy, which can be introduced into perovskite materials by controlling oxygen partial pressure, hydrogen reduction, and reduced graphene oxide, can generally add two electrons in the Ti site, providing charge carriers, therefore enhancing the electrical conductivity [38,57-59]. For example, Onoda et al. investigated the perovskite-type oxygen deficient system $\mathrm{SrTiO}_{3-\delta / 2}$ with $0.0046 \leq \delta<0.06$, the carrier concentration was enhanced from $2.5 \times 10^{18}$ to $1.0 \times 10^{21} \mathrm{~cm}^{-3}$, when $\delta$ increased from 0.0046 to 0.06 , resulting in the enhancement of electrical conductivity from about 5 to $1000 \mathrm{~S} \cdot \mathrm{cm}^{-1}$. The power factor $2000 \mu \mathrm{W} \cdot \mathrm{m}^{-1} \cdot \mathrm{K}^{-2}$ was obtained with the carrier concentration of $2 \times 10^{20} \mathrm{~cm}^{-3}$ [58]. Choi et al. investigated La-doped $\mathrm{SrTiO}_{3}$ thin films with controlled elemental vacancies by varying the oxygen partial pressure $\mathrm{P}\left(\mathrm{O}_{2}\right)$ during the film growth [38]. Decreasing $\mathrm{P}\left(\mathrm{O}_{2}\right)$ would increase the cation (La and $\mathrm{Sr}$ ) and oxygen vacancies [38]. The cation vacancies are known to compensate the generation of carriers by the oxygen vacancies [38]. Also, it also expands the lattice, thereby disturbing the carrier transport. The carrier concentration was tuned from $\sim 0.43 \times 10^{21}$ to $1.15 \times 10^{21} \mathrm{~cm}^{-3}$ when oxygen partial pressure decreased from $10^{-2}$ to $10^{-6}$ Torr [38]. Seebeck coefficient of the La-doped $\mathrm{SrTiO}_{3}$ thin films can be modulated from -120 to $-260 \mu \mathrm{V} \cdot \mathrm{K}^{-1}$ [38]. Ravichandran et al. reported that the oxygen vacancy can tune the carrier concentration from $1 \times 10^{21}$ to $3 \times 10^{21} \mathrm{~cm}^{-3}$ at La doping level of $15 \%$ in La-doped $\mathrm{SrTiO}_{3}$, and a $\mathrm{ZT}$ value of 0.28 was achieved at $873 \mathrm{~K}$ at a carrier concentration of $2.5 \times 10^{21} \mathrm{~cm}^{-3}$ [57]. Feng et al. induced the oxygen vacancy into undoped $\mathrm{SrTiO}_{3}$ (STO) by hydrogen reduction (STO-H) and reduced graphene oxide (RGO). Their results showed that only $0.64 \mathrm{vol} \%$ of graphene content would enhance electrical properties of STO significantly, where the carrier concentration was $3.64 \times 10^{18}, 4.54 \times 10^{19}$, and $1.59 \times 10^{20} \mathrm{~cm}^{-3}$ for pure STO, STO-H, and $\mathrm{RGO} / \mathrm{STO}$, respectively. Additionally, the electrical conductivity increased from 2 to 14 to $30 \mathrm{~S} \cdot \mathrm{cm}^{-1}$ at $760 \mathrm{~K}$, when the sample changed from pure STO to STO-H to RGO/STO. Electron energy loss spectrum confirmed high oxygen vacancy concentration in the RGO rich area in RGO/STO composite. The ZT value was increased to 0.09 at $760 \mathrm{~K}$ for RGO/STO composite, compared to 0.008 for pure STO [59]. Additionally, Lee et al. reported that electrical conductivity of $\mathrm{BaTiO}_{3}$ can reach $11 \mathrm{~S} \cdot \mathrm{cm}^{-1}$ at $300 \mathrm{~K}$ with a carrier concentration of $\sim 3 \times 10^{20}$ by inducing oxygen vacancy [79], while the single crystal $\mathrm{BaTiO}_{3}$ shows electrical conductivity of $0.05 \mathrm{~S} \cdot \mathrm{cm}^{-1}$ at $300 \mathrm{~K}$ [70]. However, the Seebeck coefficient decreased to $-280 \mu \mathrm{V} \cdot \mathrm{K}^{-1}$ [79], compared to $-550 \mu \mathrm{V} \cdot \mathrm{K}^{-1}$ at $300 \mathrm{~K}$ for single crystal $\mathrm{BaTiO}_{3}$ [70]. In short, the oxygen vacancy can increase the carrier concentration of the $\mathrm{ATiO}_{3}$, thus improving the electrical conductivity. Additionally, oxygen vacancy can also reduce the lattice thermal conductivity because of phonon scattering [79]. However, the strategy of introducing oxygen vacancy needs to cooperate with other types of doping or strategies to achieve relatively high ZT value.

Additionally, chemical substitution (such as La [60-67,74], Ce [66], Ba [39,72], Pr [40], and Y [71]) in A-site is a widely-used method to enhance the electrical conductivity of $\mathrm{ATiO}_{3}$. La is the most widely studied A-site doping element in $\mathrm{SrTiO}_{3}$. The carrier concentration of $\mathrm{Sr}_{1-x} \mathrm{La}_{x} \mathrm{TiO}_{3}$ increases from $2.0 \times 10^{18}$ to $9.0 \times 10^{21}$, when $x$ increased from 0 to 0.5 . As a result, the electrical conductivity is enhanced from 0.3 to $2000 \mathrm{~S} \cdot \mathrm{cm}^{-1}$ [60-66,74]. Since the electrical conductivity is interrelated with Seebeck coefficient, heavily La-doped STO also has a relatively low Seebeck coefficient. Additionally, La doping does not necessarily increase the thermal conductivity, which is probably attributed to the decrease of the mean free path of the phonons caused by lattice defects [63]. As a result, the ZT value achieved for $\mathrm{Sr}_{0.95} \mathrm{La}_{0.05} \mathrm{TiO}_{3}$ (La-doped STO) was 0.14 at $773 \mathrm{~K}$ with $\mathrm{n}$ of about $8 \times 10^{20} \mathrm{~cm}^{-3}$ 
and $\sigma$ of $150 \mathrm{~S} \cdot \mathrm{cm}^{-1}$ [63]. Theoretical calculation by Boltzmann transport theory predicted that a ZT value of 0.7 at $1400 \mathrm{~K}$ could be achieved with an $\mathrm{n}$ of $4 \times 10^{20} \mathrm{~cm}^{-3}$ for La-doped STO [85]. However, such a high ZT value has not been obtained experimentally. Additionally, La was also used to dope STO together with $\mathrm{Ba}$ (i.e., $\mathrm{Sr}_{0.9-\mathrm{x}} \mathrm{Ba}_{\mathrm{x}} \mathrm{La}_{0.1} \mathrm{TiO}_{3}$ ) [72] and oxygen vacancy [57]. The electrical conductivity of $\mathrm{Sr}_{0.9-\mathrm{x}} \mathrm{Ba}_{\mathrm{x}} \mathrm{La}_{0.1} \mathrm{TiO}_{3}$ increased from 200 to $2500 \mathrm{~S} \cdot \mathrm{cm}^{-1}$, when $\mathrm{x}$ increased from 0 to 0.9 at $420 \mathrm{~K}$ [72]. This is caused by the decrease of the Ti-Ti distance, which increases the overlap of Ti $3 \mathrm{~d}$ orbital in the conduction band [72]. The highest ZT value achieved in the study is 0.13 at $420 \mathrm{~K}$, with a formula of $\left(\mathrm{Ba}_{0.3} \mathrm{Sr}_{0.6} \mathrm{La}_{0.1}\right) \mathrm{TiO}_{3}$ [72]. Moreover, when the La content increased from 0 to 0.15, the carrier concentration of oxygen vacancy doped STO increased from $\sim 3 \times 10^{20}$ to $3 \times 10^{21} \mathrm{~cm}^{-3}$, and electrical conductivity from $\sim 70$ to $700 \mathrm{~S} \cdot \mathrm{cm}^{-1}$ [57]. The highest ZT value of 0.28 was achieved at $873 \mathrm{~K}$ at a carrier concentration of $2.5 \times 10^{21} \mathrm{~cm}^{-3}$ [57]. Furthermore, Pr was also used as A-site dopant in $\mathrm{Sr}_{1-\mathrm{x}} \mathrm{Pr}_{\mathrm{x}} \mathrm{TiO}_{3}(0<\mathrm{x}<0.125)$, in which, a linear increase in carrier concentration is observed with increasing Pr concentration [40]. The carrier concentration increased from $0.3 \times 10^{21} \mathrm{~cm}^{-3}$ to $2.1 \times 10^{21}$, when $x$ changed from 0 to 0.125 [40], and the electrical conductivity was enhanced from 250 to $700 \mathrm{~S} \cdot \mathrm{cm}^{-1}$, when $x$ changed from 0.05 to 0.125 [40]. The mobility of STO was enhanced to about $12 \mathrm{~cm}^{2} \cdot \mathrm{V}^{-1} \cdot \mathrm{s}^{-1}$ [40], compared to $4-8 \mathrm{~cm}^{2} \cdot \mathrm{V}^{-1} \cdot \mathrm{s}^{-1}$ [166-169], in which the dramatic enhancement in carrier mobility was attributed to the formation of Pr-rich grain boundaries [40]. A ZT value of 0.4 at $773 \mathrm{~K}$ was achieved attributed to the high mobility [40]. In short, the combination of chemical doping and oxygen vacancy can lead to relatively high ZT value [57]. Furthermore, Pr doping with Pr-rich boundary can achieve high carrier concentration and mobility, which resulted in the highest ZT value obtained experimentally so far for $\mathrm{ATiO}_{3}[40]$.

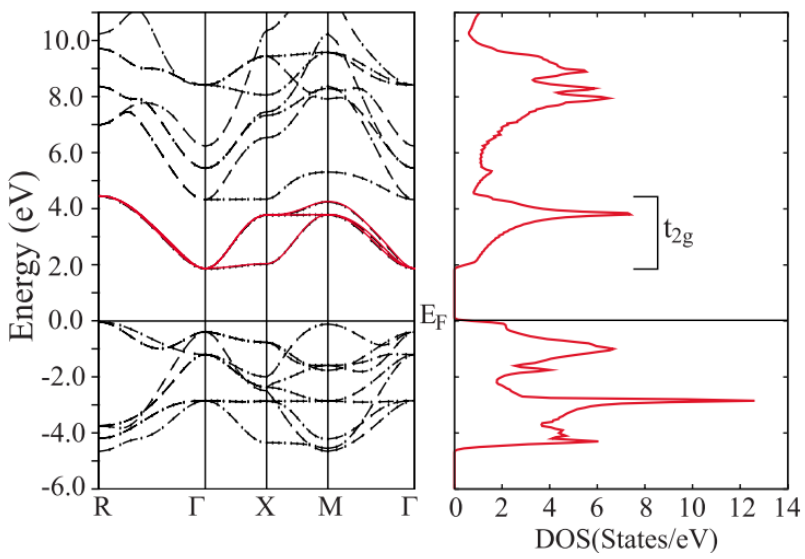

Figure 6. The band structure and the density of states of $\mathrm{SrTiO}_{3}$ [80]. Copyright 2010, Physical Review B.

Furthermore, chemical doping in B-site was applied to enhance the electrical conductivity. $\mathrm{Nb}[65,68,69,76], \mathrm{Ta}$ [78], $\mathrm{Mn}$ [83] and $\mathrm{Co}$ [89] was used as B-site dopant in $\mathrm{SrTiO}_{3}$. $\mathrm{Nb}$ is the most widely used B-site dopant $\left(\mathrm{Sr}\left(\mathrm{Nb}_{\mathrm{x}} \mathrm{Ti}_{1-\mathrm{x}}\right) \mathrm{O}_{3}, 0.01<\mathrm{x}<0.4\right)$, in which substituted $\mathrm{Nb}^{5+}$ at $\mathrm{Ti}^{4+}$ site generates carrier electrons [68]. In the doping range, the carrier concentration was tuned from $\sim 0.1 \times 10^{21}$ to $7 \times 10^{21} \mathrm{~cm}^{-3}$, leading to electrical conductivity varying from $\sim 95$ to $353 \mathrm{~S} \cdot \mathrm{cm}^{-1}[65,68,69,76]$. Also, the $\mathrm{Nb}$-doped $\mathrm{SrTiO}_{3}$ film has a large Seebeck coefficient. For example, a rather large IS | (i.e., $160 \mu \mathrm{V} \cdot \mathrm{K}^{-1}$ ) is observed for the $40 \% \mathrm{Nb}$-doped $\mathrm{SrTiO}_{3}$ film in spite of an extremely high carrier concentration (i.e., $7 \times 10^{21} \mathrm{~cm}^{-3}$ ) [68]. It is worth mention that $|\mathrm{S}|$ of n-type lead telluride $(\mathrm{PbTe})$ is less than $50 \mu \mathrm{V} \cdot \mathrm{K}^{-1}$ in the carrier concentration range of $10^{20} \mathrm{~cm}^{-3}[16,170]$. The large $|\mathrm{S}|$ values in high carrier concentration films result from the gradual increase in effective mass $\left(\mathrm{m}^{*} / \mathrm{m}^{0}\right.$, from 7 to 11) $[65,68]$. The enhancement of $\mathrm{m}^{*} / \mathrm{m}^{0}$ is owing to an increase in the lattice parameter or the distance between two neighboring Ti ions, leading to the decrease in overlapping between Ti $3 \mathrm{~d}-\mathrm{t} 2 \mathrm{~g}$ orbitals $[65,68]$. Moreover, $\mathrm{Nb}$ substitute can also suppress the thermal conductivity of STO [77]. A ZT value of $\sim 0.35-0.37$ at $1000 \mathrm{~K}$ was achieved for $20 \% \mathrm{Nb}$-doped STO [68,76]. Additionally, the 
theoretical analysis by advanced ab initio calculations showed that superlattice in $\mathrm{Nb}$-doped STO could remarkably improve the Seebeck coefficient compared to the bulk at equivalent doping concentration, and the Seebeck coefficient in similar heterostructures would be improved more by weak, rather than tight, spatial confinement [82]. Moreover, the slight Mn substitution in B-site of $\mathrm{Sr}_{1-x} \mathrm{LaxTiO}_{3}$ can also enhance the effective mass of electrons, giving rise to an increase in IS I [83]. For example, the $\mathrm{S}$ was enhanced from -120 to $-180 \mu \mathrm{V} \cdot \mathrm{K}^{-1}$, and the $\mathrm{ZT}$ value was changed from 0.07 to 0.15 at $300 \mathrm{~K}$ when the composition is tuned from $\mathrm{Sr}_{0.95} \mathrm{La}_{0.05} \mathrm{TiO}_{3}$ to $\mathrm{Sr}_{0.95} \mathrm{La}_{0.05} \mathrm{Ti}_{0.96} \mathrm{Mn}_{0.04} \mathrm{O}_{3}$ [83]. This phenomenon can be attributed to the coupling between itinerant electrons and localized spins or coupling between itinerant electrons and local lattice distortion around $\mathrm{Mn}^{3+}$ ions [83]. Additionally, as Ta and Co-doped STO, the ZT value was 0.17 at $752 \mathrm{~K}$ and 0.135 at $300 \mathrm{~K}$ for $\operatorname{SrTi}_{0.9} \mathrm{Ta}_{0.1} \mathrm{O}_{3}$ [78] and $\mathrm{SrTi}_{0.875} \mathrm{Co}_{0.125} \mathrm{O}_{3}$ [89], respectively.

In short, the B-site doping cannot tune the carrier concentration as efficiently as A-site doping, but it can increase the effective mass of the materials, therefore enhancing the Seebeck coefficient at high carrier concentrations. In perspective, it can be promising to introduce both A-site and B-site doping into the materials, where A-site improves the electrical properties and B-site enhances the Seebeck coefficient.

\subsubsection{Decoupling Electrical Conductivity and Seebeck Coefficient}

The Seebeck coefficient is negatively interrelated with electrical conductivity (Equations (3) and (4)), where Seebeck coefficient decreases with increasing carrier concentration. However, there are some strategies that can enhance the Seebeck coefficient without reducing electrical conductivity. For example, the existence of oxygen vacancy can change the density of electronic states around the Fermi energy, which results in larger Seebeck coefficient [62-64]. The Seebeck coefficient of oxygen-deficient samples (e.g., $\mathrm{S}$ of $-300 \mu \mathrm{V} \cdot \mathrm{K}^{-1}$ at $750 \mathrm{~K}$ for $\mathrm{Sr}_{0.9} \mathrm{La}_{0.1} \mathrm{TiO}_{3-\delta}$ ) are larger than those with near-stoichiometric ones with the same La doping level (e.g., $\mathrm{S}$ of $-255 \mu \mathrm{V} \cdot \mathrm{K}^{-1}$ at $750 \mathrm{~K}$ for $\mathrm{Sr}_{0.9} \mathrm{La}_{0.1} \mathrm{TiO}_{3}$ ) [62,63]. This superiority leads to higher $\mathrm{ZT}$ value of 0.21 at $750 \mathrm{~K}$ [64]. Moreover, B-site substitution of Ti by $\mathrm{Nb}[65,68,76]$ and $\mathrm{Mn}[83]$ can also enhance the Seebeck coefficient by increasing the effective mass of electrons. A IS I of $160 \mu \mathrm{V} \cdot \mathrm{K}^{-1}$ is obtained from the $40 \% \mathrm{Nb}$-doped $\mathrm{SrTiO}_{3}$ film despite a high carrier concentration of $7 \times 10^{21} \mathrm{~cm}^{-3}[65,68,76]$. A-site substitution of $\mathrm{Sr}$ by La in $\mathrm{SrTiO}_{3}$ (i.e., $\mathrm{Sr}_{1-\mathrm{x}} \mathrm{La}_{\mathrm{x}} \mathrm{TiO}_{3}, 0.02 \leq \mathrm{x} \leq 0.1$ ) was also reported to have relatively large Seebeck coefficient compared to the materials in the same carrier concentration range of $10^{21} \mathrm{~cm}^{-3}$, which is attributed to the orbital degeneracy of the Ti 3d-t2g conduction band, the relatively large electron effective mass, and large energy-dependent scattering rate [61,74]. Additionally, Sun et al. investigated the TE properties of La-doped $\mathrm{SrTiO}_{3}$ and $\mathrm{Ba}$ doped $\mathrm{KTaO}_{3}$ through the first-principles band calculation. Their results showed that the Seebeck coefficients are higher in multiple band systems than those with single-band [80], since the Fermi level tends to stay lower for systems with multiple bands given a fixed number of doped electrons [80]. Furthermore, quantum confinement effect can effectively enhance the Seebeck coefficient of $\mathrm{SrTiO}_{3}$. Ohta et al. reported a high-density two-dimensional electron gas (2DEG) confined within 0.5 to 16 unit cell layer thickness in $\mathrm{SrTiO}_{3}$ (i.e., $\mathrm{SrTiO}_{3} / \mathrm{SrTi}_{0.8} \mathrm{Nb}_{0.2} \mathrm{O}_{3} / \mathrm{SrTiO}_{3}$ quantum-well, where $\mathrm{n}_{\mathrm{e}}=10^{15} \mathrm{~cm}^{-3}$ for $\mathrm{SrTiO}_{3}$ and $\mathrm{n}_{\mathrm{e}}=2.4 \times 10^{21} \mathrm{~cm}^{-3}$ for $\mathrm{SrTi}_{0.8} \mathrm{Nb}_{0.2} \mathrm{O}_{3}$ ) [75]. A dramatic increase in $|\mathrm{S}|$ at room temperature is observed when the thickness of the $\operatorname{SrTi}_{0.8} \mathrm{Nb}_{0.2} \mathrm{O}_{3}$ layer becomes less than $1.56 \mathrm{~nm}$ (i.e., a four-unit cell layer thickness) [75]. For example, the one unit cell layer thickness of the $\mathrm{SrTi}_{0.8} \mathrm{Nb}_{0.2} \mathrm{O}_{3}$ reached a large IS I of $480 \mu \mathrm{V} \cdot \mathrm{K}^{-1}$ at $300 \mathrm{~K}$, approximately five times larger than that of $\mathrm{SrTi}_{0.8} \mathrm{Nb}_{0.2} \mathrm{O}_{3}$ bulks (i.e., $108 \mu \mathrm{V} \cdot \mathrm{K}^{-1}$ at $300 \mathrm{~K}$ with $\mathrm{n}_{\mathrm{e}}$ of $2.4 \times 10^{21} \mathrm{~cm}^{-3}$ ) [75]. This significant improvement of ISI suggests that strong electron confinement can be achieved by using strongly directive $\mathrm{Ti} 3 \mathrm{~d}(\mathrm{t} 2 \mathrm{~g})$ orbitals; direct overlap between neighboring $3 \mathrm{~d}$ orbitals is relatively small, and carrier electrons tend to localize in the Ti atoms [75]. They also claimed that with the measured ISI of $850 \mu \mathrm{V} \cdot \mathrm{K}^{-1}$, estimated $\sigma_{2 \text { DEG }}$ of $1.4 \times 10^{3} \mathrm{~S} \cdot \mathrm{cm}^{-1}$, and $\mathrm{k}$ of $12 \mathrm{~W} \cdot \mathrm{m}^{-1} \cdot \mathrm{K}^{-1}$ from bulk single-crystal $\mathrm{SrTiO}_{3}$, an estimated $\mathrm{ZT}$ of 2.4 was observed, corresponding to $\mathrm{ZT} \sim 0.24$ for a complete device having the $2 \mathrm{DEG}$ as the active region [75]. 


\subsubsection{Reducing Thermal Conductivity}

The thermal conductivity is correlated with electrical conductivity because of electron contributions (Equation (5)). To decouple to $\mathrm{k}$ and $\sigma$, suppressing the phonon contribution (lattice thermal conductivity, $\mathrm{k}_{1}$ ) is usually applied, which was realized in $\mathrm{ATiO}_{3}$ by grain boundary phonon scattering [59], point defect phonon scattering [73], distortion of crystal lattice [62,77,83], and so on.

For instance, the lattice thermal conductivity of $\mathrm{RGO} / \mathrm{STO}$ is $3.7 \mathrm{~W} \cdot \mathrm{m}^{-1} \cdot \mathrm{K}^{-1}$ at $760 \mathrm{~K}$, which is $37 \%$ lower than that of pure STO (i.e., $5.9 \mathrm{~W} \cdot \mathrm{m}^{-1} \cdot \mathrm{K}^{-1}$ at $760 \mathrm{~K}$ ) [59]. This can be ascribed to the highly restrained grain size in RGO/STO, which is 20 times smaller than that of pure STO [59].

Additionally, $\mathrm{Ca}$ and rare earth elements substitution in A-site can suppress the $\mathrm{k}_{1}$. Ca was used to substituted $\mathrm{Sr}$ in $\mathrm{Sr}_{0.9-\mathrm{x}} \mathrm{Ca}_{\mathrm{x}} \mathrm{La}_{0.1} \mathrm{TiO}_{3}(0<\mathrm{x}<0.6)$, and the resulted showed that the thermal conductivity decreased from 4.7 to $3.3 \mathrm{~W} \cdot \mathrm{m}^{-1} \cdot \mathrm{K}^{-1}$ when $\mathrm{x}$ increased from 0 to 0.6 , which is caused by the point defect scattering and the lowered symmetry [73]. As a result, $\mathrm{Sr}_{0.45} \mathrm{Ca}_{0.45} \mathrm{La}_{0.1} \mathrm{TiO}_{3}$ has a ZT value of 0.22 at $873 \mathrm{~K}$, compared to 0.2 for $\mathrm{Sr}_{0.9} \mathrm{La}_{0.1} \mathrm{TiO}_{3}$ at $873 \mathrm{~K}$ [73]. Muta et al. studied the rare earth (e.g., Y, $\mathrm{La}, \mathrm{Sm}, \mathrm{Gd}$, and $\mathrm{Dy}$ ) doped $\mathrm{SrTiO}_{3}$ [62]. The thermal conductivity of $\mathrm{SrTiO}_{3}$ is dependent on the doping element, namely: the thermal conductivity decrease monotonically with the ionic rare earth radius, in which it decreased from 4.3 to $2.6 \mathrm{~W} \cdot \mathrm{m}^{-1} \cdot \mathrm{K}^{-1}$ when the dopant changed from La to Dy [62]. This phenomenon is caused by lattice distortion with difference ionic radii, leading to phonon scattering [62]. The enhancement of ZT value in this work is owing to reducing the thermal conductivity without deteriorating the electrical conductivity of $\mathrm{SrTiO}_{3}$, and $\left(\mathrm{Sr}_{0.9} \mathrm{Dy}_{0.1}\right) \mathrm{TiO}_{3}$ showed a ZT value of 0.22 at $573 \mathrm{~K}$ [62]. Moreover, Eu ${ }^{2+}$ substitution of $\mathrm{SrTi}_{0.8} \mathrm{Nb}_{0.2} \mathrm{O}_{3}$ can reduce the thermal conductivity without reducing the thermoelectric power factor [77]. The mean free path of the phonon was reduced about $12 \%$ at room temperature when half of the $\mathrm{Sr}^{2+}$ was substituted by $\mathrm{Eu}^{2+}$ [77]. As a result, the $\mathrm{K}$ of the $\mathrm{SrTi}_{0.8} \mathrm{Nb}_{0.2} \mathrm{O}_{3}$ ceramic at room temperature is $8.8 \mathrm{~W} \cdot \mathrm{m}^{-1} \cdot \mathrm{K}^{-1}$, while it decreased to $7.7 \mathrm{~W} \cdot \mathrm{m}^{-1} \cdot \mathrm{K}^{-1}$ with $50 \%$ of the $\mathrm{Sr}$ was substituted by $\mathrm{Eu}$ [77].

Also, the slight $\mathrm{Mn}$ substitution with some defects in B-site of $\mathrm{Sr}_{1-x} \mathrm{LaxTiO}_{3}$ can enhance anharmonic lattice vibrations resulting in inelastic phonon-phonon scattering, which effectively suppresses thermal conductivity at high electrical conductivity [83]. The thermal conductivity was reduced from 7.1 to $3.8 \mathrm{~W} \cdot \mathrm{m}^{-1} \cdot \mathrm{K}^{-1}$, when the composition changed from $\mathrm{Sr}_{0.95} \mathrm{La}_{0.05} \mathrm{TiO}_{3}$ to $\mathrm{Sr}_{0.95} \mathrm{La}_{0.05} \mathrm{Ti}_{0.98} \mathrm{Mn}_{0.02} \mathrm{O}_{3}$ [83]. The $\mathrm{ZT}$ value of $\mathrm{Sr}_{0.95} \mathrm{La}_{0.05} \mathrm{Ti}_{0.98} \mathrm{Mn}_{0.02} \mathrm{O}_{3}$ reached 0.15 at $300 \mathrm{~K}$ compared to 0.07 for $\mathrm{Sr}_{0.95} \mathrm{La}_{0.05} \mathrm{TiO}_{3}$ [83].

In short, among all the strategies (i.e., inducing grain boundary and chemical substitution in A-site and B-site), the most effective strategy to suppress lattice thermal conductivity is by rare earth substitution of A-site [62] and Mn substitution of B-site [83].

\subsection{Manganese ( $\mathrm{Mn})$ as $\mathrm{B}$-Site $\left(\mathrm{AMnO}_{3}\right)$}

The thermoelectric properties of $\mathrm{AMnO}_{3}$ were summarized, and the $\mathrm{ZT}$ values as a function of temperature were shown in Figure 7, where all the materials are n-type semiconductors.

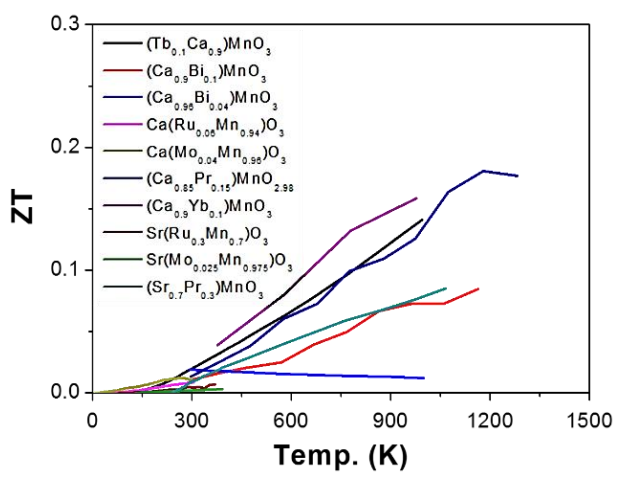

Figure 7. ZT value of $\mathrm{AMnO}_{3}$ based oxide perovskite materials, all the materials are n-type semiconductors. 


\subsubsection{Enhancing Electrical Conductivity}

Chemical doping in A-site was used as a strategy to enhance the electrical conductivity. Multiple elements have been used as A-site dopant in $\mathrm{AMnO}_{3}$, including In [91], $\mathrm{Sn}$ [91], $\mathrm{Sb}$ [91], $\mathrm{Pb}$ [91], Bi [91,103], and rare earth element (e.g., Yb, Y, La, Ce, Sm, Dy, Tb, Ho, and Pr) [90-97]. In general, the electrical conductivity increases as the ionic radius $\left(\mathrm{r}_{\mathrm{A}}\right)$ decreases [95]. The overlapping of $\mathrm{Mn}$ and $\mathrm{O}$ orbitals are substantially influenced by the $\mathrm{r}_{\mathrm{A}}$, which determines the $\mathrm{Mn}-\mathrm{O}-\mathrm{Mn}$ bond angles [95]. The decrease of $r_{A}$ enhances electrical conductivity owing to the strength of the bending of the $\mathrm{Mn}-\mathrm{O}-\mathrm{Mn}$ bond, which narrows the electron conduction bandwidth [95]. Additionally, a relatively high ZT value can be achieved not necessarily at the highest doping level, but sometimes at an optimum doping level. For example, the electrical conductivity of $\mathrm{Ca}_{1-\mathrm{x}} \operatorname{Pr}_{\mathrm{x}} \mathrm{MnO}_{2.98}(0<\mathrm{x}<0.05$, $0.1,0.15$ ) increased from 40 to $125 \mathrm{~S} \cdot \mathrm{cm}^{-1}$ at $1100 \mathrm{~K}$, when $\mathrm{x}$ changed from 0 to 0.15 , leading to a $\mathrm{ZT}$ value of 0.17 at $1100 \mathrm{~K}$ for $\mathrm{Ca}_{0.85} \mathrm{Pr}_{0.15} \mathrm{MnO}_{2.98}$ [94]. The electrical conductivity increased from $\sim 67$ to $333 \mathrm{~S} \cdot \mathrm{cm}^{-1}$ at $1073 \mathrm{~K}$ for $\mathrm{Sr}_{x} \mathrm{Pr}_{1-x} \mathrm{MnO}_{3}$, when $\mathrm{x}$ changed from 0 to 0.7 [97]. The electrical conductivity of $\left(\mathrm{Ca}_{1-\mathrm{x}} \mathrm{R}_{\mathrm{x}}\right) \mathrm{MnO}_{3}(\mathrm{R}: \mathrm{Tb}, \mathrm{Ho}, \mathrm{Y})$ increase with $\mathrm{x}$ value (e.g., from 100 to $182 \mathrm{~S} \cdot \mathrm{cm}^{-1}$ for $\left(\mathrm{Ca}_{1-\mathrm{x}} \mathrm{Tb}_{\mathrm{x}}\right) \mathrm{MnO}_{3}$, from 91 to $250 \mathrm{~S} \cdot \mathrm{cm}^{-1}$ for $\left(\mathrm{Ca}_{1-\mathrm{x}} \mathrm{Ho}_{\mathrm{x}}\right) \mathrm{MnO}_{3}$ when $\mathrm{x}$ increased from 0.1 to 0.3 ), and the highest $\mathrm{ZT}$ value was achieved at $\mathrm{x}=0.1$ for all three materials (e.g., 0.13, 0.08, 0.15, for $\left.\left(\mathrm{Tb}_{0.1} \mathrm{Ca}_{0.9}\right) \mathrm{MnO}_{3},\left(\mathrm{Ho}_{0.1} \mathrm{Ca}_{0.9}\right) \mathrm{MnO}_{3}\right)$, and $\left(\mathrm{Y}_{0.1} \mathrm{Ca}_{0.9}\right) \mathrm{MnO}_{3}$, respectively) [90]. The electrical conductivity of $\mathrm{Ca}_{1-x} \mathrm{Bi}_{x} \mathrm{MnO}_{3}$ increased with $\mathrm{Bi}$ doping from $32 \mathrm{~S} \cdot \mathrm{cm}^{-1}$ at $\mathrm{x}=0.02$ to $222 \mathrm{~S} \cdot \mathrm{cm}^{-1}$ at $\mathrm{x}=0.2$, and a ZT value of 0.086 was achieved when $\mathrm{X}=0.04$ (i.e., $\mathrm{Ca}_{0.96} \mathrm{Bi}_{0.04} \mathrm{MnO}_{3}$ ) at $1000 \mathrm{~K}$ [103]. A ZT value of 0.16 was obtained for $\mathrm{Ca}_{0.9} \mathrm{Yb}_{0.1} \mathrm{MnO}_{3}$ with $\sigma$ of $167 \mathrm{~S} \cdot \mathrm{cm}^{-1}$ at $1000 \mathrm{~K}$ [95].

On the other hand, chemical doping in the B-site was studied to enhance the electrical conductivity. Multiple elements have been used as a B-site dopant in $\mathrm{AMnO}_{3}$, including $\mathrm{Mo}$ [104,110], $\mathrm{Ru}[104,108]$, $\mathrm{Nb}[105,107], \mathrm{Ta}$ [105], and $\mathrm{Ni}[100]$. The electrical conductivity of $\mathrm{CaMn}_{0.96} \mathrm{Mo}_{0.04} \mathrm{O}_{3}$ was measured to be about $154 \mathrm{~S} \cdot \mathrm{cm}^{-1}$, and the ZT value is 0.012 at $270 \mathrm{~K}$ [104]. The electrical conductivity was $67 \mathrm{~S} \cdot \mathrm{cm}^{-1}$ for $\mathrm{SrMn}_{0.7} \mathrm{Ru}_{0.3} \mathrm{O}_{3}$, and the $\mathrm{ZT}$ value reached 0.01 at $370 \mathrm{~K}$ [108]. $\mathrm{CaMn}_{0.96} \mathrm{Ta}_{0.04} \mathrm{O}_{3}$ reached an electrical conductivity of $29 \mathrm{~S} \cdot \mathrm{cm}^{-1}$ and a $\mathrm{ZT}$ value of 0.05 at $1000 \mathrm{~K}$ [105]. $\mathrm{CaMn}_{0.98} \mathrm{Nb}_{0.02} \mathrm{O}_{3}$ have a S of $-240 \mu \mathrm{V} \cdot \mathrm{K}^{-1}, \sigma$ of $31 \mathrm{~S} \cdot \mathrm{cm}^{-1}$ and $\mathrm{k}$ of $0.8 \mathrm{~W} \cdot \mathrm{m}^{-1} \cdot \mathrm{K}^{-1}$ at $1070 \mathrm{~K}$, leading a ZT values of 0.32 at $1070 \mathrm{~K}$ [107]. However, the significant enhancement of $Z \mathrm{~T}$ value to 0.32 was mainly attributed to low thermal conductivity, caused by phonon scattering from the nanosized twinned domains or the porous morphology [107]. In short, the B-site doping can also serve the purpose of improving the electrical conductivity, but it is not as effective as A-site doping.

\subsubsection{Reducing Thermal Conductivity}

The thermal conductivity of $\mathrm{AMnO}_{3}$ can be decoupled from electrical conductivity by introducing phonon scattering, which was realized by grain boundary [107], lattice distortion [94,95,102], and orbital fluctuation in the paramagnetic phase [110].

For example, $\mathrm{CaMn}_{0.98} \mathrm{Nb}_{0.02} \mathrm{O}_{3}$ has a $\mathrm{k}$ of $0.8 \mathrm{~W} \cdot \mathrm{m}^{-1} \cdot \mathrm{K}^{-1}$ at $1070 \mathrm{~K}$, caused by higher phonon scattering from the nanosized twinned domains or the porous morphology, in which a ZT value of 0.32 at $1070 \mathrm{~K}$ was obtained [107]. Additionally, chemical substitution can result in local lattice distortions linked with quasi-static $\mathrm{Mn}^{3+}$ ions, therefore suppressing the lattice thermal conductivity $[94,95,102]$. For instance, $\mathrm{K}$ of $\mathrm{Ca}_{1-\mathrm{x}} \mathrm{Pr}_{\mathrm{x}} \mathrm{MnO}_{2.98}$ decreased from 2.1 to $1.5 \mathrm{~W} \cdot \mathrm{m}^{-1} \cdot \mathrm{K}^{-1}$ at $\sim 1100 \mathrm{~K}$, when $\mathrm{x}$ varied from 0 to 0.15 [94]; $\mathrm{K}$ of $\mathrm{CaMn}_{1-\mathrm{x}} \mathrm{Mo}_{\mathrm{x}} \mathrm{O}_{3}$ decreased from 2.7 to $1.3 \mathrm{~W} \cdot \mathrm{m}^{-1} \cdot \mathrm{K}^{-1}$ at $300 \mathrm{~K}$, when $\mathrm{x}$ increased from 0.07 to 0.15 [102]; $\mathrm{k}$ of $\mathrm{CaMnO}_{3}$ decreased from 3.6 to $\sim 1.7 \mathrm{~W} \cdot \mathrm{m}^{-1} \cdot \mathrm{K}^{-1}$ at $300 \mathrm{~K}$, when Ca was substituted with $\mathrm{Yb}$ [95] and Ho [95]. Moreover, Mo in $\mathrm{Sr}\left(\mathrm{Mn}_{1-\mathrm{x}} \mathrm{Mo}_{\mathrm{x}}\right) \mathrm{O}_{3}$ introduces orbital fluctuation in the paramagnetic phase, leading to scattering the acoustic phonons, which results in a reduction of the $\mathrm{k}$ from 6.1 to $5 \mathrm{~W} \cdot \mathrm{m}^{-1} \cdot \mathrm{K}^{-1}$ at $390 \mathrm{~K}$, when $\mathrm{x}$ increased from 0 to 0.025 [110].

In short, thermal conductivity is dominated by lattice thermal conductivity for $\mathrm{AMnO}_{3}[107,110]$, and the results showed that phonon scattering by nano-engineering is relatively more effective at suppressing the lattice thermal conductivity [107]. 


\subsection{Cobalt (Co) as B-Site $\left(\mathrm{ACoO}_{3}\right)$}

The reported ZT as a function of temperature when Co was used as B-site $\left(\mathrm{ACoO}_{3}\right)$ was presented in Figure 8. Normally, the rare earth elements (i.e., $\operatorname{Pr}[113-115], \mathrm{Ho}$ [114,121], Nd [113-115], Tb [115], Sm [113,114], Gd [113,114], Dy [114,115], and La [122-129]) were used as A-site elements. The electrical conductivity increased with increasing ionic radii of the rare earth cations. The degree of distortion of the structure determines the onset of the electronic localization-delocalization transition. With a given $\mathrm{R}^{3+}$ size, the $\mathrm{CoO}_{6}$ octahedron is tilted in order to optimize $\mathrm{R}-\mathrm{O}$ bond distances, resulting in a deviation of the Co-O-Co angles from $180^{\circ}$, which determines the degree of overlapping of the cobalt $3 \mathrm{~d}$ and oxygen $2 \mathrm{p}$ orbitals. Large rare-earth ions cause the $\mathrm{Co}-\mathrm{O}-\mathrm{Co}$ bonds to straighten out and become closer to $180^{\circ}$. The Co $3 \mathrm{~d}$ and O $2 \mathrm{p}$ orbital overlap increases as the Co-O-Co angles become closer to $180^{\circ}$, and this structural change leads to the observed rare-earth element dependence of the electronic behavior of $\mathrm{RCoO}_{3}$ [113-115].

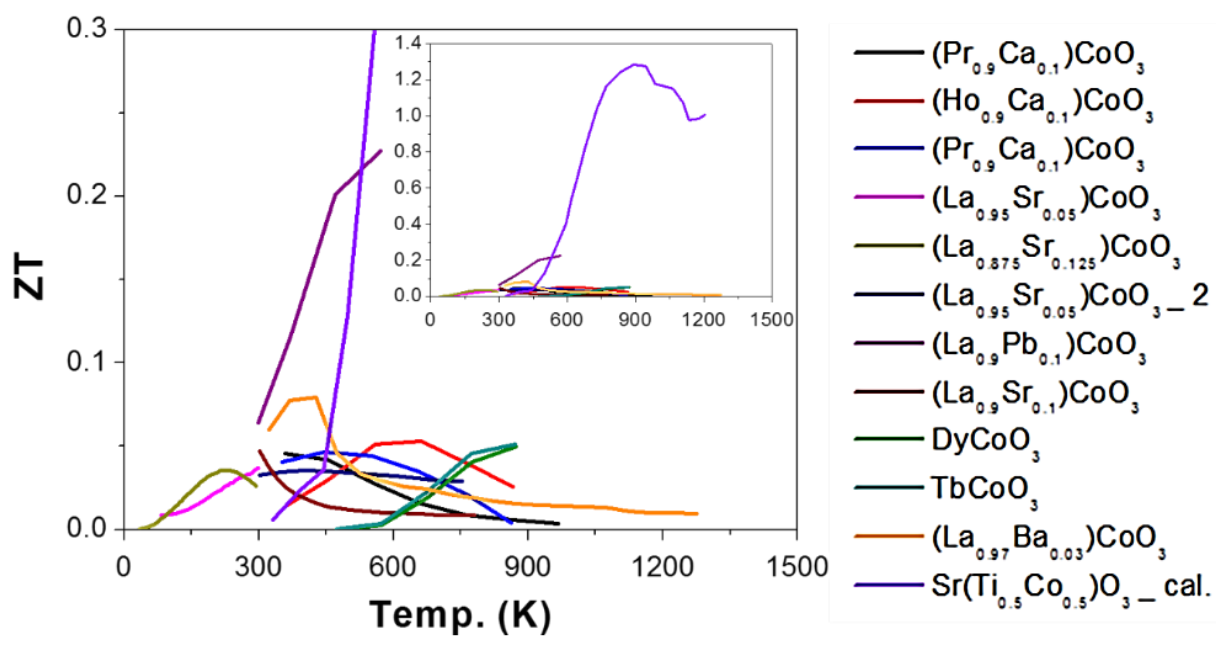

Figure 8. $\mathrm{ZT}$ value of $\mathrm{ACoO}_{3}$ based oxide perovskite materials, all the materials are p-type semiconductors. The symbol "cal." means the results come from the calculation.

For example, Hashimoto et al. reported $\mathrm{Pr}, \mathrm{Nd}, \mathrm{Tb}$, and Dy as A-site in cobalt oxide $\mathrm{RCoO}_{3}(\mathrm{R}=\mathrm{Pr}$, $\mathrm{Nd}, \mathrm{Tb}, \mathrm{Dy})$ ceramics [115]. The electrical conductivity increased with increasing ionic radii of the rare earth cations (ionic radii: $\mathrm{Pr}^{3+}>\mathrm{Nd}^{3+}>\mathrm{Tb}^{3+}>\mathrm{Dy}^{3+}$ ), where the electrical conductivity increased from 180 to $400 \mathrm{~S} \cdot \mathrm{cm}^{-1}$ at $873 \mathrm{~K}$, when A-site changed from $\mathrm{Dy}\left(\mathrm{DyCoO}_{3}\right)$ to $\operatorname{Pr}\left(\mathrm{PrCoO}_{3}\right)$ [115]. However, the highest $\mathrm{ZT}$ value of 0.05 was obtained for $\mathrm{DyCoO}_{3}$ at $873 \mathrm{~K}$ with $\mathrm{S}$ of about $80 \mu \mathrm{V} \cdot \mathrm{K}^{-1}$ and $\mathrm{k}$ of $1.6 \mathrm{~W} \cdot \mathrm{m}^{-1} \cdot \mathrm{K}^{-1}$ [115]. Moon et al. presented the TE properties of $\left(\mathrm{R}_{0.9} \mathrm{Ca}_{0.1}\right) \mathrm{CoO}_{3}(\mathrm{R}=\mathrm{Gd}, \mathrm{Sm}, \mathrm{Nd}$, $\operatorname{Pr}$ [113]. The results showed that electrical conductivity of samples increased sharply with increasing the ionic radius of the rare-earth element $\left(\mathrm{Pr}>\mathrm{Nd}>\mathrm{Sm}>\mathrm{Gd}\right.$ ). The $\sigma$ changed from 23 to $210 \mathrm{~S} \cdot \mathrm{cm}^{-1}$, when the samples changed from $\left(\mathrm{Gd}_{0.9} \mathrm{Ca}_{0.1}\right) \mathrm{CoO}_{3}$ to $\left(\mathrm{Pr}_{0.9} \mathrm{Ca}_{0.1}\right) \mathrm{CoO}_{3}$ [113]. A $\mathrm{ZT}$ value of 0.047 was achieved at $358 \mathrm{~K}$ for $\left(\mathrm{Pr}_{0.9} \mathrm{Ca}_{0.1}\right) \mathrm{CoO}_{3}$ with $\sigma$ of $210 \mathrm{~S} \cdot \mathrm{cm}^{-1}$ and $\mathrm{S}$ of about $108 \mu \mathrm{V} \cdot \mathrm{K}^{-1}$ [113].

In addition, similar phenomenon were observed when the ionic radius of dopants $\left(\mathrm{Ca}^{2+}<\mathrm{Sr}^{2+}<\mathrm{Ba}^{2+}\right)$ increased for $\left(\operatorname{Pr}_{0.9} \mathrm{M}_{0.1}\right) \mathrm{CoO}_{3}(\mathrm{M}=\mathrm{Ca}, \mathrm{Sr}, \mathrm{Ba})$. The electrical conductivity increased from 350 to $420 \mathrm{~S} \cdot \mathrm{cm}^{-1}$, when varied from $\left(\operatorname{Pr}_{0.9} \mathrm{Ca}_{0.1}\right) \mathrm{CoO}_{3}$ to $\left(\operatorname{Pr}_{0.9} \mathrm{Ba}_{0.1}\right) \mathrm{CoO}_{3}[114]$.

Furthermore, the electrical conductivity of $\mathrm{LaCoO}_{3}$ normally increases with increasing temperature. For instance, $\sigma$ increased from 14 to $1230 \mathrm{~S} \cdot \mathrm{cm}^{-1}$ for $\mathrm{La}_{0.95} \mathrm{Sr}_{0.05} \mathrm{CoO}_{3}$, when temperature increased from 300 to $750 \mathrm{~K}$ ) [124]. This temperature dependent conduction behaviors of $\mathrm{La}_{0.95} \mathrm{Sr}_{0.05} \mathrm{CoO}_{3}$ were explained regarding small polaron hopping mechanism with positive polarons $\left(\mathrm{Co}^{4+} \mathrm{Co}^{3+}\right)$ as transport carriers [124]. Increase of $\sigma$ with increasing temperature was attributed to the increase of the $\left(\mathrm{Co}^{4+} \mathrm{Co}^{3+}\right)$ concentration on the Co sites [124]. 


\subsubsection{Chemical Doping in A-Site}

The strategy of A-site doping was applied to tune the electrical conductivity further. $\mathrm{LaCoO}_{3}$ was investigated with $\mathrm{Sr}$ [122-125], $\mathrm{Pb}$ [126], $\mathrm{Na}$ [126], and $\mathrm{Ba}$ [128] used as A-site dopant. Sr-doped $\mathrm{LaCoO}_{3}$ (i.e., $\mathrm{La}_{1-\mathrm{x}} \mathrm{Sr}_{\mathrm{x}} \mathrm{CoO}_{3}, 0 \leq \mathrm{x} \leq 0.2$ ) was investigated. The electrical conductivity enhanced from $\sim 2$ to $296 \mathrm{~S} \cdot \mathrm{cm}^{-1}$, when $x$ changed from 0 to 0.2 at $300 \mathrm{~K}$ [123-125]. A ZT value of $\mathrm{La}_{0.9} \mathrm{Sr}_{0.1} \mathrm{CoO}_{3}$ obtained was 0.046 at $300 \mathrm{~K}$ with $\sigma$ of $\sim 180 \mathrm{~S} \cdot \mathrm{cm}^{-1}, \mathrm{~S}$ of $\sim 120 \mu \mathrm{V} \cdot \mathrm{K}^{-1}$, and $\mathrm{K}$ of $1.45 \mathrm{~W} \cdot \mathrm{m}^{-1} \cdot \mathrm{K}^{-1}$ [125]; and a ZT value of 0.18 was achieved for $\mathrm{La}_{0.95} \mathrm{Sr}_{0.05} \mathrm{CoO}_{3}$ with $\mathrm{S}$ of $\sim 710 \mu \mathrm{V} \cdot \mathrm{K}^{-1}$ and $\mathrm{K}$ of $3.7 \mathrm{~W} \cdot \mathrm{m}^{-1} \cdot \mathrm{K}^{-1}$ [123]. $\mathrm{Pb}$ and $\mathrm{Na}$ were used as A-site dopant for $\mathrm{LaCoO}_{3}$ with composition $\mathrm{La}_{0.9} \mathrm{R}_{0.1} \mathrm{CoO}_{3}(\mathrm{R}=\mathrm{Pb}, \mathrm{Na})$. The electrical conductivity for undoped polycrystalline $\mathrm{LaCoO}_{3}$ was $25 \mathrm{~S} \cdot \mathrm{cm}^{-1}$, and was enhanced to 250 and $33 \mathrm{~S} \cdot \mathrm{cm}^{-1}$ at $575 \mathrm{~K}$, when doped with $\mathrm{Pb}$ (i.e., $\mathrm{La}_{0.9} \mathrm{~Pb}_{0.1} \mathrm{CoO}_{3}$ ) and $\mathrm{Na}$ (i.e., $\mathrm{La}_{0.9} \mathrm{Na}_{0.1} \mathrm{CoO}_{3}$ ), respectively [126]. The thermal conductivity of $\mathrm{LaCoO}_{3}, \mathrm{La}_{0.9} \mathrm{~Pb}_{0.1} \mathrm{CoO}_{3}$, and $\mathrm{La}_{0.9} \mathrm{Na}_{0.1} \mathrm{CoO}_{3}$ were $1.83,1.55$, and $0.9 \mathrm{~W} \cdot \mathrm{m}^{-1} \cdot \mathrm{K}^{-1}$, respectively [126]. A ZT value of 0.23 was achieved at $575 \mathrm{~K}$ for $\mathrm{La}_{0.9} \mathrm{~Pb}_{0.1} \mathrm{CoO}_{3}$ with $\mathrm{S}$ of $\sim 110 \mu \mathrm{V} \cdot \mathrm{K}^{-1}$, which was attributed to both increasing the electrical conductivity and suppressing the lattice thermal conductivity [126]. The electronic part of the thermal conductivity contribution was estimated using the Wiedemann-Franz law in $\mathrm{La}_{1-\mathrm{x}} \mathrm{R}_{\mathrm{x}} \mathrm{CoO}_{3}$ to be about $1 \%$ in $\mathrm{LaCoO}_{3}, 3 \%$ in $\mathrm{La}_{0.9} \mathrm{Na}_{0.1} \mathrm{CoO}_{3}$, and $31 \%$ in $\mathrm{La}_{0.9} \mathrm{~Pb}_{0.1} \mathrm{CoO}_{3}$ of the total thermal conductivity at $575 \mathrm{~K}$, which shows that lattice thermal conductivity plays a major role in these samples [126]. The overall suppression of the total thermal conductivity upon $\mathrm{Pb}$ and $\mathrm{Na}$ substitution mainly comes from the reduction of the lattice thermal conductivity, possibly through the lattice strain induced by the atomic disorder at the A-site of the perovskite structure and the mixed valency at the Co-site [126].

Additionally, Moon et al. investigated TE properties of $\left(\mathrm{Ho}_{1-\mathrm{x}} \mathrm{Ca}_{\mathrm{x}}\right) \mathrm{CoO}_{3}$. The electrical conductivity was enhanced from $1 \times 10^{-4} \mathrm{~S} \cdot \mathrm{cm}^{-1}$ to $2 \mathrm{~S} \cdot \mathrm{cm}^{-1}$ when $\mathrm{x}$ changed from 0 to 0.1 at $573 \mathrm{~K}$. The highest ZT value obtained was 0.051 at $573 \mathrm{~K}$ for $\mathrm{Ho}_{0.9} \mathrm{Ca}_{0.1} \mathrm{CoO}_{3}$ with $\mathrm{S}$ of about $210 \mu \mathrm{V} \cdot \mathrm{K}^{-1}$ and $\mathrm{K}$ of $0.75 \mathrm{~W} \cdot \mathrm{m}^{-1} \cdot \mathrm{K}^{-1}[121]$.

\subsubsection{Chemical Doping in B-Site}

Mn [127] and Ni [129] were used as a B-site dopant in $\mathrm{LaCoO}_{3}$. For example, the electrical conductivity reached $5 \mathrm{~S} \cdot \mathrm{cm}^{-1}$ at $400 \mathrm{~K}$ for $\mathrm{LaCo}_{0.99} \mathrm{Mn}_{0.01} \mathrm{O}_{3}$ [127]. The carrier concentration increases from $6.1 \times 10^{14}$ to $2.6 \times 10^{17} \mathrm{~cm}^{-3}$ for $\mathrm{YCo}_{1-\mathrm{x}} \mathrm{Ni}_{\mathrm{x}} \mathrm{O}_{3}$, leading to increasing in electrical conductivity from 0.0015 to $0.011 \mathrm{~S} \cdot \mathrm{cm}^{-1}$ at room temperature, when $x$ changes from 0 to 0.07 [129].

\subsubsection{Reducing Thermal Conductivity}

Suppressing the lattice thermal conductivity was applied to decouple $\sigma$ and $\kappa$, which was realized by chemical substitution. The chemical substitution can induce lattice disorder, lattice strain, or mass disorder, leading to phonon scattering $[122,126,128]$. In the reported studies, the effect of A-site doping (e.g., $\mathrm{Sr}$ [122], $\mathrm{Pb}$ [126], $\mathrm{Na}$ [126], $\mathrm{Ba}$ [128]) on lattice thermal conductivity of $\mathrm{ACoO}_{3}$ was investigated, while the B-site doping was barely discussed.

For instance, single crystal $\mathrm{La}_{0.82} \mathrm{Sr}_{0.18} \mathrm{CoO}_{3}$ has a lower $\mathrm{k}$ of $1 \mathrm{~W} \cdot \mathrm{m}^{-1} \cdot \mathrm{K}^{-1}$ compared to $\sim 5 \mathrm{~W} \cdot \mathrm{m}^{-1} \cdot \mathrm{K}^{-1}$ for $\mathrm{LaCoO}_{3}$ at $60 \mathrm{~K}$, due to lattice disorder caused by temperature and/or doping-induced spin-state transitions of the $\mathrm{Co}$ ions [122]. Moreover, the thermal conductivity of $\mathrm{LaCoO}_{3}$ can be tuned by $\mathrm{Na}$ and $\mathrm{Pb}$ substitution of $\mathrm{La}$. The thermal conductivity of $\mathrm{LaCoO}_{3}, \mathrm{La}_{0.9} \mathrm{~Pb}_{0.1} \mathrm{CoO}_{3}$, and $\mathrm{La}_{0.9} \mathrm{Na}_{0.1} \mathrm{CoO}_{3}$ were $1.83,1.55$, and $0.9 \mathrm{~W} \cdot \mathrm{m}^{-1} \cdot \mathrm{K}^{-1}$, respectively, which may be attributed to the lattice strain induced by the atomic disorder at the A-site of the perovskite structure and the mixed valency at the Co-site [126]. The thermal conductivity of $\mathrm{LaCoO}_{3}$ can also be suppressed by Ba substitution. The thermal conductivity of $\mathrm{La}_{1-x} \mathrm{Ba}_{\mathrm{x}} \mathrm{CoO}_{3}(\mathrm{x}=0.01,0.03,0.05)$ was about $0.5-0.6 \mathrm{~W} \cdot \mathrm{m}^{-1} \cdot \mathrm{K}^{-1}$ at $320 \mathrm{~K}$ [128], while the thermal conductivity of $\mathrm{LaCoO}_{3}$ is about $2.5 \mathrm{~W} \cdot \mathrm{m}^{-1} \cdot \mathrm{K}^{-1}$ in the same temperature range [126]. This phenomenon can be explained by mass disorder scattering of phonons, reducing the lattice part of the thermal conductivity, resulting in a ZT value of 0.08 in the $400 \mathrm{~K}$ range for $\mathrm{La}_{0.97} \mathrm{Ba}_{0.03} \mathrm{CoO}_{3}$ with $\sigma$ of $350 \mathrm{~S} \cdot \mathrm{cm}^{-1}$ and $\mathrm{S}$ of $\sim 220 \mu \mathrm{V} \cdot \mathrm{K}^{-1}[128]$. 
In short, the A-site dopant is more effective than B-site dopant in improving the carrier concentration and electrical conductivity. However, high ZT of 0.23 was achieved with the combination of high electrical conductivity and low thermal conductivity [126].

2.4. Other Elements, Including Iron (Fe), Nickel (Ni), Tin (Sn), Lead (Pb), Bismuth (Bi), Molybdenum (Mo), Ruthenium $(R u)$, and Uranium $(U)$ as $B$-Site $\left(A B O_{3}\right)$

\subsubsection{Fe as B-Site $\left(\mathrm{AFeO}_{3}\right)$}

The reported ZT when Fe was used as B-site was presented in Figure 9. $\mathrm{LaFeO}_{3}$ was investigated for TE application. To improve the electrical conductivity, Sr [134,136] and Pr [135] were used as A-site dopant or substitution. The electrical conductivity was increased from 21 to $158 \mathrm{~S} \cdot \mathrm{cm}^{-1}$ for $\mathrm{La}_{1-x} \mathrm{Sr}_{x} \mathrm{FeO}_{3}$, when $\mathrm{x}$ changed from 0.05 to 0.25 , and a $\mathrm{ZT}$ value of 0.076 at $1273 \mathrm{~K}$ was achieved when $\mathrm{x}=0.05\left(\mathrm{La}_{0.95} \mathrm{Sr}_{0.05} \mathrm{FeO}_{3}\right)$ with $\mathrm{S}$ of $228 \mu \mathrm{V} \cdot \mathrm{K}^{-1}, \sigma$ of $21 \mathrm{~S} \cdot \mathrm{cm}^{-1}$, and $\mathrm{k}$ of $1.85 \mathrm{~W} \cdot \mathrm{m}^{-1} \cdot \mathrm{K}^{-1}$ [136].

Double perovskite $\mathrm{A}_{2} \mathrm{FeMoO}_{6}$ was also studied for thermoelectric application. For example, Sugahara et al. reported a ZT value of 0.14 at $1250 \mathrm{~K}$ for $\mathrm{Ca}_{2} \mathrm{FeMoO}_{6}$ with $\mathrm{S}$ of $-108 \mu \mathrm{V} \cdot \mathrm{K}^{-1}, \sigma$ of $270 \mathrm{~S} \cdot \mathrm{cm}^{-1}$, and $\mathrm{K}$ of $3.1 \mathrm{~W} \cdot \mathrm{m}^{-1} \cdot \mathrm{K}^{-1}$ [137]. Additionally, they also presented a ZT value of 0.24 at $1250 \mathrm{~K}$ for $\mathrm{Sr}_{1.6} \mathrm{~K}_{0.4} \mathrm{FeMoO}_{6}$ with $\mathrm{S}$ of $48 \mu \mathrm{V} \cdot \mathrm{K}^{-1}, \sigma$ of $600 \mathrm{~S} \cdot \mathrm{cm}^{-1}$, and $\mathrm{k}$ of $3.1 \mathrm{~W} \cdot \mathrm{m}^{-1} \cdot \mathrm{K}^{-1}$ [138]. Sahnoun et al. investigated electrical and TE properties of $\mathrm{Ba}_{2} \mathrm{FeMoO}_{6}$ by Wien2K calculations and Boltzmann transport theory in the temperature range of 200 to $1100 \mathrm{~K}$ [139]. Their results revealed that $\mathrm{Ba}_{2} \mathrm{FeMoO}_{6}$ could achieve a $\mathrm{ZT}$ value of 0.98 at $1000 \mathrm{~K}$ with enhanced electrical conductivity [139].

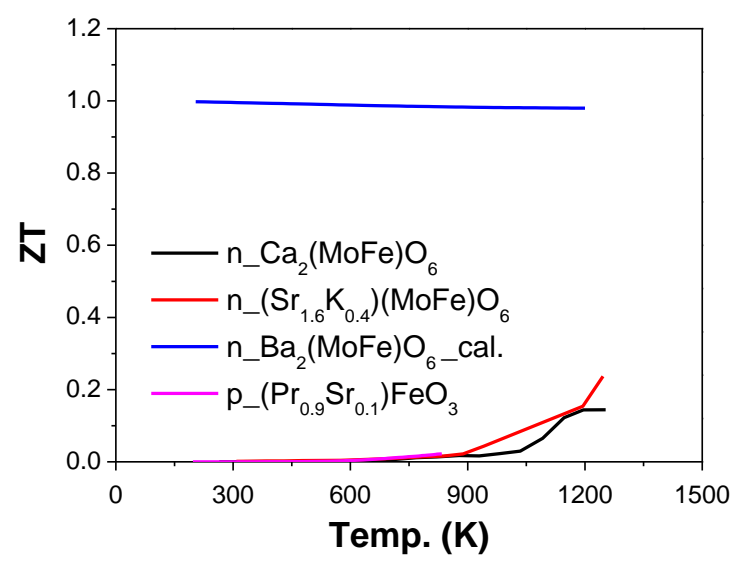

Figure 9. $\mathrm{ZT}$ value of $\mathrm{AFeO}_{3}$ based oxide perovskite materials, the majority carrier types (n or $\mathrm{p}$ ) were marked in the legend. The symbol "cal." means the results come from the calculation.

\subsection{2. $\mathrm{Ni}$ as $\mathrm{B}$-Site $\left(\mathrm{ANiO}_{3}\right)$}

The TE properties of $\mathrm{LaNi}_{1-\mathrm{x}} \mathrm{Cu}_{\mathrm{x}} \mathrm{O}_{3-\delta}(0.2<\mathrm{x}<0.5)$ was investigated. Electrical conductivity of $790 \mathrm{~S} \cdot \mathrm{cm}^{-1}$ was obtained at $\mathrm{x}=0.3$. Additionally, $\mathrm{Cu}$ doping into $\mathrm{Ni}$ sites in $\mathrm{LaNi}_{1-x} \mathrm{CuxO}_{3-\delta}$ solid solutions can suppress the formation of intermediate secondary phases (the deoxidized $\mathrm{La}_{4} \mathrm{Ni}_{3} \mathrm{O}_{10}$ and $\mathrm{La}_{3} \mathrm{Ni}_{2} \mathrm{O}_{7}$ phases) using donor doping effects. Since the increase in the charge valence of a metal ion can be counterbalanced by an equivalent decrease in the formation of oxygen vacancies, $\mathrm{Cu}$ doping into $\mathrm{Ni}$ ion sites can prohibit the formation of oxygen vacancies. A power factor of $40 \mu \mathrm{W} \cdot \mathrm{K}^{-2} \cdot \mathrm{m}^{-1}$ was achieved for $\mathrm{LaNi}_{0.8} \mathrm{Cu}_{0.2} \mathrm{O}_{3}$ at $600 \mathrm{~K}$ [140].

\subsection{3. $\mathrm{Sn}$ as $\mathrm{B}-\mathrm{Site}\left(\mathrm{ASnO}_{3}\right)$}

The reported ZT when Sn was used as B-site was presented in Figure 10. So far, there are several studies that have reported the A-site chemical substitution (e.g., Ba [143] and $\mathrm{Sr}$ [144]) to enhance $\sigma$. For examples, La was used as A-site dopant in $\mathrm{Ba}_{1-\mathrm{x}} \mathrm{La}_{\mathrm{x}} \mathrm{SnO}_{3}$ with $\mathrm{x}=0.002,0.005,0.008$, and 0.010 [143]. The electrical conductivity increased from 120 to $350 \mathrm{~S} \cdot \mathrm{cm}^{-1}$, when $\mathrm{x}$ changed from 0.002 
to 0.010 . A ZT value reached 0.1 at $1073 \mathrm{~K}$ for $\mathrm{Ba}_{0.998} \mathrm{La}_{0.002} \mathrm{SnO}_{3}$ [143]. The electrical conductivity of $\mathrm{Sr}_{1-\mathrm{x}} \mathrm{La}_{\mathrm{x}} \mathrm{SnO}_{3}$ increased from 4 to $120 \mathrm{~S} \cdot \mathrm{cm}^{-1}$, when $\mathrm{x}$ changed from 0.01 to 0.03 [144]. A ZT value of 0.05 was achieved at $1073 \mathrm{~K}$ for $\mathrm{Sr}_{0.99} \mathrm{La}_{0.01} \mathrm{SnO}_{3}$ [144].

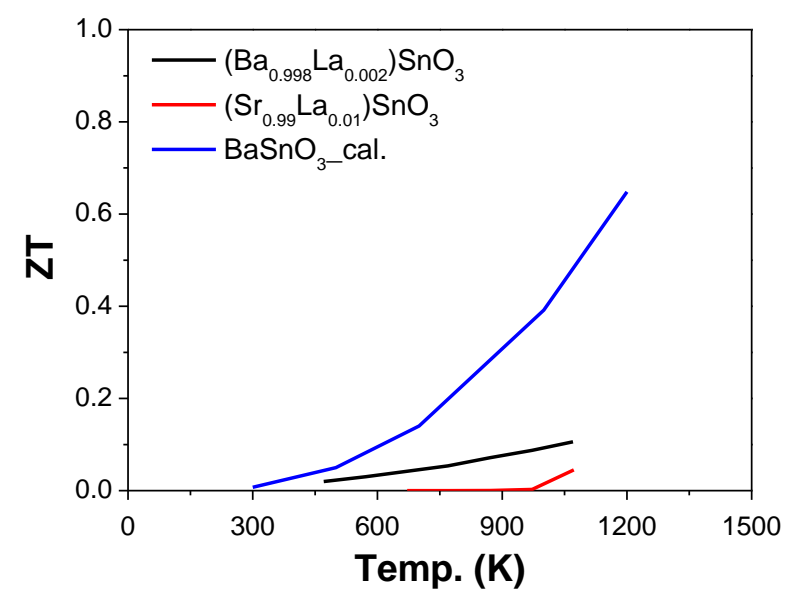

Figure 10. $\mathrm{ZT}$ value of $\mathrm{ASnO}_{3}$ based oxide perovskite materials, all the materials are n-type semiconductors. The symbol "cal." means the results come from the calculation.

Additionally, the thermoelectric transport properties of $\mathrm{BaSnO}_{3}$ were calculated using density functional theory combined with Boltzmann transport theory, where the electrical conductivity of $\mathrm{BaSnO}_{3}$ is improved dramatically after doping, owing to small effective mass and high mobility [145]. The power factor can reach $1.5 \times 10^{-3} \mathrm{~W} \cdot \mathrm{m}^{-1} \cdot \mathrm{K}^{-2}$ at $1200 \mathrm{~K}$ with a carrier concentration of $1.6 \times 10^{19}$ $\mathrm{cm}^{-3}$, giving rise to a ZT value of 0.65 at $1200 \mathrm{~K}$ by calculation [145].

\subsection{4. $\mathrm{Pb}$ as B-Site $\left(\mathrm{APbO}_{3}\right)$}

The $\mathrm{ZT}$ values as a function of temperature for oxide perovskite materials, when $\mathrm{Pb}$ was used as B-site, were showed in Figure 11A. Ba has been used as A-site dopant for $\mathrm{Sr}_{1-x} \mathrm{Ba}_{\mathrm{x}} \mathrm{PbO}_{3}(0<\mathrm{x}<1)$. The electrical conductivity increased from 20 to $1585 \mathrm{~S} \cdot \mathrm{cm}^{-1}$, when $\mathrm{x}$ changed from 0 to 1 , a ZT of 0.13 was achieved at $673 \mathrm{~K}$ when $\mathrm{x}=0.4\left(\mathrm{Sr}_{0.6} \mathrm{Ba}_{0.4} \mathrm{PbO}_{3}\right)[146,147]$. Additionally, $\mathrm{Bi}$ was used as B-site dopant for $\mathrm{Sr}_{0.7} \mathrm{Ba}_{0.3} \mathrm{~Pb}_{1-\mathrm{x}} \mathrm{Bi}_{\mathrm{x}} \mathrm{O}_{3}$ with $0.00 \leq \mathrm{x} \leq 0.25$, where the electrical conductivity increased from 250 to $400 \mathrm{~S} \cdot \mathrm{cm}^{-1}$, when $x$ changed from 0 to 0.05 [148].
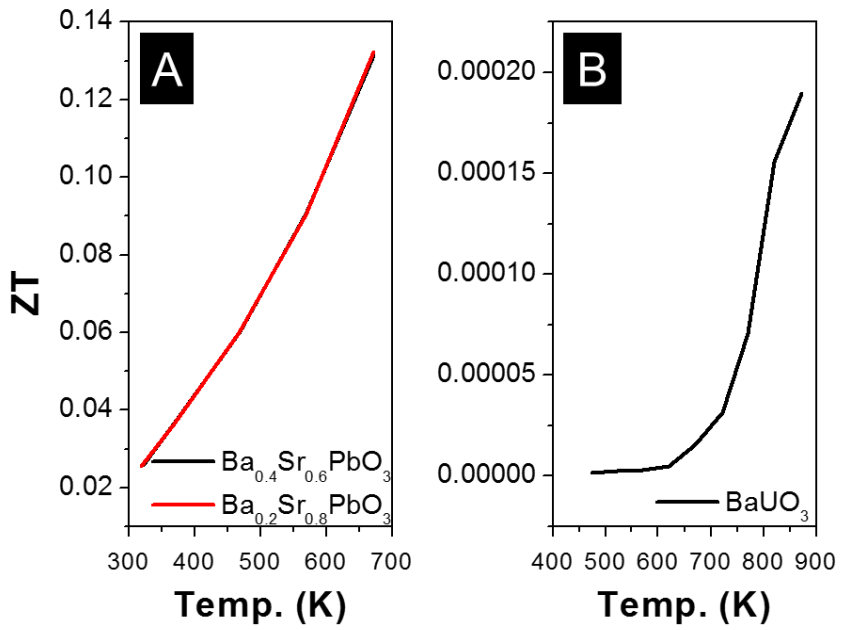

Figure 11. $\mathrm{ZT}$ value of $(\mathbf{A}) \mathrm{APbO}_{3}$ and $(\mathbf{B}) \mathrm{AUO}_{3}$ based oxide perovskite materials, all the materials are n-type semiconductors. 


\subsection{5. $\mathrm{Bi}$ as $\mathrm{B}$-Site $\left(\mathrm{ABiO}_{3}\right)$}

The TE properties of p-type $\mathrm{BaBi}_{1-\mathrm{x}} \mathrm{Sb}_{\mathrm{x}} \mathrm{O}_{3}(0.0 \leq \mathrm{x} \leq 0.5)$ was investigated at temperatures between $423 \mathrm{~K}$ and $973 \mathrm{~K}$. The electrical conduction mechanism is explained by hopping of small polaronic holes localized on the pentavalent cations, and substitution of $\mathrm{Bi}$ with $\mathrm{Sb}$ would decrease the electrical conductivity but improve the Seebeck coefficient. The electrical conduction in the $\mathrm{BaBiO}_{3}$ is due to hopping of small polaronic $6 s$ holes from $\mathrm{Bi}^{5+}\left(6 \mathrm{~s}^{0}\right)$ to $\mathrm{Bi}^{3+}\left(6 \mathrm{~s}^{2}\right)$ with the aid of electron-phonon coupling. Substitution of $\mathrm{Bi}^{5+}$ with $\mathrm{Sb}^{5+}$ causes the $6 \mathrm{~s}$ holes to decrease, leading to smaller electrical conductivity and a larger Seebeck coefficient as the $\mathrm{Sb}$ content increases. As a result, $\mathrm{Sb}$ doping does not enhance the TE properties of $\mathrm{BaBiO}_{3}$, a power factor of $30 \mu \mathrm{W} \cdot \mathrm{m}^{-1} \cdot \mathrm{K}^{-2}$ was obtained for Sb-undoped $\mathrm{BaBiO}_{3}$ at $773 \mathrm{~K}[150]$.

\subsubsection{Mo as B-Site $\left(\mathrm{AMoO}_{3}\right)$}

Kurosaki et al. prepared a polycrystalline sample of perovskite-type barium molybdate $\left(\mathrm{BaMoO}_{3}\right)$, and a $\mathrm{ZT}$ value of 0.015 was obtained at $470 \mathrm{~K}$ with $\mathrm{S}$ of $\sim-30 \mu \mathrm{V} \cdot \mathrm{K}^{-1}$ [151]. Oba et al. investigated thermoelectric properties of $\mathrm{V}, \mathrm{Sr}$, and $\mathrm{Mn}$ substituted $\mathrm{Sr}_{2} \mathrm{FeMoO}_{6}$ systems. For $\mathrm{Sr}_{1.4} \mathrm{Ba}_{0.6} \mathrm{Fe}_{1-z} \mathrm{Mn}_{\mathrm{z}} \mathrm{Mo}_{0.8} \mathrm{~V}_{0.2} \mathrm{O}_{6}$ samples, the Seebeck coefficient increased with increasing $\mathrm{Mn}$ substitution. The power factor reached $83.2 \mu \mathrm{W} \cdot \mathrm{m}^{-1} \cdot \mathrm{K}^{-2}$ in the composition of $\mathrm{Sr}_{1.4} \mathrm{Ba}_{0.6} \mathrm{Fe}_{0.8} \mathrm{Mn}_{0.2} \mathrm{Mo}_{0.8} \mathrm{~V}_{0.2} \mathrm{O}_{6}$ at $973 \mathrm{~K}$ [152].

\subsection{7. $\mathrm{Ru}$ as B-Site $\left(\mathrm{ARuO}_{3}\right)$}

Several studies reported the TE properties of $\mathrm{ARuO}_{3}$ based materials. For example, polycrystalline $\mathrm{SrRuO}_{3}$ was studied, and a $\mathrm{ZT}$ value of 0.03 was obtained at $670 \mathrm{~K}$ with $\mathrm{S}$ of $36 \mu \mathrm{V} \cdot \mathrm{K}^{-1}$ and $\kappa$ of $5.3 \mathrm{~W} \cdot \mathrm{m}^{-1} \cdot \mathrm{K}^{-1}$ [153]. $\mathrm{Sr}_{2} \mathrm{RuYO}_{6}$ and $\mathrm{Sr}_{2} \mathrm{RuErO}_{6}$ were reported to have a $\mathrm{S}$ of -475 and $-400 \mu \mathrm{V} \cdot \mathrm{K}^{-1}$ at room temperature, respectively [154]. Additionally, La was used as A-site dopant for $\left(\mathrm{Sr}_{1-\mathrm{x}} \mathrm{La}_{\mathrm{x}}\right)_{2} \mathrm{ErRuO}_{6}(0<\mathrm{x}<0.3)$. The carrier concentration was enhanced from $9.7 \times 10^{20}$ to $2.2 \times 10^{21} \mathrm{~cm}^{-3}$, when $x$ changed from 0.1 to 0.3 , resulting in the electrical conductivity increased from 0.1 to $1.7 \mathrm{~S} \cdot \mathrm{cm}^{-1}$ at $800 \mathrm{~K}$. A ZT value of $\sim 0.001$ was obtained with $\mathrm{S}$ of $-160 \mu \mathrm{V} \cdot \mathrm{K}^{-1}$ and $\mathrm{k}$ of $7 \mathrm{~mW} \cdot \mathrm{cm}^{-1} \cdot \mathrm{K}^{-1}$ for $\left(\mathrm{Sr}_{0.9} \mathrm{La}_{0.1}\right)_{2} \mathrm{ErRuO}_{6}$ at $800 \mathrm{~K}$ [155].

\subsection{8. $\mathrm{U}$ as B-Site $\left(\mathrm{AUO}_{3}\right)$}

The TE properties of $\mathrm{BaUO}_{3}$ in the temperature range from room temperature to $1000 \mathrm{~K}$ was investigated. A ZT value of 0.0002 was obtained at $880 \mathrm{~K}$ (Figure 11B) with $\mathrm{S}$ of $-270 \mu \mathrm{V} \cdot \mathrm{K}^{-1}, \sigma$ of $0.1 \mathrm{~S} \cdot \mathrm{cm}^{-1}$ and $\mathrm{k}$ of $0.9 \mathrm{~W} \cdot \mathrm{m}^{-1} \cdot \mathrm{K}^{-1}$. The low $\mathrm{k}$ was attributed to its phonon glass property [158].

\section{Hybrid Perovskites}

The ZT values of hybrid perovskite materials reported by different groups were summarized in Figure 12. Hybrid perovskite materials have a relatively high Seebeck coefficient $\left(700 \mu \mathrm{V} \cdot \mathrm{K}^{-1}\right.$ for $\mathrm{CH}_{3} \mathrm{NH}_{3} \mathrm{PbI}_{3}$ at $295 \mathrm{~K}$ ) [160] and low thermal conductivity $\left(0.5 \mathrm{~W} \cdot \mathrm{m}^{-1} \cdot \mathrm{K}^{-1}\right.$ for $\mathrm{CH}_{3} \mathrm{NH}_{3} \mathrm{PbI}_{3}$ at $295 \mathrm{~K}$ ) [160], but the electrical conductivity is relatively low compared to traditional thermoelectric materials. Studies so far have all focused on how to improve the electrical conductivity through photo-induced or chemical doping strategies. Several hybrid perovskite materials-such as $\mathrm{ABI}_{3}\left(\mathrm{~A}=\mathrm{CH}_{3} \mathrm{NH}_{3}(\mathrm{MA}), \mathrm{NH}_{2} \mathrm{CHNH}_{2}(\mathrm{FA})\right.$ and $\left.\mathrm{B}=\mathrm{Sn}, \mathrm{Pb}\right)[33,34,160,161], \mathrm{CsMI}_{3}$ [162], and $\mathrm{C}_{6} \mathrm{H}_{4} \mathrm{NH}_{2} \mathrm{CuBr}_{2} \mathrm{I}$ [35] - were studied theoretically or experimentally for TE application.

The theoretical analysis showed that the ZT value of hybrid perovskite materials could achieve 0.9 for n-type $[33,34,161,162]$ and 1.25 for p-type $[161,162]$ through chemical doping strategies. For example, the thermoelectric behavior of $\mathrm{CH}_{3} \mathrm{NH}_{3} \mathrm{PbI}_{3}$ for a wide range of temperatures and carrier concentrations was theoretically analyzed. The results showed optimal carrier concentration of about $10^{19} \mathrm{~cm}^{-3}$, leading to an electrical conductivity of $160 \mathrm{~S} \cdot \mathrm{cm}^{-1}$ and a calculated Seebeck coefficient of $-238 \mu \mathrm{V} \cdot \mathrm{K}^{-1}$. In combination with a thermal conductivity $\sim 0.3-0.5 \mathrm{~W} \cdot \mathrm{m}^{-1} \cdot \mathrm{K}^{-1}$, this delivers 
ZT of 0.3-0.9 (Figure 13) [33]. Additionally, the TE properties for $\mathrm{CH}_{3} \mathrm{NH}_{3} \mathrm{PbI}_{3}$ were theoretically investigated as a function of carrier concentration based on first-principles calculations. The results showed that $\mathrm{ZT}$ values of 0.9 and 1.25 could be achieved for n-type and p-type tetragonal $\mathrm{CH}_{3} \mathrm{NH}_{3} \mathrm{PbI}_{3}$, respectively, with a carrier concentration of $10^{19} \mathrm{~cm}^{-3}$ at $330 \mathrm{~K}$ [161]. The effect of doping on TE properties of organic-inorganic perovskite iodides $\mathrm{ABI}_{3}\left(\mathrm{~A}=\mathrm{CH}_{3} \mathrm{NH}_{3}(\mathrm{MA}), \mathrm{NH}_{2} \mathrm{CHNH}_{2}\right.$ (FA); $\mathrm{B}=\mathrm{Sn}, \mathrm{Pb}$ ) at $300 \mathrm{~K}$ were analyzed through calculation. The results indicated that $\mathrm{ZT}$ value of 0.44 , $0.45,0.42$, and 0.35 can be achieved for n-type $(\mathrm{MA}) \mathrm{PbI}_{3},(\mathrm{MA}) \mathrm{SnI}_{3},(\mathrm{FA}) \mathrm{PbI}_{3}$, and $(\mathrm{FA}) \mathrm{SnI}_{3}$ at carrier concentrations of $2.3 \times 10^{19}, 3.3 \times 10^{19}, 1.2 \times 10^{19}$, and $5.0 \times 10^{19} \mathrm{~cm}^{-3}$, respectively [34]. Moreover, TE properties of halide perovskite $\mathrm{CsMI}_{3}(\mathrm{M}=\mathrm{Sn}$ and $\mathrm{Pb})$ was investigated by a combination of first-principles calculations and semiclassical Boltzmann transport theory by taking into account both the electron and phonon transport. The calculation showed that the ZT values are up to 0.63 and 0.64 for n-type $\mathrm{CsSnI}_{3}$ and $\mathrm{CsPbI}_{3}$ at $1000 \mathrm{~K}$ with the carrier concentration of $4.2 \times 10^{19}$ and $0.53 \times 10^{19} \mathrm{~cm}^{-3}$, respectively [162].

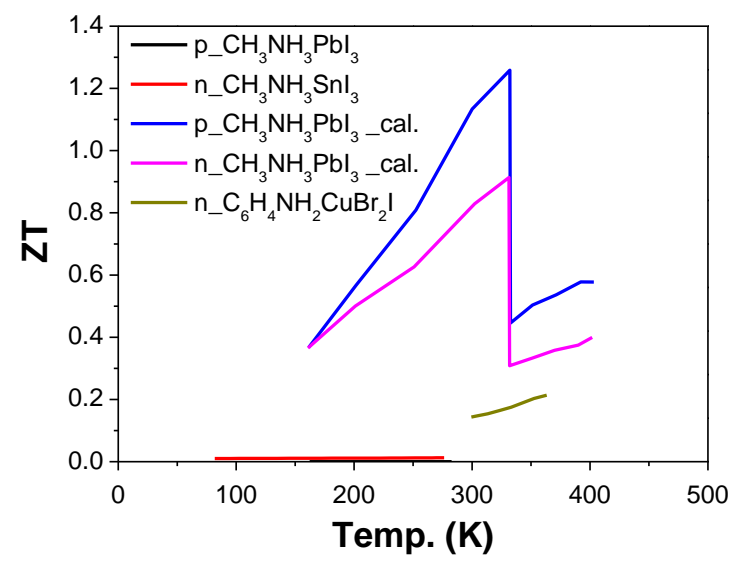

Figure 12. ZT value of hybrid perovskite materials. The majority carrier types (n or p) were marked in the legend. The symbol "cal." means the results come from the calculation.

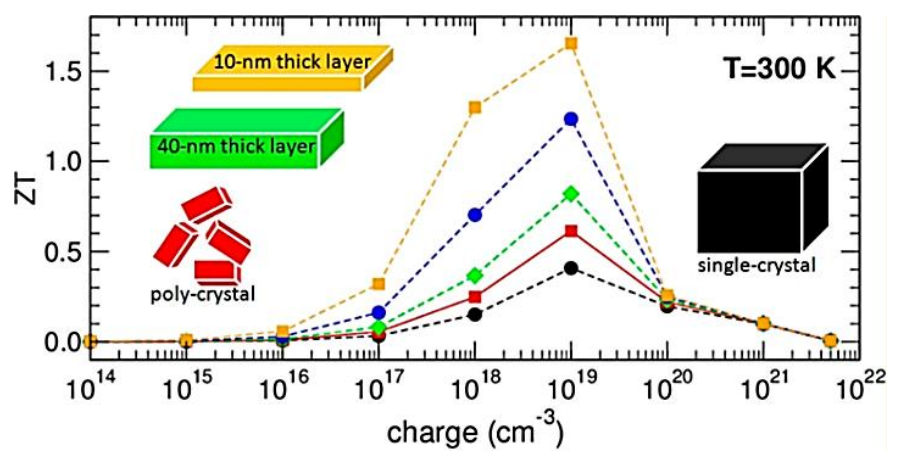

Figure 13. ZT vs. charge concentration for electron-doped $\mathrm{CH}_{3} \mathrm{NH}_{3} \mathrm{PbI}_{3}$, calculated at $300 \mathrm{~K}$. Black dots and red squares correspond to single crystal and polycrystal $\mathrm{CH}_{3} \mathrm{NH}_{3} \mathrm{PbI}_{3}$, respectively; the other symbols are for mimicking ZT value in 2D wells of thickness $\mathrm{L}=40 \mathrm{~nm}$ (green diamonds), $20 \mathrm{~nm}$ (blue circles), and $10 \mathrm{~nm}$ (orange squares). Reproduced with permission [33]. Copyright 2016, American Chemical Society.

Experimentally, the electrical conductivity of hybrid perovskite material was improved by photo or chemical induced doping $[35,160]$.

The effect of light (photoelectron) and impurity doping on thermoelectric properties of $\mathrm{CH}_{3} \mathrm{NH}_{3} \mathrm{MI}_{3}\left(\mathrm{M}=\mathrm{Pb}\right.$, Sn) samples were investigated. The electrical conductivity of $\mathrm{CH}_{3} \mathrm{NH}_{3} \mathrm{PbI}_{3}$ 
increased from $10^{-7}$ to $10^{-5} \mathrm{~S} \cdot \mathrm{cm}^{-1}$ with a carrier concentration of about $10^{14} \mathrm{~cm}^{-3}$ from light doping, when changed from dark to light intensities of $220 \mathrm{~mW} \cdot \mathrm{cm}^{-2}$. The $\mathrm{S}$ at room temperature $\left(295 \mathrm{~K}\right.$ ) decreased upon illumination, from $\mathrm{S}_{\text {dark }}=820 \mu \mathrm{V} \cdot \mathrm{K}^{-1}$ to $\mathrm{S}_{\text {light }}=540 \mu \mathrm{V} \cdot \mathrm{K}^{-1}$. Additionally, the electrical conductivity of $10^{-3} \mathrm{~S} \cdot \mathrm{cm}^{-1}$ was achieved for $\mathrm{CH}_{3} \mathrm{NH}_{3} \mathrm{SnI}_{3}$ through impurity doping. The largest $\mathrm{ZT}$ values obtained was 0.008 at $295 \mathrm{~K}$ for $\mathrm{CH}_{3} \mathrm{NH}_{3} \mathrm{SnI}_{3}$ (Figure 14) [160]. Additionally, the TE properties of n-type organic/inorganic hybrid $\mathrm{C}_{6} \mathrm{H}_{4} \mathrm{NH}_{2} \mathrm{CuBr}_{2} \mathrm{I}$ were investigated. The materials achieved a carrier concentration of $8.7 \times 10^{20} \mathrm{~cm}^{-3}$. This high charge carrier concentration could be attributed to the self-doping effect caused by the reduction of $\mathrm{Cu}^{2+}$ in the $\mathrm{C}_{6} \mathrm{H}_{4} \mathrm{NH}_{2} \mathrm{CuBr}_{2} \mathrm{I}$ film. A part of the $\mathrm{Cu}^{2+}$ sites in the film could be replaced by $\mathrm{Cu}^{+}$, which can be reduced during the annealing process and affected by the presence of $\mathrm{Br}^{-}$. When a part of the $\mathrm{Cu}^{2+}$ sites was replaced by $\mathrm{Cu}^{+}$, the negatively charged $\mathrm{Cu}(+)^{\prime}{ }_{\mathrm{Cu}(2+)}$ defects would be formed in $\mathrm{C}_{6} \mathrm{H}_{4} \mathrm{NH}_{2} \mathrm{CuBr}_{2} \mathrm{I}$. Furthermore, the former composition becomes $\mathrm{C}_{6} \mathrm{H}_{4} \mathrm{NH}_{2} \mathrm{Cu}_{1-\mathrm{x}}{ }^{2+} \mathrm{Cu}_{\mathrm{x}}{ }^{+} \mathrm{X}_{3-\mathrm{x}}$ $\left(\mathrm{X}=\mathrm{I}^{-}\right.$or $\left.\mathrm{Br}^{-}\right)$, resulting in vacancies of $\mathrm{X}^{-}\left(\mathrm{V}^{\prime} \mathrm{X}\right)$. The formation of negatively charged defects, such as $\mathrm{Cu}(+)^{\prime}{ }_{\mathrm{Cu}(2+)}$ and $\mathrm{V}^{\prime}{ }_{\mathrm{X}}$, induce electron doping. The film has an electrical conductivity of $\sim 3.6 \times 10^{3} \mathrm{~S} \cdot \mathrm{cm}^{-1}$ and a Seebeck coefficient of $\sim-70 \mu \mathrm{V} \cdot \mathrm{K}^{-1}$ at room temperature, resulting in a power factor of $1740 \mu \mathrm{W} \cdot \mathrm{m}^{-1} \cdot \mathrm{K}^{-2}$. The details about the TE properties were shown in Figure 15. The highest estimated ZT value using calculated thermal conductivity was 0.21 at $363 \mathrm{~K}$ [35].

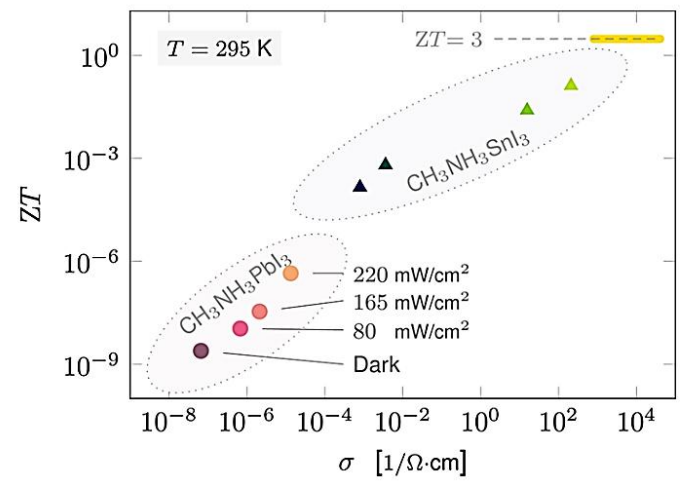

Figure 14. $\mathrm{ZT}$ of $\mathrm{CH}_{3} \mathrm{NH}_{3} \mathrm{PbI}_{3}$ and $\mathrm{CH}_{3} \mathrm{NH}_{3} \mathrm{SnI}_{3}$ at $295 \mathrm{~K}$, with doping, monitored through the conductivity increase with photo and impurity doping. Red, orange, and yellow correspond to light intensities of 80,165, and $220 \mathrm{~mW} \cdot \mathrm{cm}^{-2}$. The dashed line marks ZT $=3$. Adapted with permission [160]. Copyright 2015, American Chemical Society.
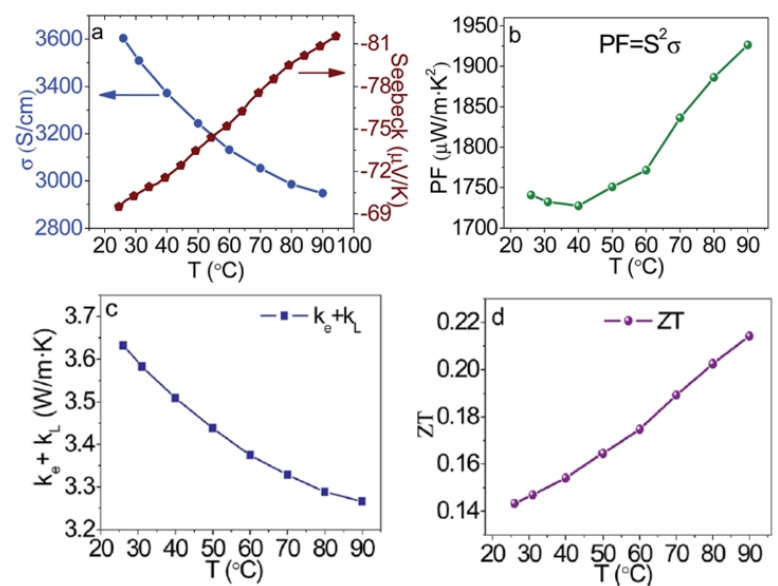

Figure 15. Electrical conductivity, Seebeck coefficient, power factor, calculated thermal conductivity, and $\mathrm{ZT}$ at different temperatures for the $\mathrm{C}_{6} \mathrm{H}_{4} \mathrm{NH}_{2} \mathrm{CuBr}_{2} \mathrm{I}$. Reproduced with permission [35]. Copyright 2017, Royal Society of Chemistry. 
In short, chemical doping is more effective than light doping strategy in hybrid perovskite materials [35,160]. The investigation of hybrid perovskite materials for TE application is just started, but it shows great potential with a power factor reaching $1740 \mu \mathrm{W} \cdot \mathrm{m}^{-1} \cdot \mathrm{K}^{-2}$ by self-doping strategies [35]. Hybrid perovskites can be promising TE materials with further modification by strategies, such as band-engineering, nano-engineering, doping/substitution, and self-doping (Figure 16).

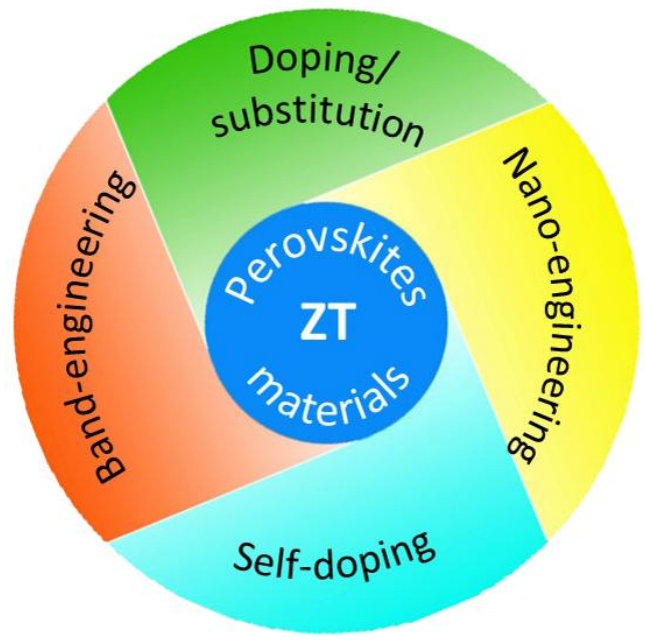

Figure 16. Possible strategies to enhance the thermoelectric ZT value of perovskite materials.

\section{Conclusions and Outlook}

The ZT values of the oxide and hybrid perovskite materials from reported experimental data were summarized in Figure 17. The ZT in Figure 17 was read from the literature at its optimum working temperature. Compared to the ZT value of the conventional thermoelectric materials (e.g., BiSbTe [163], $\mathrm{AgPb}_{18} \mathrm{SbTe}_{20}$ (LAST) [171], and SiGe [172]), the ZT values of perovskite materials still need to be further improved.

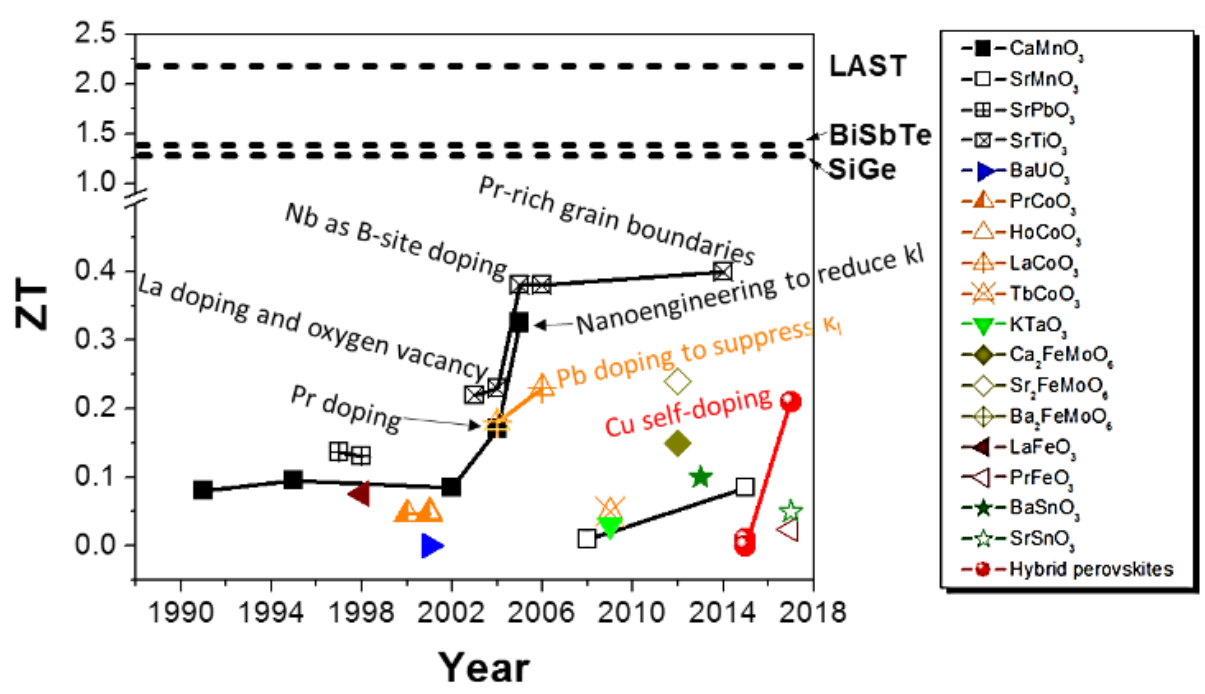

Figure 17. Summary of thermoelectric ZT values of oxide and hybrid perovskite materials by year. The three dashed lines are the ZT value of BiSbTe [163], $\mathrm{AgPb}_{18} \mathrm{SbTe}_{20}$ (LAST) [171], and SiGe [172], which have a different optimum working temperature. The thermoelectric ZT values of all materials were extracted from literature at its optimum working temperature. 
Oxide perovskites were applied as TE materials in a wide range of temperature (from $100 \mathrm{~K}-1400 \mathrm{~K})$. The highest ZT value of oxide perovskite materials obtained experimentally so far is $\sim 0.4$. The reason for the low ZT value is that oxide perovskite materials have low electrical conductivity and high thermal conductivity. Doping is usually used as a strategy to improve the TE properties, which would normally increase the carrier concentration of materials, thus enhancing the electrical conductivity. In general, A-site doping (e.g., La doping in $\mathrm{SrTiO}_{3}$ ) [40,60-67] is more effective than B-site doping $[65,68,69,76]$ in enhancing the electrical conductivity through increasing the carrier concentration, in some cases when lattice thermal conductivity is dominant, A-site doping can also reduce the thermal conductivity $[62,73]$. On the other hand, B-site doping $[83,107]$ and grain boundary [59] are typically more effective in introducing phonon scattering, thus suppressing the lattice thermal conductivity (e.g., Pb substitution of $\mathrm{La}$ in $\mathrm{LaCoO}_{3}$ ) $[83,94,95,102,107,126]$. Additionally, the B-site doping can improve the ISI because of increase the effective mass (e.g., $\mathrm{Nb}$ substitution of $\mathrm{Ti}$ in $\mathrm{SrTiO}_{3}$ ) [65,68]. Moreover, quantum confinement effect can also enhance ISI of perovskite materials dramatically [75]. Furthermore, a small amount of oxygen vacancy in the crystal can have a positive effect on electrical conductivity [38,57-59], enhance the Seebeck coefficient [62-64], or even suppress the thermal conductivity [79], but it needs to cooperate with other strategies (e.g., A-site or B-site doping) to have a dramatic effect on TE properties. Also, the Pr doping in STO can create Pr rich grain boundaries, which enhances the mobility of the charge carrier significantly [40].

Hybrid perovskite materials started to draw attention for TE application in recent years. It can be a promising TE because of high Seebeck coefficient $\left(700 \mu \mathrm{V} \cdot \mathrm{K}^{-1}\right.$ for $\mathrm{CH}_{3} \mathrm{NH}_{3} \mathrm{PbI}_{3}$ at $\left.295 \mathrm{~K}\right)$ [160] and low thermal conductivity $\left(0.5 \mathrm{~W} \mathrm{~m}^{-1} \cdot \mathrm{K}^{-1}\right.$ for $\mathrm{CH}_{3} \mathrm{NH}_{3} \mathrm{PbI}_{3}$ at $\left.295 \mathrm{~K}\right)$ [160]. To improve the electrical conductivity, photo-induced and/or chemical-induced doping was applied. Chemical doping has experimentally proven to be more effective than light doping strategy $[35,160]$. For instance, in the film of $\mathrm{C}_{6} \mathrm{H}_{4} \mathrm{NH}_{2} \mathrm{CuBr}_{2} \mathrm{I}$, a part of the $\mathrm{Cu}^{2+}$ sites could be replaced by $\mathrm{Cu}^{+}$, then the negatively charged $\mathrm{Cu}(+)^{\prime} \mathrm{Cu}(2+)$ defects would form in $\mathrm{C}_{6} \mathrm{H}_{4} \mathrm{NH}_{2} \mathrm{CuBr}_{2} \mathrm{I}$, resulting in a carrier concentration of $\sim 8.7 \times 10^{20} \mathrm{~cm}^{-3}$ [35]. The TE properties of hybrid perovskite materials were simulated at high temperature $(\mathrm{T}>600 \mathrm{~K})$ [33], but they can be decomposed at about $373 \mathrm{~K}$ based on their stability limitations [173]. According to the self-doping mechanism, $\mathrm{Pb}$ can be replaced by elements that have multiple valence states, which is a potential choice for self-doping elements in hybrid perovskites. Other strategies to improve TE properties of materials, such as band-engineering and nanoengineering, can be applied to hybrid perovskite materials (Figure 16). The theoretical calculation results claimed that hybrid perovskite materials could achieve a ZT value of 0.9 for n-type $[33,34,161,162]$ and 1.25 for p-type [161,162]. Hybrid perovskite materials, which have low capital cost and can be quickly processed by energy cost methods, can be a promising candidate for TE application near room temperature range. Hybrid perovskite materials have the potential for flexible/wearable thermoelectric generator/cooling devices.

Funding: P.G. acknowledges the financial support from "Hundred Talents Program" of the Haixi Institute Chinese Academy of Sciences (no. 1017001) and "Thousand Talents Program" of the Government of China.

Conflicts of Interest: There are no conflicts to declare.

\section{References}

1. Zebarjadi, M.; Esfarjani, K.; Dresselhaus, M.S.; Ren, Z.F.; Chen, G. Perspectives on thermoelectrics: From fundamentals to device applications. Energy Environ. Sci. 2012, 5, 5147-5162. [CrossRef]

2. Nolas, G.S.; Sharp, J.; Goldsmid, H.J. Thermoelectrics; Springer Series in MATERIALS SCIENCE; Springer: Berlin/Heidelberg, Germany, 2001; Volume 45, pp. 59-109, ISBN 978-3-642-07451-6.

3. Sootsman, J.R.; Chung, D.Y.; Kanatzidis, M.G. New and Old Concepts in Thermoelectric Materials. Angew. Chem. Int. Ed. 2009, 48, 8616-8639. [CrossRef] [PubMed]

4. Snyder, G.J.; Ursell, T.S. Thermoelectric Efficiency and Compatibility. Phys. Rev. Lett. 2003, 91, 148301. [CrossRef] [PubMed] 
5. McGrail, B.T.; Sehirlioglu, A.; Pentzer, E. Polymer composites for thermoelectric applications. Angew. Chem. Int. Ed. 2015, 54, 1710-1723. [CrossRef] [PubMed]

6. Russ, B.; Glaudell, A.; Urban, J.J.; Chabinyc, M.L.; Segalman, R.A. Organic thermoelectric materials for energy harvesting and temperature control. Nat. Rev. Mater. 2016, 1, 16050. [CrossRef]

7. Nielsch, K.; Bachmann, J.; Kimling, J.; Böttner, H. Thermoelectric Nanostructures: From Physical Model Systems towards Nanograined Composites. Adv. Energy Mater. 2011, 1, 713-731. [CrossRef]

8. He, J.; Kanatzidis, M.G.; Dravid, V.P. High performance bulk thermoelectrics via a panoscopic approach. Mater. Today 2013, 16, 166-176. [CrossRef]

9. Alam, H.; Ramakrishna, S. A review on the enhancement of figure of merit from bulk to nano-thermoelectric materials. Nano Energy 2013, 2, 190-212. [CrossRef]

10. Snyder, G.J.; Toberer, E.S. Complex thermoelectric materials. Nat. Mater. 2008, 7, 105-114. [CrossRef] [PubMed]

11. Lan, Y.; Minnich, A.J.; Chen, G.; Ren, Z. Enhancement of Thermoelectric Figure-of-Merit by a Bulk Nanostructuring Approach. Adv. Funct. Mater. 2010, 20, 357-376. [CrossRef]

12. Kanatzidis, M.G. Nanostructured Thermoelectrics: The New Paradigm? Chem. Mater. 2010, 22, 648-659. [CrossRef]

13. Zhang, Y.; Snedaker, M.L.; Birkel, C.S.; Mubeen, S.; Ji, X.; Shi, Y.; Liu, D.; Liu, X.; Moskovits, M.; Stucky, G.D. Silver-Based Intermetallic Heterostructures in $\mathrm{Sb}_{2} \mathrm{Te}_{3}$ Thick Films with Enhanced Thermoelectric Power Factors. Nano Lett. 2012, 12, 1075-1080. [CrossRef] [PubMed]

14. Meng, B.C.; Liu, C.; Fan, S. A Promising Approach to Enhanced Thermoelectric Properties Using Carbon Nanotube Networks. Adv. Mater. 2010, 22, 535-539. [CrossRef] [PubMed]

15. He, M.; Ge, J.; Lin, Z.; Feng, X.; Wang, X.; Lu, H.; Yanga, Y.; Qiu, F. Environmental Science energy scattering at the organic-Inorganic semiconductor interface. Energy Environ. Sci. 2012, 5, 8351-8358. [CrossRef]

16. Faleev, S.V.; Leonard, F. Theory of enhancement of thermoelectric properties of materials with nanoinclusions. Phys. Rev. B 2008, 77, 214304. [CrossRef]

17. Yang, J.; Yip, H.-L.; Jen, A.K.-Y. Rational Design of Advanced Thermoelectric Materials. Adv. Energy Mater. 2013, 3, 549-565. [CrossRef]

18. LaLonde, A.D.; Pei, Y.; Wang, H.; Jeffrey Snyder, G. Lead telluride alloy thermoelectrics. Mater. Today 2011, 14, 526-532. [CrossRef]

19. Wu, T.; Zhang, M.; Lee, K.-H.; Lee, C.-M.; Lee, H.-K.; Choa, Y.; Myung, N.V. Electrodeposition of Compact Tellurium Thick Films from Alkaline Baths. J. Electrochem. Soc. 2017, 164, D82-D87. [CrossRef]

20. Wu, T.; Lee, H.-K.; Myung, N.V. Electrodeposition of Dense Lead Telluride Thick Films in Alkaline Solutions. J. Electrochem. Soc. 2016, 163, D801-D808. [CrossRef]

21. Snyder, G.J.; Lim, J.R.; Huang, C.-K.; Fleurial, J.-P. Thermoelectric microdevice fabricated by a MEMS-like electrochemical process. Nat. Mater. 2003, 2, 528-531. [CrossRef] [PubMed]

22. Rostek, R.; Stein, N.; Boulanger, C. A review of electroplating for V-VI thermoelectric films: From synthesis to device integration. J. Mater. Res. 2015, 30, 2518-2543. [CrossRef]

23. Massaro, M.; Dumay, J.; Bagnoli, C. Where there is a will there is a way. J. Intellect. Cap. 2015, 16, 490-517. [CrossRef]

24. Bubnova, O.; Khan, Z.U.; Malti, A.; Braun, S.; Fahlman, M.; Berggren, M.; Crispin, X. Optimization of the thermoelectric figure of merit in the conducting polymer poly(3,4-ethylenedioxythiophene). Nat. Mater. 2011, 10, 429-433. [CrossRef] [PubMed]

25. He, M.; Qiu, F.; Lin, Z. Towards high-performance polymer-based thermoelectric materials. Energy Environ. Sci. 2013, 6, 1352-1361. [CrossRef]

26. Shi, W.; Chen, J.; Xi, J.; Wang, D.; Shuai, Z. Search for Organic Thermoelectric Materials with High Mobility: The Case of 2,7-Dialkyl[1]benzothieno[3,2-b][1]benzothiophene Derivatives. Chem. Mater. 2014, 26, 2669-2677. [CrossRef]

27. Zhang, Q.; Sun, Y.; Xu, W.; Zhu, D. Organic Thermoelectric Materials: Emerging Green Energy Materials Converting Heat to Electricity Directly and Efficiently. Adv. Mater. 2014, 26, 6829-6851. [CrossRef] [PubMed]

28. Taroni, P.J.; Hoces, I.; Stingelin, N.; Heeney, M.; Bilotti, E. Thermoelectric materials: A brief historical survey from metal junctions and inorganic semiconductors to organic polymers. Isr. J. Chem. 2014, 54, 534-552. [CrossRef] 
29. Shi, K.; Zhang, F.; Di, C.-A.A.; Yan, T.-W.W.; Zou, Y.; Zhou, X.; Zhu, D.; Wang, J.-Y.Y.; Pei, J. Toward High Performance $\mathrm{n}$-Type Thermoelectric Materials by Rational Modification of BDPPV Backbones. J. Am. Chem. Soc. 2015, 137, 6979-6982. [CrossRef] [PubMed]

30. Kroon, R.; Mengistie, D.A.; Kiefer, D.; Hynynen, J.; Ryan, J.D.; Yu, L.; Müller, C. Thermoelectric plastics: From design to synthesis, processing and structure-property relationships. Chem. Soc. Rev. 2016, 45, 6147-6164. [CrossRef] [PubMed]

31. Chen, G.; Xu, W.; Zhu, D. Recent advances in organic polymer thermoelectric composites. J. Mater. Chem. C 2017, 5, 4350-4360. [CrossRef]

32. Cowen, L.M.; Atoyo, J.; Carnie, M.J.; Baran, D.; Schroeder, B.C. Review-Organic Materials for Thermoelectric Energy Generation. ECS J. Solid State Sci. Technol. 2017, 6, N3080-N3088. [CrossRef]

33. Filippetti, A.; Caddeo, C.; Delugas, P.; Mattoni, A. Appealing Perspectives of Hybrid Lead-Iodide Perovskites as Thermoelectric Materials. J. Phys. Chem. C 2016, 120, 28472-28479. [CrossRef]

34. Lee, C.; Hong, J.; Stroppa, A.; Whangbo, M.-H.; Shim, J.H. Organic-inorganic hybrid perovskites $\mathrm{ABI}_{3}$ $\left(\mathrm{A}=\mathrm{CH}_{3} \mathrm{NH}_{3}, \mathrm{NH}_{2} \mathrm{CHNH}_{2} ; \mathrm{B}=\mathrm{Sn}, \mathrm{Pb}\right)$ as potential thermoelectric materials: A density functional evaluation. RSC Adv. 2015, 5, 78701-78707. [CrossRef]

35. Liu, Y.; Li, X.; Wang, J.; Xu, L.; Hu, B. An extremely high power factor in Seebeck effects based on a new n-type copper-based organic/inorganic hybrid $\mathrm{C}_{6} \mathrm{H}_{4} \mathrm{NH}_{2} \mathrm{CuBr}_{2} \mathrm{I}$ film with metal-like conductivity. J. Mater. Chem. A 2017, 5, 13834-13841. [CrossRef]

36. Wood, C. Materials for thermoelectric energy conversion. Inst. Phys. 1988, 51, 459-539. [CrossRef]

37. Szczech, J.R.; Higgins, J.M.; Jin, S. Enhancement of the thermoelectric properties in nanoscale and nanostructured materials. J. Mater. Chem. 2011, 21, 4037-4055. [CrossRef]

38. Choi, W.S.; Yoo, H.K.; Ohta, H. Polaron transport and thermoelectric behavior in la-doped $\mathrm{SrTio}_{3}$. thin films with elemental vacancies. Adv. Funct. Mater. 2015, 25, 799-804. [CrossRef]

39. Roy, P.; Waghmare, V.; Maiti, T. Environmentally friendly $\mathrm{Ba}_{\mathrm{x}} \mathrm{Sr}_{2-\mathrm{x}} \mathrm{TiFeO}_{6}$ double perovskite with enhanced thermopower for high temperature thermoelectric power generation. RSC Adv. 2016, 6, 54636-54643. [CrossRef]

40. Mehdizadeh Dehkordi, A.; Bhattacharya, S.; Darroudi, T.; Graff, J.W.; Schwingenschlögl, U.; Alshareef, H.N.; Tritt, T.M. Large thermoelectric power factor in Pr-doped $\mathrm{SrTiO}_{3-\delta}$ ceramics via grain-boundary-induced mobility enhancement. Chem. Mater. 2014, 26, 2478-2485. [CrossRef]

41. Zhang, M.; Park, H.; Kim, J.; Park, H.; Wu, T.; Kim, S.; Park, S.-D.; Choa, Y.; Myung, N.V. Thermoelectric Properties of Ultralong Silver Telluride Hollow Nanofibers. Chem. Mater. 2015, 27, 5189-5197. [CrossRef]

42. Wu, T.; Zhang, M.; Lee, K.-H.; Kim, S.; Choa, Y.; Myung, N.V. Synthesis of Tellurium Heterostructures by Galvanic Displacement Reaction of Zinc in Alkaline Baths. Electrochim. Acta 2014, 150, 298-307. [CrossRef]

43. Wu, T.; Myung, L.Y.; Zhang, M.; Lee, K.-H.; Lee, Y.L.; Lim, H.-R.; Kim, B.S.; Choa, Y.-H.; Myung, N.V. Size Controlled Synthesis of Tellurium Nanorices by Galvanic Displacement Reaction of Aluminum. Electrochim. Acta 2015, 176, 1382-1392. [CrossRef]

44. Sahu, A.; Russ, B.; Su, N.C.; Forster, J.D.; Zhou, P.; Cho, E.S.; Ercius, P.; Coates, N.E.; Segalman, R.A.; Urban, J.J. Bottom-up design of de novo thermoelectric hybrid materials using chalcogenide resurfacing. J. Mater. Chem. A 2017, 5, 3346-3357. [CrossRef]

45. Du, Y.; Shen, S.Z.; Cai, K.; Casey, P.S. Research progress on polymer-inorganic thermoelectric nanocomposite materials. Prog. Polym. Sci. 2012, 37, 820-841. [CrossRef]

46. Chen, Y.; Zhao, Y.; Liang, Z. Solution processed organic thermoelectrics: Towards flexible thermoelectric modules. Energy Environ. Sci. 2015, 8, 401-422. [CrossRef]

47. De Trizio, L.; Manna, L. Forging Colloidal Nanostructures via Cation Exchange Reactions. Chem. Rev. 2016, 116, 10852-10887. [CrossRef] [PubMed]

48. Moon, G.D.; Ko, S.; Min, Y.; Zeng, J.; Xia, Y.; Jeong, U. Chemical transformations of nanostructured materials. Nano Today 2011, 6, 186-203. [CrossRef]

49. Terasaki, I.; Sasago, Y.; Uchinokura, K. Large thermoelectric power in $\mathrm{NaCo}_{2} \mathrm{O}_{4}$ single crystals. Phys. Rev. B 1997, 56, R12685-R12687. [CrossRef]

50. Funahashi, R.; Matsubara, I.; Sodeoka, S. Thermoelectric properties of $\mathrm{Bi}_{2} \mathrm{Sr}_{2} \mathrm{Co}_{2} \mathrm{O}_{\mathbf{x}}$ polycrystalline materials. Appl. Phys. Lett. 2000, 76, 2385-2387. [CrossRef] 
51. Masset, A.C.; Michel, C.; Maignan, A.; Hervieu, M.; Toulemonde, O.; Studer, F.; Raveau, B.; Hejtmanek, J. Misfit-layered cobaltite with an anisotropic giant magnetoresistance: $\mathrm{Ca}_{3} \mathrm{Co}_{4} \mathrm{O}_{9}$. Phys. Rev. B 2000, 62, 166-175. [CrossRef]

52. Ohtaki, M.; Araki, K.; Yamamoto, K. High thermoelectric performance of dually doped ZnO ceramics. J. Electron. Mater. 2009, 38, 1234-1238. [CrossRef]

53. Gao, P.; Grätzel, M.; Nazeeruddin, M.K. Organohalide lead perovskites for photovoltaic applications. Energy Environ. Sci. 2014, 7, 2448-2463. [CrossRef]

54. Yin, W.-J.; Yang, J.-H.; Kang, J.; Yan, Y.; Wei, S.-H. Halide perovskite materials for solar cells: A theoretical review. J. Mater. Chem. A 2015, 3, 8926-8942. [CrossRef]

55. Kagan, C.R. Organic-Inorganic Hybrid Materials as Semiconducting Channels in Thin-Film Field-Effect Transistors. Science 1999, 286, 945-947. [CrossRef] [PubMed]

56. Wang, M.; Lin, S. Anisotropic and Ultralow Phonon Thermal Transport in Organic-Inorganic Hybrid Perovskites: Atomistic Insights into Solar Cell Thermal Management and Thermoelectric Energy Conversion Efficiency. Adv. Funct. Mater. 2016, 26, 5297-5306. [CrossRef]

57. Ravichandran, J.; Siemons, W.; Oh, D.W.; Kardel, J.T.; Chari, A.; Heijmerikx, H.; Scullin, M.L.; Majumdar, A.; Ramesh, R.; Cahill, D.G. High-temperature thermoelectric response of double-doped $\mathrm{SrTiO}_{3}$ epitaxial films. Phys. Rev. B 2010, 82, 165126. [CrossRef]

58. Onoda, M.; Tsukahara, S. The upper limit of thermoelectric power factors in the metal-band-insulator crossover of the perovskite-type oxygen deficient system $\mathrm{SrTiO}_{3-\delta / 2}$. J. Phys. Condens. Matter 2011, 23, 45604. [CrossRef] [PubMed]

59. Feng, X.; Fan, Y.; Nomura, N.; Kikuchi, K.; Wang, L.; Jiang, W.; Kawasaki, A. Graphene promoted oxygen vacancies in perovskite for enhanced thermoelectric properties. Carbon 2017, 112, 169-176. [CrossRef]

60. Jalan, B.; Stemmer, S. Large Seebeck coefficients and thermoelectric power factor of La-doped $\mathrm{SrTiO}_{3}$ thin films. Appl. Phys. Lett. 2010, 97, 2008-2011. [CrossRef]

61. Moos, R.; Gnudi, A.; Härdtl, K.H. Thermopower of $\mathrm{Sr}_{1-\mathrm{x}} \mathrm{La}_{\mathrm{x}} \mathrm{TiO}_{3}$ ceramics. J. Appl. Phys. 1995, 78, $5042-5047$. [CrossRef]

62. Muta, H.; Kurosaki, K.; Yamanaka, S. Thermoelectric properties of rare earth doped $\mathrm{SrTiO}_{3}$. J. Alloys Compd. 2003, 350, 292-295. [CrossRef]

63. Muta, H.; Kurosaki, K.; Yamanaka, S. Thermoelectric properties of reduced and La-doped single-crystalline $\mathrm{SrTiO}_{3}$. J. Alloys Compd. 2005, 392, 306-309. [CrossRef]

64. Liu, J.; Wang, C.L.; Su, W.B.; Wang, H.C.; Zheng, P.; Li, J.C.; Zhang, J.L.; Mei, L.M. Enhancement of thermoelectric efficiency in oxygen-deficient $\mathrm{Sr}_{1-\mathrm{x}} \mathrm{La}_{x} \mathrm{TiO}_{3-\delta}$ ceramics. Appl. Phys. Lett. 2009, 95, 162110. [CrossRef]

65. Ohta, S.; Nomura, T.; Ohta, H.; Koumoto, K. High-temperature carrier transport and thermoelectric properties of heavily La- Or Nb-doped $\mathrm{SrTiO}_{3}$ single crystals. J. Appl. Phys. 2005, 97, 034106. [CrossRef]

66. Onoda, M.; Goto, I. Correlation and phonon effects for the electronic transport and thermoelectric power factors in the metal-band-insulator crossover of perovskite-type titanates. J. Phys. Condens. Matter 2009, 21, 435603. [CrossRef] [PubMed]

67. Sugahara, T.; Ohtaki, M. Structural and semiconductor-to-metal transitions of double-perovskite cobalt oxide $\mathrm{Sr}_{2-x} \mathrm{La}_{x} \mathrm{CoTiO}_{6-\delta}$ with enhanced thermoelectric capability. Appl. Phys. Lett. 2011, 99, 62107. [CrossRef]

68. Ohta, S.; Nomura, T.; Ohta, H.; Hirano, M.; Hosono, H.; Koumoto, K. Large thermoelectric performance of heavily $\mathrm{Nb}$-doped $\mathrm{SrTiO}_{3}$ epitaxial film at high temperature. Appl. Phys. Lett. 2005, 87, 092108. [CrossRef]

69. Nasir Khan, M.; Kim, H.T.; Minami, H.; Uwe, H. Thermoelectric properties of niobium doped hexagonal barium titanate. Mater. Lett. 2001, 47, 95-101. [CrossRef]

70. Kolodiazhnyi, T.; Petric, A.; Niewczas, M.; Bridges, C.; Safa-Sefat, A.; Greedan, J.E. Thermoelectric power, Hall effect, and mobility of n-type $\mathrm{BaTiO}_{3}$. Phys. Rev. B 2003, 68, 85205. [CrossRef]

71. Obara, H.; Yamamoto, A.; Lee, C.H.; Kobayashi, K.; Matsumoto, A.; Funahashi, R. Thermoelectric properties of Y-doped polycrystalline $\mathrm{SrTiO}_{3}$. Jpn. J. Appl. Phys. 2004, 43, L540. [CrossRef]

72. Muta, H.; Kurosaki, K.; Yamanaka, S. Thermoelectric properties of doped $\mathrm{BaTiO}_{3}-\mathrm{SrTiO}_{3}$ solid solution. J. Alloys Compd. 2004, 368, 22-24. [CrossRef]

73. Muta, H.; Ieda, A.; Kurosaki, K.; Yamanaka, S. Substitution effect on the thermoelectric properties of alkaline earth titanate. Mater. Lett. 2004, 58, 3868-3871. [CrossRef] 
74. Okuda, T.; Nakanishi, K.; Miyasaka, S.; Tokura, Y. Large thermoelectric response of metallic perovskites: $\mathrm{Sr}_{1-\mathrm{x}} \mathrm{La}_{\mathbf{x}} \mathrm{TiO}_{3}(0<x<0.1)$. Phys. Rev. B 2001, 63, 113104. [CrossRef]

75. Ohta, H.; Kim, S.; Mune, Y.; Mizoguchi, T.; Nomura, K.; Ohta, S.; Nomura, T.; Nakanishi, Y.; Ikuhara, Y.; Hirano, M.; et al. Giant thermoelectric Seebeck coefficient of a two-dimensional electron gas in $\mathrm{SrTiO}_{3}$. Nat. Mater. 2007, 6, 129-134. [CrossRef] [PubMed]

76. Ohta, S.; Ohta, H.; Koumoto, K. Grain Size Dependence of Thermoelectric Performance of Nb-Doped SrTiO 3 Polycrystals. J. Ceram. Soc. Jpn. 2006, 114, 102-105. [CrossRef]

77. Kato, K.; Yamamoto, M.; Ohta, S.; Muta, H.; Kurosaki, K.; Yamanaka, S.; Iwasaki, H.; Ohta, H.; Koumoto, K. The effect of Eu substitution on thermoelectric properties of $\mathrm{SrTi}_{0.8} \mathrm{Nb}_{0.2} \mathrm{O}_{3}$. J. Appl. Phys. 2007, 102, 116107. [CrossRef]

78. Cui, Y.; Salvador, J.R.; Yang, J.; Wang, H.; Amow, G.; Kleinke, H. Thermoelectric properties of heavily doped n-type $\mathrm{SrTiO}_{3}$ bulk materials. J. Electron. Mater. 2009, 38, 1002-1007. [CrossRef]

79. Lee, S.; Yang, G.; Wilke, R.H.T.; Trolier-Mckinstry, S.; Randall, C.A. Thermopower in highly reduced n-type ferroelectric and related perovskite oxides and the role of heterogeneous nonstoichiometry. Phys. Rev. B 2009, 79, 134110. [CrossRef]

80. Usui, H.; Shibata, S.; Kuroki, K. Origin of coexisting large Seebeck coefficient and metallic conductivity in the electron doped $\mathrm{SrTiO}_{3}$ and $\mathrm{KTaO}_{3}$. Phys. Rev. B 2010, 81, 205121. [CrossRef]

81. Filippetti, A.; Delugas, P.; Verstraete, M.J.; Pallecchi, I.; Gadaleta, A.; Marré, D.; Li, D.F.; Gariglio, S.; Fiorentini, V. Thermopower in oxide heterostructures: The importance of being multiple-band conductors. Phys. Rev. B 2012, 86, 195301. [CrossRef]

82. Delugas, P.; Filippetti, A.; Verstraete, M.J.; Pallecchi, I.; Marré, D.; Fiorentini, V. Doping-induced dimensional crossover and thermopower burst in $\mathrm{Nb}$-doped $\mathrm{SrTiO}_{3}$ superlattices. Phys. Rev. B 2013, 88, 045310. [CrossRef]

83. Okuda, T.; Hata, H.; Eto, T.; Nishina, K.; Kuwahara, H.; Nakamura, M.; Kajimoto, R. Effects of Mn substitution on the thermoelectric properties of the electron-doped perovskite $\mathrm{Sr}_{1-x} \mathrm{La}_{x} \mathrm{TiO}_{3}$. J. Phys. Conf. Ser. 2014, 568, 22035. [CrossRef]

84. Choi, W.S.; Ohta, H.; Lee, H.N. Thermopower enhancement by fractional layer control in 2D oxide superlattices. Adv. Mater. 2014, 26, 6701-6705. [CrossRef] [PubMed]

85. Sun, J.; Singh, D.J. Thermoelectric properties of $n$-type $\mathrm{SrTiO}_{3}$. APL Mater. 2016, 4, 104803. [CrossRef]

86. Roy, P.; Bose, I.; Maiti, T. Synthesis and characterization of $\mathrm{Sr}_{2} \mathrm{TiMO}_{6}(\mathrm{M}=\mathrm{Fe}, \mathrm{Co})$ double perovskites for high temperature thermoelectric applications. Integr. Ferroelectr. 2016, 174, 34-42. [CrossRef]

87. Saxena, M.; Tanwar, K.; Maiti, T. Environmental friendly $\mathrm{Sr}_{2} \mathrm{TiMoO}_{6}$ double perovskite for high temperature thermoelectric applications. Scr. Mater. 2017, 130, 205-209. [CrossRef]

88. Ohkubo, I.; Mori, T. Comparative Study of Exchange-Correlation Functional and Potential for Evaluating Thermoelectric Transport Properties in d 0 Perovskite Oxides. J. Phys. Soc. Jpn. 2017, 86, 74705. [CrossRef]

89. Kahaly, M.U.; Ozdogan, K.; Schwingenschlögl, U. Half-metallic perovskite superlattices with colossal thermoelectric figure of merit. J. Mater. Chem. A 2013, 1, 8406-8410. [CrossRef]

90. Kobayashi, T.; Takizawa, H.; Endo, T.; Sato, T.; Shimada, M.; Taguchi, H.; Nagao, M. Metal-insulator transition and thermoelectric properties in the system $\left(R_{1-\mathrm{x}} \mathrm{Ca}_{\mathrm{x}}\right) \mathrm{MnO}_{3-\delta}(R: \mathrm{Tb}, \mathrm{Ho}, \mathrm{Y})$. J. Solid State Chem. 1991, 92, 116-129. [CrossRef]

91. Ohtaki, M.; Koga, H.; Tokunaga, T.; Eguchi, K.; Arai, H. Electrical Transport Properties and High-Temperature Thermoelectric Performance of $\left(\mathrm{Ca}_{0.9} M_{0.1}\right) \mathrm{MnO}_{3}(M=\mathrm{Y}, \mathrm{La}, \mathrm{Ce}, \mathrm{Sm}, \mathrm{In}, \mathrm{Sn}, \mathrm{Sb}, \mathrm{Pb}, \mathrm{Bi})$. J. Solid State Chem. 1995, 120, 105-111. [CrossRef]

92. Hashimoto, S.; Iwahara, H. Study on the structural and electrical properties of $\mathrm{Sr}_{1-\mathrm{x}} \mathrm{Ce}_{\mathrm{x}} \mathrm{MnO}_{3-\mathrm{a}}(x=0.1$, 0.3) perovskite oxide. Mater. Res. Bull. 2000, 35, 2253-2262. [CrossRef]

93. Vecherskii, S.I.; Konopel'ko, M.A.; Esina, N.O.; Batalov, N.N. Transport Properties of $\mathrm{Ca}_{1-\mathrm{x}} \mathrm{MnO}_{3-\mathrm{d}}+\mathrm{xCeO}$ $(0<x \leq 0.15)$ Mixtures. Inorg. Mater. 2002, 38, 1270-1276.

94. Cong, B.T.; Tsuji, T.; Thao, P.X.; Thanh, P.Q.; Yamamura, Y. High-temperature thermoelectric properties of $\mathrm{Ca}_{1-x} \operatorname{Pr}_{x} \mathrm{MnO}_{3-\delta}(0 \leq x<1)$. Phys. B Condens. Matter 2004, 352, 18-23. [CrossRef]

95. Flahaut, D.; Mihara, T.; Funahashi, R.; Nabeshima, N.; Lee, K.; Ohta, H.; Koumoto, K. Thermoelectrical properties of A-site substituted $\mathrm{Ca}_{1-\mathrm{x}} \mathrm{Re}_{\mathrm{x}} \mathrm{MnO}_{3}$ system. J. Appl. Phys. 2006, 100, 84911. [CrossRef]

96. Park, K.; Lee, G.W.; Jung, J.; Kim, S.-J.; Lim, Y.-S.; Choi, S.-M.; Seo, W.-S. Thermoelectric Properties of $\mathrm{Ca}_{1-\mathrm{x}-\mathrm{y}} \mathrm{Dy}_{\mathrm{x}} \mathrm{Ce}_{\mathrm{y}} \mathrm{MnO}_{3}$ for Power Generation. J. Nanosci. Nanotechnol. 2011, 11, 7176-7179. [CrossRef] [PubMed] 
97. Nakatsugawa, H.; Kubota, M.; Saito, M. Thermoelectric and magnetic properties of $\operatorname{Pr}_{1-\mathrm{x}} \mathrm{Sr}_{\mathrm{x}} \mathrm{MnO}_{3}(0.1<x<0.7)$. Mater. Trans. 2015, 56, 864-871.

98. Hejtmánek, J.; Jirák, Z.; Maryško, M.; Martin, C.; Maignan, a.; Hervieu, M.; Raveau, B. Interplay between transport, magnetic, and ordering phenomena in $\mathrm{Sm}_{1-\mathrm{x}} \mathrm{Ca}_{\mathrm{x}} \mathrm{MnO}_{3}$. Phys. Rev. B 1999, 60, 14057-14065. [CrossRef]

99. Martin, C.; Maignan, A.; Hervieu, M.; Raveau, B.; Hejtmanek, J. Electron doping in $\mathrm{CaMnO}_{3}$ induced by Mo for Mn substitution: An efficient route to orbital and charge ordering. Phys. Rev. B 2001, 63, 100406. [CrossRef]

100. Gutierrez, D.; Peña, O.; Duran, P.; Moure, C. Crystal structure, electrical conductivity and Seebeck coefficient of $\mathrm{Y}(\mathrm{Mn}, \mathrm{Ni}) \mathrm{O}_{3}$ solid solution. J. Eur. Ceram. Soc. 2002, 22, 567-572. [CrossRef]

101. Maignan, A.; Hébert, S.; Pi, L.; Pelloquin, D.; Martin, C.; Michel, C.; Hervieu, M.; Raveau, B. Perovskite manganites and layered cobaltites: Potential materials for thermoelectric applications. Cryst. Eng. 2002, 5, 365-382. [CrossRef]

102. Maignan, A.; Martin, C.; Autret, C.; Hervieu, M.; Raveau, B.; Hejtmanek, J. Structural-magnetic phase diagram of Mo-substituted $\mathrm{CaMnO}_{3}$ : Consequences for thermoelectric power properties. J. Mater. Chem. 2002, 12, 1806-1811. [CrossRef]

103. Xu, G.; Funahashi, R.; Matsubara, I.; Shikano, M.; Zhou, Y. High-temperature Thermoelectric Properties of the $\mathrm{Ca}_{1-\mathrm{x}} \mathrm{Bi}_{\mathrm{x}} \mathrm{MnO}_{3}$ System. J. Mater. Res. 2002, 17, 1092-1095. [CrossRef]

104. Pi, L.; Hébert, S.; Martin, C.; Maignan, A.; Raveau, B. Comparison of $\mathrm{CaMn}_{1-\mathrm{x}} \mathrm{Ru}_{\mathrm{x}} \mathrm{O}_{3}$ and $\mathrm{CaMn}_{1-\mathrm{y}} \mathrm{Mo}_{\mathrm{y}} \mathrm{O}_{3}$ perovskites. Phys. Rev. B 2003, 67, 244301-244307. [CrossRef]

105. Xu, G.; Funahashi, R.; Pu, Q.; Liu, B.; Tao, R.; Wang, G.; Ding, Z. High-temperature transport properties of $\mathrm{Nb}$ and Ta substituted $\mathrm{CaMnO}_{3}$ system. Solid State Ion. 2004, 171, 147-151. [CrossRef]

106. Miclau, M.; Hébert, S.; Retoux, R.; Martin, C. Influence of A-site cation size on structural and physical properties in $\mathrm{Ca}_{1-\mathrm{x}} \mathrm{Sr}_{\mathrm{x}} \mathrm{Mn}_{0.96} \mathrm{Mo}_{0.04} \mathrm{O}_{3}$ : A comparison of the and 0.6 compounds. J. Solid State Chem. 2005, 178, 1104-1111. [CrossRef]

107. Bocher, L.; Aguirre, M.H.; Logvinovich, D.; Shkabko, A.; Robert, R.; Trottmann, M.; Weidenkaff, A. $\mathrm{CaMn}_{1-\mathrm{x}} \mathrm{Nb}_{\mathrm{x}} \mathrm{O}_{3}(x \leq 0.08)$ Perovskite-Type Phases As Promising New High-Temperature $n$-Type Thermoelectric Materials. Inorg. Chem. 2008, 47, 8077-8085. [CrossRef] [PubMed]

108. Kolesnik, S.; Dabrowski, B.; Chmaissem, O. Structural and physical properties of $\mathrm{SrMn}_{1-\mathrm{x}} \mathrm{Ru}_{\mathrm{x}} \mathrm{O}_{3}$ perovskites. Phys. Rev. B 2008, 78, 214425. [CrossRef]

109. Choi, S.-M.; Lim, C.-H.; Seo, W.-S. Thermoelectric Properties of the $\mathrm{Ca}_{1-\mathrm{x}} R_{\mathrm{x}} \mathrm{MnO}_{3}$ Perovskite System ( $R:$ Pr, Nd, Sm) for High-Temperature Applications. J. Electron. Mater. 2011, 40, 551-556. [CrossRef]

110. Suzuki, T.; Sakai, H.; Taguchi, Y.; Tokura, Y. Thermoelectric properties of electron-doped $\mathrm{SrMnO}_{3}$ single crystals with perovskite structure. J. Electron. Mater. 2012, 41, 1559-1563. [CrossRef]

111. Kawakami, H.; Saito, M.; Takemoto, H.; Yamamura, H.; Isoda, Y.; Shinohara, Y. Thermoelectric Properties of Perovskite-type Oxide Ca-Mn-O System in Relation to A-site Vacancies. Mater. Trans. 2013, 54, 1818-1822. [CrossRef]

112. Kim, C.M.; Seo, J.W.; Choi, S.-M.; Seo, W.-S.; Lee, S.; Lim, Y.S.; Park, K. Structural and thermoelectric properties of $n$-type $\mathrm{Sr}_{1-\mathrm{x}} \mathrm{Ti}_{\mathrm{x}} \mathrm{MnO}_{3-\delta}$ perovskite system. Electron. Mater. Lett. 2015, 11, 276-281. [CrossRef]

113. Moon, J.-W.; Seo, W.-S.; Okabe, H.; Okawa, T.; Koumoto, K. Ca-doped $\mathrm{RCoO}_{3}(R=\mathrm{Gd}, \mathrm{Sm}, \mathrm{Nd}, \mathrm{Pr})$ as thermoelectric materials. J. Mater. Chem. 2000, 10, 2007-2009. [CrossRef]

114. Moon, J.W.; Masuda, Y.; Seo, W.S.; Koumoto, K. Influence of ionic size of rare-earth site on the thermoelectric properties of $\mathrm{RCoO}_{3}$-type perovskite cobalt oxides. Mater. Sci. Eng. 2001, 85, 70-75. [CrossRef]

115. Hashimoto, H.; Kusunose, T.; Sekino, T. Influence of ionic sizes of rare earths on thermoelectric properties of perovskite-type rare earth cobalt oxides $\mathrm{RCoO}_{3}(R=\mathrm{Pr}, \mathrm{Nd}, \mathrm{Tb}, \mathrm{Dy})$. J. Alloys Compd. 2009, 484, $246-248$. [CrossRef]

116. Rao, C.N.R.; Bhide, V.G.; Mott, N.F. Hopping conduction in $\mathrm{La}_{1-\mathrm{x}} \mathrm{Sr}_{\mathrm{x}} \mathrm{CoO}_{3}$ and $\mathrm{Nd}_{1-\mathrm{x}} \mathrm{Sr}_{\mathrm{x}} \mathrm{CoO}_{3}$. Philos. Mag. 1975, 32, 1277-1282. [CrossRef]

117. Rao, C.N.R.; Parkash, O. Anderson transitions in $\mathrm{Ln}_{1-x} \mathrm{Sr}_{\mathrm{x}} \mathrm{CoO}_{3}(\mathrm{Ln}=\mathrm{Pr}$ or Nd). Philos. Mag. 1977, 35, $37-41$. [CrossRef]

118. Señarís-Rodríguez, M.A.; Goodenough, J.B. $\mathrm{LaCoO}_{3}$ Revisited. J. Solid State Chem. 1995, 116, $224-231$. [CrossRef] 
119. Señarís-Rodríguez, M.A.; Goodenough, J.B. Magnetic and Transport Properties of the System $\mathrm{La}_{1-\mathrm{x}} \mathrm{Sr}_{\mathrm{x}} \mathrm{CoO}_{3-\delta}(0<x \leq 0.50)$. J. Solid State Chem. 1995, 118, 323-336.

120. Kobayashi, Y.; Murata, S.; Asai, K.; Tranquada, J.M.; Shirane, G.; Kohn, K. Magnetic and transport properties of $\mathrm{LaCO}_{1-x} \mathrm{Ni}_{x} \mathrm{O}_{3}$-comparison with $\mathrm{La}_{1-x} \mathrm{Sr}_{x} \mathrm{CoO}_{3}$. J. Phys. Soc. Jpn. 1999, 68, 1011-1017. [CrossRef]

121. Moon, J.-W.; Masuda, Y.; Seo, W.-S.; Koumoto, K. Ca-doped $\mathrm{HoCoO}_{3}$ as p-type oxide thermoelectric material. Mater. Lett. 2001, 48, 225-229. [CrossRef]

122. Berggold, K.; Kriener, M.; Zobel, C.; Reichl, A.; Reuther, M.; Müller, R.; Freimuth, A.; Lorenz, T. Thermal conductivity, thermopower, and figure of merit of $\mathrm{La}_{1-x} \mathrm{Sr}_{x} \mathrm{CoO}_{3}$. Phys. Rev. B 2005, 72, 155116. [CrossRef]

123. Andrbulakis, J.; Migiakis, P.; Giapintzakis, J. $\mathrm{La}_{0.95} \mathrm{Sr}_{0.05} \mathrm{CoO}_{3}$ : An efficient room-temperature thermoelectric oxide. Appl. Phys. Lett. 2004, 84, 1099-1101. [CrossRef]

124. Zhang, X.; Li, X.M.; Chen, T.L.; Chen, L.D. Thermoelectric and transport properties of $\mathrm{La}_{0.95} \mathrm{Sr}_{0.05} \mathrm{CoO}_{3}$. J. Cryst. Growth 2006, 286, 1-5. [CrossRef]

125. Zhou, A.J.; Zhu, T.J.; Zhao, X.B. Thermoelectric properties of perovskite oxides $\mathrm{La}_{1-\mathrm{x}} \mathrm{Sr}_{\mathrm{x}} \mathrm{CoO}_{3}$ prepared by polymerlized complex method. J. Mater. Sci. 2008, 43, 1520-1524. [CrossRef]

126. He, T.; Chen, J.; Calvarese, T.G.; Subramanian, M.A. Thermoelectric properties of $\mathrm{La}_{1-x} \mathrm{~A}_{x} \mathrm{CoO}_{3}(\mathrm{~A}=\mathrm{Pb}, \mathrm{Na})$. Solid State Sci. 2006, 8, 467-469. [CrossRef]

127. Inagoya, A.; Sawaki, D.; Horiuchi, Y.; Urata, S.; Funahashi, R.; Terasaki, I. Thermoelectric module made of perovskite cobalt oxides with large thermopower. J. Appl. Phys. 2011, 110, 123712. [CrossRef]

128. Kun, R.; Populoh, S.; Karvonen, L.; Gumbert, J.; Weidenkaff, A.; Busse, M. Structural and thermoelectric characterization of $\mathrm{Ba}$ substituted $\mathrm{LaCoO}_{3}$ perovskite-type materials obtained by polymerized gel combustion method. J. Alloys Compd. 2013, 579, 147-155. [CrossRef]

129. Liu, Y.; Li, H.-J.; Zhang, Q.; Li, Y.; Liu, H.-T. Electrical transport and thermoelectric properties of Ni-doped perovskite-type $\mathrm{YCo}_{1-x} \mathrm{Ni}_{x} \mathrm{O}_{3}(0 \leq x \leq 0.07)$ prepared by sol-gel process. Chin. Phys. B 2013, 22, 57201. [CrossRef]

130. Zhou, A.J.; Zhu, T.J.; Zhao, X.B. Thermoelectric properties of perovskite-type oxide $\mathrm{La}_{1-\mathrm{x}} \mathrm{Sr}_{\mathrm{x}} \mathrm{CoO}_{3}(x=0,0.1)$ prepared by solid state reactions. Mater. Sci. Eng. B 2006, 128, 174-178. [CrossRef]

131. Robert, R.; Bocher, L.; Sipos, B.; Döbeli, M.; Weidenkaff, A. Ni-doped cobaltates as potential materials for high temperature solar thermoelectric converters. Prog. Solid State Chem. 2007, 35, 447-455. [CrossRef]

132. Iwasaki, K.; Ito, T.; Nagasaki, T.; Arita, Y.; Yoshino, M.; Matsui, T. Thermoelectric properties of polycrystalline $\mathrm{La}_{1-x} \mathrm{Sr}_{\mathrm{x}} \mathrm{CoO}_{3}$. J. Solid State Chem. 2008, 181, 3145-3150. [CrossRef]

133. Zhou, A.J.; Zhu, T.J.; Zhao, X.B.; Chen, H.Y.; Müller, E. Fabrication and thermoelectric properties of perovskite-type oxide $\mathrm{La}_{1-\mathrm{x}} \mathrm{Sr}_{\mathrm{x}} \mathrm{CoO}_{3}(x=0,0.1)$. J. Alloys Compd. 2008, 449, 105-108. [CrossRef]

134. Mizusaki, J.; Sasamoto, T.; Cannon, W.R.; Bowen, H.K. Electronic Conductivity, Seebeck Coefficient, and Defect Structure of $\mathrm{La}_{1-\mathrm{x}} \mathrm{Sr}_{\mathrm{x}} \mathrm{FeO}_{3}(x=0.1,0.25)$. J. Am. Ceram. Soc. 1983, 66, 247-252. [CrossRef]

135. Nakatsugawa, H.; Saito, M.; Okamoto, Y. High-Temperature Thermoelectric Properties of Perovskite-Type $\mathrm{Pr}_{0.9} \mathrm{Sr}_{0.1} \mathrm{Mn}_{1-\mathrm{x}} \mathrm{Fe}_{\mathrm{x}} \mathrm{O}_{3}(0 \leq x \leq 1)$. J. Electron. Mater. 2017, 46, 3262-3272. [CrossRef]

136. Iijima, M.; Murayama, N. High Temperature Thermoelectric Properties of $\mathrm{La}_{1-x} \mathrm{Sr}_{\mathrm{x}} \mathrm{FeO}_{3}(0<x<1)$. In Proceedings of the 17th Internaltional Conference on Thermoelectrics, Nagoya, Japan, 28 May 1998.

137. Sugahara, T.; Van Nong, N.; Ohtaki, M. Structure and thermoelectric properties of $\mathrm{Ca}_{2-x} \mathrm{Sr}_{\mathrm{x}} \mathrm{FeMoO}_{6}$ $(0 \leq x \leq 0.3)$ double-perovskite oxides. Mater. Chem. Phys. 2012, 133, 630-634. [CrossRef]

138. Sugahara, T.; Araki, T.; Ohtaki, M.; Suganuma, K. Structure and thermoelectric properties of double-perovskite oxides: $\mathrm{Sr}_{2-\mathrm{x}} \mathrm{KFeMoO}_{6}$. J. Ceram. Soc. Jpn. 2012, 120, 211-216. [CrossRef]

139. Sahnoun, O.; Bouhani-Benziane, H.; Sahnoun, M.; Driz, M. Magnetic and thermoelectric properties of ordered double perovskite $\mathrm{Ba}_{2} \mathrm{FeMoO}_{6}$. J. Alloys Compd. 2017, 714, 704-708. [CrossRef]

140. Tak, J.Y.; Choi, S.M.; Seo, W.S.; Cho, H.K. Thermoelectric properties of a doped $\mathrm{LaNiO}_{3}$ perovskite system prepared using a spark-plasma sintering process. Electron. Mater. Lett. 2013, 9, 513-516. [CrossRef]

141. Parkash, O.; Kumar, D.; Srivastav, K.K.; Dwivedi, R.K. Electrical conduction behaviour of cobalt substituted $\mathrm{BaSnO}_{3}$. J. Mater. Sci. 2001, 6, 5805-5810. [CrossRef]

142. Hadjarab, B.; Bouguelia, A.; Trari, M. Synthesis, physical and photo electrochemical characterization of La-doped $\mathrm{SrSnO}_{3}$. J. Phys. Chem. Solids 2007, 68, 1491-1499. [CrossRef]

143. Yasukawa, M.; Kono, T.; Ueda, K.; Yanagi, H.; Wng Kim, S.; Hosono, H. Thermoelectric properties and figure of merit of perovskite-type $\mathrm{Ba}_{1-x} \mathrm{La}_{x} \mathrm{SnO}_{3}$ with $x=0.002-0.008$. Solid State Commun. 2013, 172, 49-53. [CrossRef] 
144. Yasukawa, M.; Ueda, K.; Fujitsu, S.; Hosono, H. Thermoelectric properties and figure of merit of perovskite-type $\mathrm{Sr}_{1-\mathrm{x}} \mathrm{La}_{\mathrm{x}} \mathrm{SnO}_{3}$ ceramics. Ceram. Int. 2017, 43, 9653-9657. [CrossRef]

145. Li, J.; Ma, Z.; Sa, R.; Wu, K. Improved thermoelectric power factor and conversion efficiency of perovskite barium stannate. RSC Adv. 2017, 7, 32703-32709. [CrossRef]

146. Yasukawa, M.; Murayama, N. High-temperature thermoelectric properties of the oxide material: $\mathrm{Ba}_{1-\mathrm{x}} \mathrm{Sr}_{\mathrm{x}} \mathrm{PbO}_{3}(x=0-0.6)$. J. Mater. Sci. Lett. 1997, 16, 1731-1734. [CrossRef]

147. Yasukawa, M.; Murayama, N. A promising oxide material for high-temperature thermoelectric energy conversion: $\mathrm{Ba}_{1-\mathrm{x}} \mathrm{Sr}_{\mathrm{x}} \mathrm{PbO}_{3}$ solid solution system. Mater. Sci. Eng. B 1998, 54, 64-69. [CrossRef]

148. Yasukawa, M.; Kono, T. Bi doping effect on the thermoelectric properties of perovskite-type $\mathrm{Sr}_{0.7} \mathrm{Ba}_{0.3} \mathrm{PbO}_{3}$. Solid State Commun. 2008, 146, 458-461. [CrossRef]

149. Sera, M.; Kondoh, S.; Sato, M. Thermoelectric power of superconducting BaKBiO with Perovskite structure. Solid State Commun. 1988, 68, 647-648. [CrossRef]

150. Yasukawa, M.; Shiga, Y.; Kono, T. Electrical conduction and thermoelectric properties of perovskite-type $\mathrm{BaBi}_{1-\mathrm{x}} \mathrm{Sb}_{\mathrm{x}} \mathrm{O}_{3}$. Solid State Commun. 2012, 152, 964-967. [CrossRef]

151. Kurosaki, K.; Oyama, T.; Muta, H.; Uno, M.; Yamanaka, S. Thermoelectric properties of perovskite type barium molybdate. J. Alloys Compd. 2004, 372, 65-69. [CrossRef]

152. Oba, A.; Kamishima, K.; Kakizaki, K.; Hiratsuka, N. Substitution effect on thermoelectric properties of double Perovskite $\mathrm{Sr}_{2} \mathrm{FeMoO}_{6}$. Trans. Mater. Res. Soc. Jpn. 2012, 37, 267-270. [CrossRef]

153. Maekawa, T.; Kurosaki, K.; Muta, H.; Uno, M.; Yamanaka, S. Thermoelectric properties of perovskite type strontium ruthenium oxide. J. Alloys Compd. 2005, 387, 56-59. [CrossRef]

154. Aguirre, M.H.; Logvinovich, D.; Bocher, L.; Robert, R.; Ebbinghaus, S.G.; Weidenkaff, A. High-temperature thermoelectric properties of $\mathrm{Sr}_{2} \mathrm{RuYO}_{6}$ and $\mathrm{Sr}_{2} \mathrm{RuErO}_{6}$ double perovskites influenced by structure and microstructure. Acta Mater. 2009, 57, 108-115. [CrossRef]

155. Takahashi, R.; Okazaki, R.; Yasui, Y.; Terasaki, I.; Sudayama, T.; Nakao, H.; Yamasaki, Y.; Okamoto, J.; Murakami, Y.; Kitajima, Y. High-temperature thermoelectric properties of the double-perovskite ruthenium oxide $\left(\mathrm{Sr}_{1-\mathrm{x}} \mathrm{La}_{\mathrm{x}}\right)_{2} \mathrm{ErRuO}_{6}$. J. Appl. Phys. 2012, 112, 073714. [CrossRef]

156. Mahmood, A.; Ramay, S.M.; Rafique, H.M.; Al-Zaghayer, Y.; Khan, S.U.-D. First-principles study of electronic, optical and thermoelectric properties in cubic perovskite materials $\operatorname{AgMO}_{3}(\mathrm{M}=\mathrm{V}, \mathrm{Nb}, \mathrm{Ta})$. Mod. Phys. Lett. B 2014, 28, 1450077. [CrossRef]

157. Sakai, A.; Kanno, T.; Yotsuhashi, S.; Adachi, H.; Tokura, Y. Thermoelectric properties of electron-doped $\mathrm{KTaO}_{3}$. Jpn. J. Appl. Phys. 2009, 48, 970021-970024. [CrossRef]

158. Kurosaki, K.; Matsuda, T.; Uno, M.; Kobayashi, S.; Yamanaka, S. Thermoelectric properties of $\mathrm{BaUO}_{3}$. J. Alloys Compd. 2001, 319, 271-275. [CrossRef]

159. Röder-Roith, U.; Rettig, F.; Sahner, K.; Röder, T.; Janek, J.; Moos, R. Perovskite-type proton conductor for novel direct ionic thermoelectric hydrogen sensor. Solid State Ion. 2011, 192, 101-104. [CrossRef]

160. Mettan, X.; Pisoni, R.; Matus, P.; Pisoni, A.; Jaćimović, J.; Náfrádi, B.; Spina, M.; Pavuna, D.; Forró, L.; Horváth, E. Tuning of the Thermoelectric Figure of Merit of $\mathrm{CH}_{3} \mathrm{NH}_{3} \mathrm{MI}_{3}(\mathrm{M}=\mathrm{Pb}, \mathrm{Sn})$ Photovoltaic Perovskites. J. Phys. Chem. C 2015, 119, 11506-11510. [CrossRef]

161. Zhao, T.; Wang, D.; Shuai, Z. Doping optimization of organic-inorganic hybrid perovskite $\mathrm{CH}_{3} \mathrm{NH}_{3} \mathrm{PbI}_{3}$ for high thermoelectric efficiency. Synth. Met. 2017, 225, 108-114. [CrossRef]

162. Guo, S.-D.; Wang, J.-L. Potential thermoelectric materials $\mathrm{CsMI}_{3}(\mathrm{M}=\mathrm{Sn}$ and $\mathrm{Pb})$ in perovskite structures from first-principles calculations. RSC Adv. 2016, 6, 101552-101559. [CrossRef]

163. Poudel, B.; Hao, Q.; Ma, Y.; Lan, Y.; Minnich, A.; Yu, B.; Yan, X.; Wang, D.; Muto, A.; Vashaee, D.; et al. High-Thermoelectric Performance of Nanostructured Bismuth Antimony Telluride Bulk Alloys. Science 2008, 320, 634-638. [CrossRef] [PubMed]

164. Chen, J.; Sun, T.; Sim, D.; Peng, H.; Wang, H.; Fan, S.; Hng, H.H.; Ma, J.; Boey, F.Y.C.; Li, S.; et al. Sb $\mathrm{Sb}_{2}$ Nanoparticles with Enhanced Seebeck Coefficient and Low Thermal Conductivity. Chem. Mater. 2010, 22, 3086-3092. [CrossRef]

165. Sumithra, S.; Takas, N.J.; Misra, D.K.; Nolting, W.M.; Poudeu, P.F.P.; Stokes, K.L. Enhancement in Thermoelectric Figure of Merit in Nanostructured $\mathrm{Bi}_{2} \mathrm{Te}_{3}$ with Semimetal Nanoinclusions. Adv. Energy Mater. 2011, 1, 1141-1147. [CrossRef]

166. Moos, R.; Menesklou, W.; Hardtl, K.H. Hall mobility of undoped n-type conducting strontium titanate single crystals between $19 \mathrm{~K}$ and 1373 K. Appl. Phys. A 1995, 61, 389-395. [CrossRef] 
167. Moos, R.; Härdtl, K.H. Electronic transport properties of $\mathrm{Sr}_{1-\mathrm{x}} \mathrm{La}_{\mathrm{x}} \mathrm{TiO}_{3}$ ceramics. J. Appl. Phys. 1996, 80, 393-400. [CrossRef]

168. Fukuyado, J.; Narikiyo, K.; Akaki, M.; Kuwahara, H.; Okuda, T. Thermoelectric properties of the electron-doped perovskites $\mathrm{Sr}_{1-x} \mathrm{Ca}_{x} \mathrm{Ti}_{1-y} \mathrm{NbyO}_{3}$. Phys. Rev. B 2012, 85, 075112. [CrossRef]

169. Baniecki, J.D.; Ishii, M.; Aso, H.; Kurihara, K.; Ricinschi, D. Density functional theory and experimental study of the electronic structure and transport properties of $\mathrm{La}, \mathrm{V}, \mathrm{Nb}$, and $\mathrm{Ta}$ doped $\mathrm{SrTiO}_{3}$. J. Appl. Phys. 2013, 113, 13701. [CrossRef]

170. Heremans, J.P.; Jovovic, V.; Toberer, E.S.; Saramat, A.; Kurosaki, K.; Charoenphakdee, A.; Yamanaka, S.; Snyder, G.J. Enhancement of thermoelectric efficiency in PbTe by distortion of the electronic density of states. Science 2008, 321, 554-557. [CrossRef] [PubMed]

171. Hsu, K.F.; Loo, S.; Guo, F.; Chen, W.; Dyck, J.S.; Uher, C.; Hogan, T.; Polychroniadis, E.K.; Kanatzidis, M.G. Cubic $\mathrm{AgPb}_{\mathrm{m}} \mathrm{SbTe}_{2+\mathrm{m}}$ : Bulk Thermoelectric Materials with High Figure of Merit. Science 2004, 303, 818-821. [CrossRef] [PubMed]

172. Yu, B.; Zebarjadi, M.; Wang, H.; Lukas, K.; Wang, H.; Wang, D.; Opeil, C.; Dresselhaus, M.; Chen, G.; Ren, Z. Enhancement of Thermoelectric Properties by Modulation-Doping in Silicon Germanium Alloy Nanocomposites. Nano Lett. 2012, 12, 2077-2082. [CrossRef] [PubMed]

173. Dualeh, A.; Gao, P.; Seok, S.I.; Nazeeruddin, M.K.; Grätzel, M. Thermal Behavior of Methylammonium Lead-Trihalide Perovskite Photovoltaic Light Harvesters. Chem. Mater. 2014, 26, 6160-6164. [CrossRef]

(C) 2018 by the authors. Licensee MDPI, Basel, Switzerland. This article is an open access article distributed under the terms and conditions of the Creative Commons Attribution (CC BY) license (http://creativecommons.org/licenses/by/4.0/). 